\title{
TAU MAI E KAPITI TE WHARE WANANGA O IA, O TE NUI, O TE WEHI, O TE TOA: RECLAIMING EARLY RAUKAWA-TOARANGATIRA WRITING FROM OTAKI
}

\section{BY}

\section{ARINI MAY LOADER}

\author{
A thesis submitted to \\ Victoria University of Wellington \\ in fulfilment of the requirements for the degree of \\ Doctor of Philosophy in Maori Studies
}




\section{Contents}

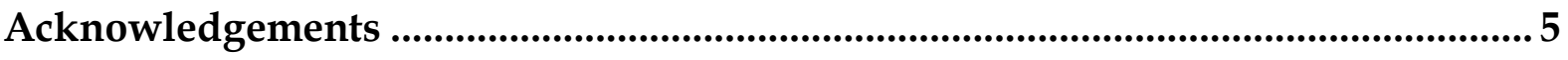

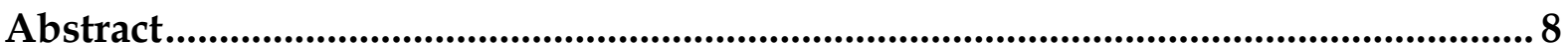

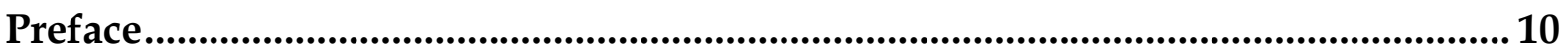

Orthographic conventions ..................................................................................... 10

A note on terminology ………................................................................................ 12

A note on referencing......................................................................................................13

A note on the names of tupuna............................................................................ 14

INTRODUCTION: Tau mai e Kapiti .........................................................................16

The order of the sections and chapters ............................................................................ 19

The order of the sections............................................................................................ 21

The order of the chapters .................................................................................... 22

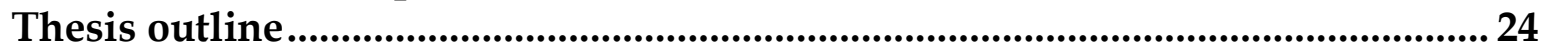

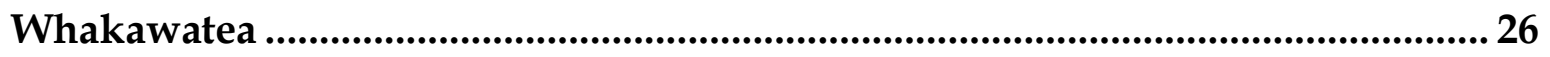

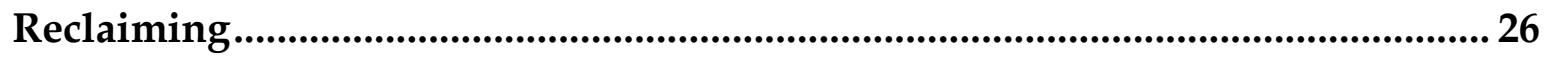

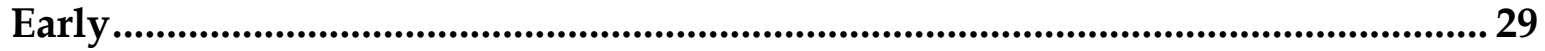

Raukawa - Toarangatira.............................................................................................. 30

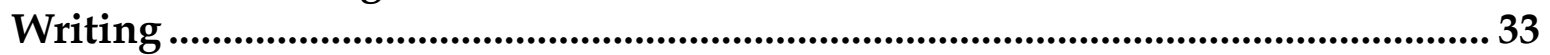

Otaki .......................................................................................................................... 37

George Grey and Maori manuscripts................................................................................ 41

The treatment of Maori-language quotes in this thesis............................................. 51

POU TUATAHI: SECTION ONE................................................................................... 52

Chapter One: The invention of history: The history of Tamihana

Te Rauparaha's 'History of Te Rauparaha' ................................................................52

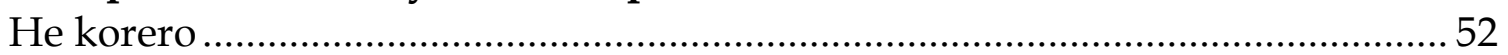

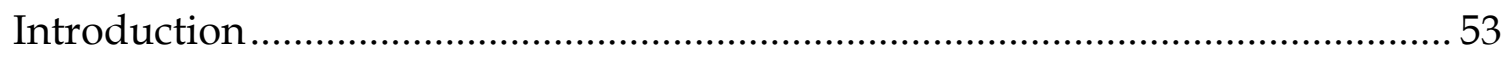

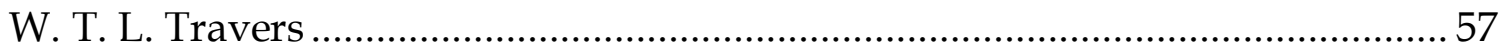

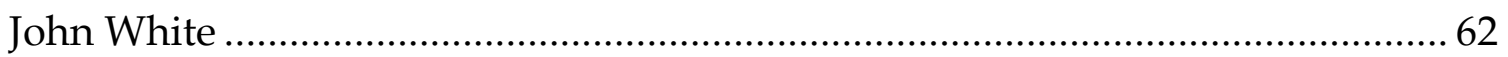

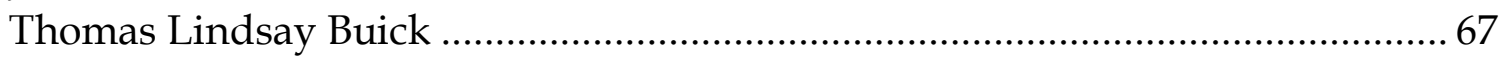

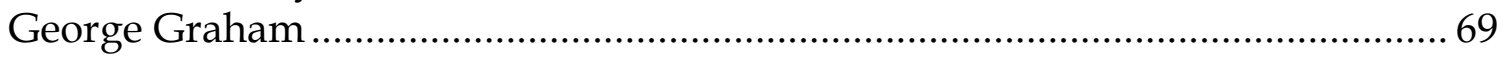

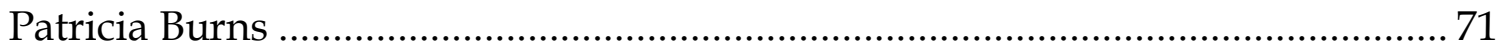

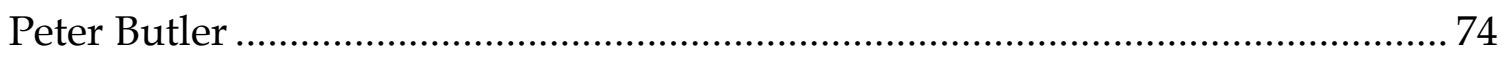

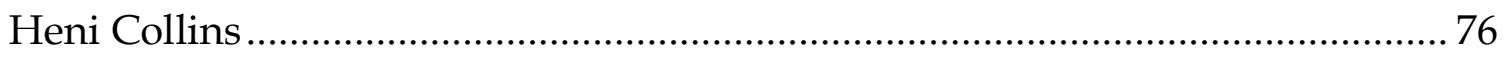

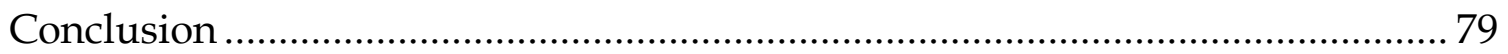

Chapter Two: Reading Tamihana Te Rauparaha .................................................... 80

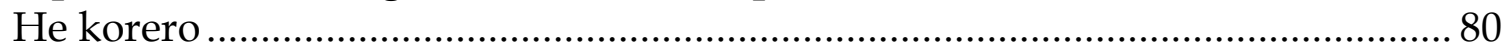

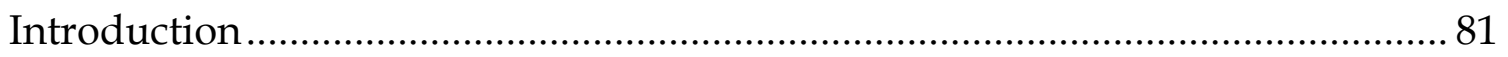

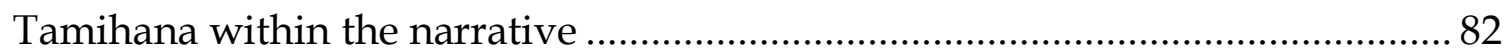

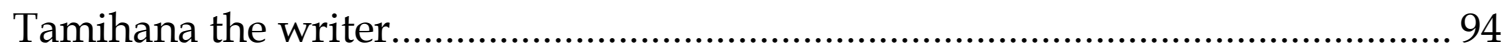

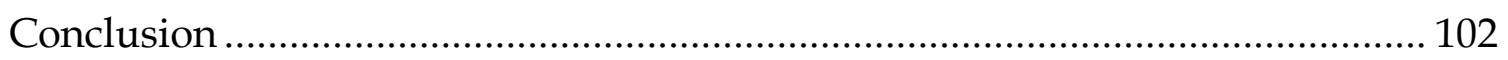




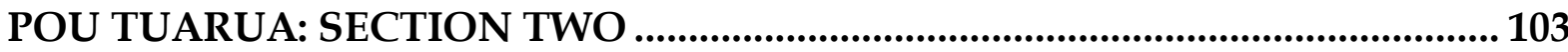

Chapter Three: The invention of mythology: Sir George Grey's Ko nga Mahinga

a nga Tupuna Maori and Polynesian Mythology ....................................................... 103

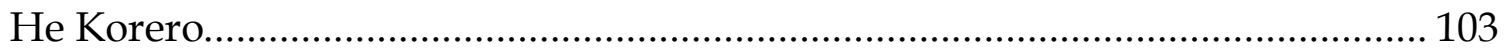

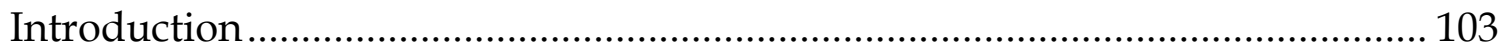

Nga Mahinga and Polynesian Mythology ………………..................................... 107

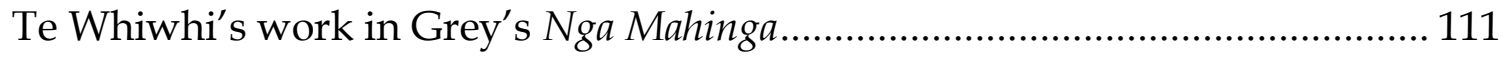

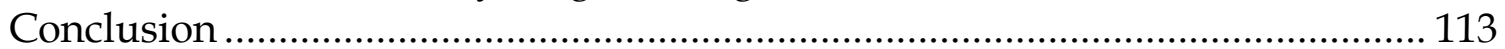

Chapter Four: Reading whakapapa in Matene Te Whiwhi's 'Ko te korero tenei o

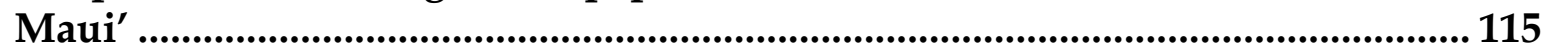

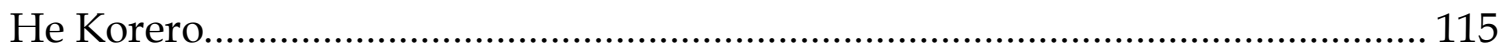

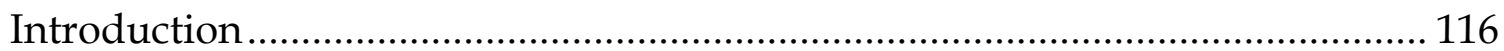

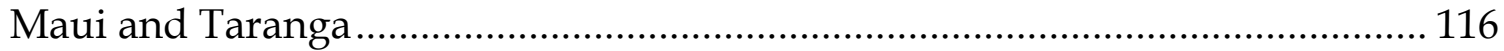

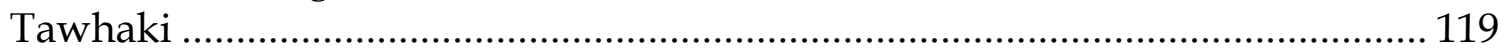

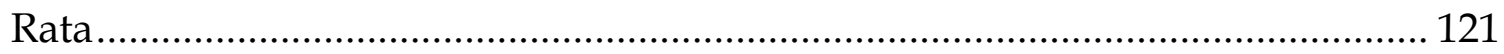

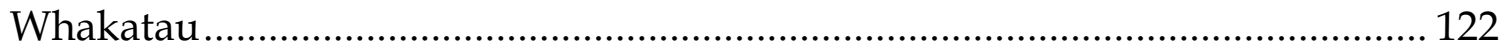

Hineteiwaiwa, Tinirau and Tuhuruhuru .......................................................... 124

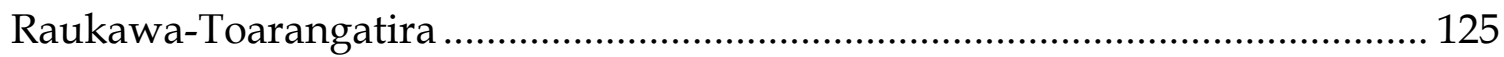

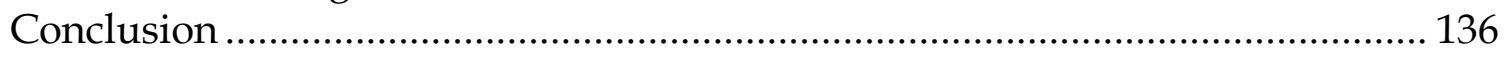

POU TUATORU: SECTION THREE....................................................................... 138

Chapter Five: Reading tribalscape in two tangi composed by Rakapa Kahoki 138

He Korero.............................................................................................. 138

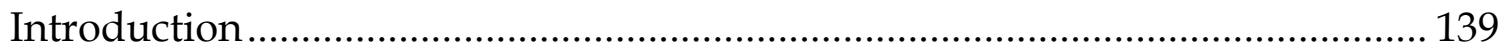

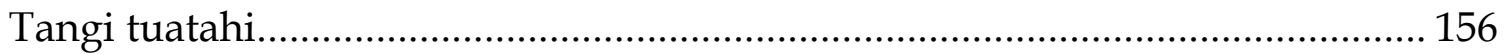

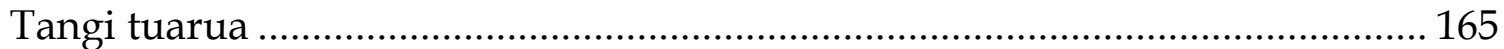

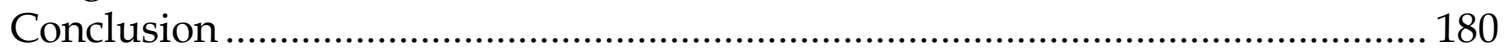

CONCLUSION: E noho ana au i te koko o toku whare ………………………....... 181

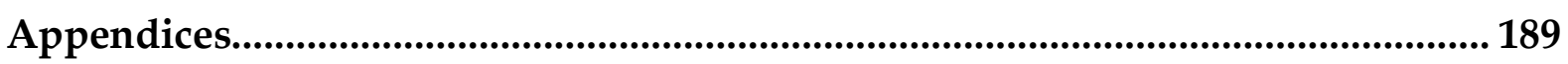

Tangi tuatahi na Rakapa Kahoki ............................................................................... 189

Tangi tuarua na Rakapa Kahoki ....................................................................... 190

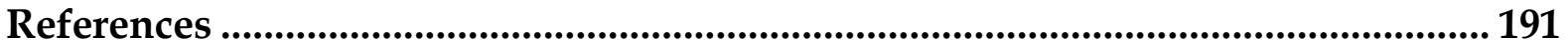




\section{List of illustrations}

Photograph 1: The front cover of Tamihana Te Rauparaha's manuscript. 101

Photograph 2: Rakapa Kahoki's first tangi for Te Rangitopeora as it appears in Tamihana Te Rauparaha's manuscript

Photograph 3: Rakapa Kahoki's second tangi for Te Rangitopeora as it appears in

Tamihana Te Rauparaha's manuscript 


\section{Acknowledgements}

I owe a debt of gratitude to the people who helped me before my $\mathrm{PhD}$ journey officially began. My MA supervisor, Alice Te Punga Somerville, encouraged me to think about PhD study before I had even submitted by MA for marking. She said at the time that the idea of doing a PhD would sound crazy (which it did) but she quietly persisted until I was ready to heed her advice and follow her on another journey into what was, at least for me, the intellectual unknown. My heart-felt thanks goes to you, e hoa, for the unwavering faith you placed in me and my abilities, for all your words of wisdom, your expert guidance and mentoring.

Rawinia Higgins has also been a constant supporter of my work and has showed me the exciting possibilities and opportunities which open up when you pursue your interests and follow your instincts. Ra, you have deeply challenged and inspired me in your singularly thoughtful and considered way. Ever the voice of reason, you extended my thinking in a myriad of directions as you rode the ups and downs of this project alongside me. Your generosity knows no bounds and I am eternally grateful for all the time you spent with me patiently exploring and developing ideas and helping me negotiate the challenges of $\mathrm{PhD}$ study.

Both of these amazing wahine guided me through minefields of critical theory and periods of intense confusion and frustration. My dream-team of supervisors saved me when my writing tongue was tied and were always armed with a fresh new metaphor which enabled me to 'write through' the issues. Alice and Ra were understanding and supportive of my other commitments to my whanau and community and also took the time to ensure that my working on this thesis was financially viable. This thesis could not have been completed without the help of these two incredible intellectuals. E kore e mutu nga mihi ki a korua.

I would also like to acknowledge the generous financial support I received from a number of sources which enabled the successful completion of this thesis. The award of a Victoria University Vice-Chancellor's Strategic PhD Research Scholarship provided the financial backbone for this work and a Victoria University 
Toihuarewa $\mathrm{PhD}$ completion scholarship provided financial support during the critical final stages of the thesis. I also received a postgraduate scholarship from the Ngati Whakaue Education Endowment Trust Board and a Queen Elizabeth II postgraduate award administered by the Maori Education Trust. I was a recipient of a Postgraduate Research Excellence Award from the Post Graduate Students' Association of Victoria University of Wellington which enabled me to present a paper at a conference on the international stage at the Native American and Indigenous Studies Association (NAISA) annual meeting (Sacramento, May 2011).

Special thanks also to Paul Meredith and Piri Sciascia of the Pro-Vice Chancellor Maori office at Victoria University of Wellington for financial support, encouragement and leadership. I would also like to extend my thanks to Te Whanau o Te Kawa a Maui the School of Maori Studies at Victoria University of Wellington. This work benefitted from numerous conversations, debates and other interactions with staff members, fellow PhD candidates, researchers and students. Te Whanau o Te Herenga Waka have also supported my study from my first year as an undergraduate student. Thanks especially to whaea Te Ripowai, whaea Noti, Grandma, Tu, Matu, Mana and especially Grandpa Pita Samuel who made me feel so welcome when I first arrived at Victoria. Nga mihi nui ki a koutou katoa.

Thanks also to MANUAO for holding writing retreats, write-on-site sessions and seminars and most especially to Meegan Hall who works so hard for Maori staff and students at Victoria but remains one of the most humble people I know. The MAI ki Poneke group were also instrumental in providing opportunities to write, whanaunatanga and most importantly, a never-ending supply of tiakareti. Kei te mihi, kei te mihi. Also, to Ewan, Mike and Dion of 'Ewan's writing group', friends in writing and the struggle towards $\mathrm{PhD}$ completion. Kia kaha e hoa ma.

Thank you to all the librarians who helped me locate key texts and poured over them with me especially Robert Eruera at Auckland Public Library.

I would like to acknowledge Te Pouhere Korero, the Maori Historians group for the wananga, the whanaungatanga, and so many memorable moments in Maori history. Thanks especially to Aroha Harris who remains a steadfast supporter of my 
research endeavours and my whanaunga Rewa Morgan who gives up so much of her time to talk history, whanau and whakapapa with me.

To Mom and Dad. This work would never have even begun were it not for your deep spring of aroha for your whanau. My heartfelt thanks for all the babysitting, the comic relief and the grounding in reality. This work is dedicated to my biggest motivations and inspirations, oku tino taonga, Tahiwi and Hineteaio. 


\section{Abstract}

Maori writing in the nineteenth-century was prolific. Maori writers worked in multiple genres including, but not limited to biography, correspondence, historical narrative, political response, memoir and song composition. Much of this immense body of work is currently housed in libraries and other archival institutions around Aotearoa New Zealand. An indeterminate amount is held in private ownership. Of the small number of these manuscripts which have been published, many have gone on to become key texts for studying Maori language, customs, practices, beliefs, and history. Responding to the calls of Australian and American Indian literary studies for researchers to engage both critically and creatively with Indigenous literatures, this thesis will focus on specific nineteenth-century Maori literary works in order to explore the nature and stakes of early Maori writing. The impact of European contact which informed many nineteenth-century Indigenous experiences will be interrogated as will the substantial manuscript and archival records that assist us, the descendants of these writers, in reclaiming our written heritage.

Specifically, this thesis will explore a small selection of the written legacies of Tamihana Te Rauparaha, Matene Te Whiwhi and Rakapa Kahoki. These tupuna wrote letters, petitions and historical texts, acted as scribes and composed waiata. As well as sharing close Ngati Raukawa and Ngati Toarangatira whakapapa and moving in similar social and political circles, these tupuna were based in Otaki where they were actively involved in issues of local, tribal and national significance. Focusing this thesis on the specific place of Otaki provides an opportunity to reflect on the nature and significance of Maori writing more broadly and also anchors this thesis in ancestral space. An academic revisioning of these ancestors' written work is long overdue and is especially timely while Indigenous peoples continue to be engaged in projects of intellectual recovery and reclamation.

This thesis presents readings of several manuscripts that were produced by Tamihana Te Rauparaha and Matene Te Whiwhi as well as two waiata texts composed by Rakapa Kahoki relatively early on in our encounters with tauiwi and 
the written word. Where many historically based studies have made use of these manuscripts as source documents, this research instead offers a literary exploration of the manuscripts which sees the manuscripts themselves as the main point of reference. This thesis essentially draws attention to the 'written-ness' of the texts. It is a literary study which highlights the literary skills that our ancestors employed in their written work and which have tended to be overlooked in the scholarship. This study is also influenced by developments in a number of academic fields including but not limited to history, linguistics, Pacific studies, comparative studies and postcolonial studies. It is moreover, a Maori studies thesis which centres a Maori world view and the concerns of Maori people and communities.

Ultimately, it is anticipated that this thesis will forge new pathways into the study of Maori literatures, and that these pathways will clear some much needed intellectual space in which a deeper analysis of the writing of tupuna Maori can be articulated. Furthermore, beyond its focus on the literature of Ngati Raukawa and Ngati Toarangatira, this thesis extends the scholarship on Maori writing and literatures, Maori historical studies and Maori intellectual history and in this way speaks to a contemporary Indigenous intellectual agenda. 


\section{Preface}

\section{Orthographic conventions}

Maori words and phrases in the main body of the text appear without macrons or double vowels to indicate vowel length. My main reasons for taking this stance concern consistency and ambiguities in vowel length. For example, while it is generally agreed that the word 'Maori' has a long 'a' vowel and following the guidelines set by Te Taura Whiri i te reo Maori/The Maori Language Commission should be written using a macron (ie 'Māori'), place and personal names are more contentious and a range of pronunciations and preferred spellings for any one name may currently be in use. For example, the Kapiti Coast District Council has added a macron to the ' $a$ ' in 'Kapiti' ${ }^{1}$ but the same name appears without a macron on Te Ara, the online encyclopedia of New Zealand. ${ }^{2}$ While the meaning of a Maori word can change depending on whether a vowel is long or short, context usually provides enough information to avoid misunderstandings or confusion. Where macrons appear in direct quotes they are retained in order to maintain the integrity of the source text and the preferences of the writers, editors and publishers who produced these works.

Words and phrases in the Maori language are not italicised. Marking words and phrases which originate from the Maori language as being 'foreign' to New Zealand English is unnecessary and does not reflect the linguistic reality which has seen New Zealand English absorb increasing amounts of Maori words into its lexicon. Further, Maori language quotes are not glossed with English language translations or interpretations. Discussion surrounding quotes in the Maori language provides enough context for non-Maori speakers to comprehend the ideas conveyed and to ascertain key points. Where quotes appear in the source publication in both languages, both the Maori and English language versions are included not least due to one not always being a close translation of the other.

\footnotetext{
1 http://www.kapiticoast.govt.nz/.

${ }^{2}$ http://www.teara.govt.nz/en/wellington-places/page-15.
} 
It is useful to draw on perspectives from the discipline of comparative literature when discussing the language interface between English and Maori in this thesis which works with Tamihana Te Rauparaha and Matene Te Whiwhi's texts in their original language, but uses another language to do the critical work on them. The discipline of comparative literature shows us that it is not necessary to work in translation when working with texts across languages and that rather than labouring under translation one language must necessarily be used to write "across" the languages of the texts being studied (Bernheimer 1995, Saussy 2006). Furthermore, both the language of the texts being studied and the language employed in the critical work of this thesis intercept and interact at multiple junctions in often surprising ways that facilitate a complementary relationship. The ultimate result of this language interplay is that readers who have good knowledge of both the Maori language and the English language will enjoy a richer and more nuanced reading of this work than those whose expertise is limited to either one or the other (abridged from Loader 2008: 24).

Direct quotations from the manuscripts also appear without macrons or double vowels to indicate long vowels for the reasons stated above and additionally in keeping with the orthographic conventions employed by the writers of the manuscripts. The exclusion of macrons from these texts did not inhibit nineteenthcentury readers as evidenced by the masses of material written in the Maori language from this era nearly all of which appears without macrons or double vowels marking long vowels. Direct quotes from the manuscripts appear as closely to the originals as legibility and sense allows. Line length is retained, and other features of the writing such as the running together of two words which are now commonly written as separate words are retained so as to give the reader a sense of how the original documents read. Quotes from the manuscripts appear without the use of [sic] due to the presence of this marker interrupting the flow of the writing.

Tamihana Te Rauparaha had what has been called by one writer "a number of unusual spelling habits" particularly concerning his use of the letter ' $h$ ' immediately following the letter ' $w$ ' (Collins 2010: 9). For example, Tamihana consistently writes 
the place name that is commonly today spelt 'Wairarapa' as 'Whairarapa' (Te Rauparaha 18?: 9) and the word 'iwi' as 'iwhi' (Te Rauparaha 18?: 8). Tamihana Te Rauparaha's spellings of such words are reproduced in this thesis as they appear in the original due to their being internally consistent and therefore not posing a problem in terms of understanding the text. This is done out of respect for and in keeping with the orthographic conventions employed by the writer of the text and in order that the reproducing of the texts in as close a way as possible to the original documents will inspire further research on them to be undertaken.

The Ngati Toarangatira tribe is often referred to simply as Ngati Toa. In a further variation, Te Runanga o Ngati Toa Rangatira, the mandated iwi authority and administrative body of iwi estates and assets, writes 'Toa' and 'Rangatira' separately. For the sake of consistency all references to Ngati Toarangatira in the main body of the text are written in the long version of the name in two words as in 'Ngati Toarangatira'. Where the shortened version 'Ngati Toa' appears in direct quotes it is retained.

\section{A note on terminology}

The use of the term 'Raukawa-Toarangatira' throughout this thesis is indicative of the close relationship that the peoples of Ngati Raukawa and Ngati Toarangatira share. The seeds of this relationship are sown in our shared whakapapa from the Tainui waka and continue through a complex web of subsequent socio-political alliances. This relationship is consolidated by our land-based associations including the series of joint migrations that many Raukawa, Toarangatira and Te Ati Awa peoples undertook to the Ika a Maui/Tau Ihu area in the early nineteenth-century. The ART (Ati Awa-Raukawa- Toarangatira) confederation of tribes around which much modern discourse focuses is not the concern of this thesis. The intention is not to exclude in any way the peoples of Te Ati Awa but rather to centre this thesis in the geographic space of Otaki and the literature of Tamihana Te Rauparaha, Matene 
Te Whiwhi and Rakapa Kahoki and thus within what can be termed a RaukawaToarangatira intellectual tradition.

\section{A note on referencing}

While a note written onto Matene Te Whiwhi's manuscript in Sir George Grey's hand gives the date of the manuscript as 1852, the chronological dating according to a Gregorian or Julian calendar of Tamihana Te Rauparaha's manuscript is far from clear. Dates given for this manuscript range from 1845-1849 and appear to derive from two sources within the manuscript itself. The first of these sources appears at the very end of the manuscript on page 127 where the text reads, 'Na Te Whakarauihi Nohorua enei whakapapa i whakahaere, Naku i tuhituhi i te $1845^{\prime}$. This statement refers to the whakapapa listed at the end of the manuscript but seems to have been taken by some researchers to be an indication of the provenance of the manuscript. The second source is found at the beginning of the manuscript on the first of the two images pasted into the front cover: the image on the left shows a photograph of a drawing of Te Rauparaha and the image on the right is a studio portrait of Tamihana Te Rauparaha and his wife Ruta. Underneath the image of Te Rauparaha and written in what appears to be Tamihana Te Rauparaha's hand is the caption 'Te Rauparaha kua mate Noema 27 1849'. This caption gives the date of Te Rauparaha's death as 27 November 1849. While it is possible that the manuscript was written at the end of November 1849 it could not have been written in 1845 due to the manuscript including details of Te Rauparaha's death. However, neither of these dates found on the manuscript actually state the date that the manuscript was written. The cataloguing system for the George Grey Special Collections used by Auckland Public Library uses the letters GNZMMSS followed by a numeral. GNZMMSS stands for 'Grey New Zealand Maori Manuscripts'. These labels are unsatisfactory as they ignore the writers of the manuscripts and draw unnecessary attention to the collector. In this thesis, citations for GNZMMSS 46, or Matene Te Whiwhi's 'Genealogies and legends' appear as (Te Whiwhi 1852: ) followed by 
the page number and therefore follow the expected convention. However, citations for GNZMMSS 27, or, Tamihana Te Rauparaha's 'History of Te Rauparaha written by his son Tamehana Te Rauparaha at his fathers dictation', appear as (Te Rauparaha 18?: ) followed by the page number. I assigned page numbers to this manuscript due to the original text being unpaginated. The pages of Tamihana Te Rauparaha's manuscript upon which the words of Rakapa Kahoki's waiata are written remain unpaginated but pose no major problems due to these being a single leaf inserted into the beginning of Tamihana Te Rauparaha's manuscript. ${ }^{3}$

\section{A note on the names of tupuna}

The tupuna upon whose written and composed work this thesis is based are known by a variety of names. The tupuna most commonly referred to today as Tamihana Te Rauparaha, for example, was known as Katu prior to his Christian baptism in 1841 whereupon he took the name Tamihana (Thompson) (Oliver 1990b: 507). Throughout this thesis Tamihana Te Rauparaha is referred to most often simply as Tamihana. This is done for reasons of expediency and so as not to confuse him with his father, Te Rauparaha. Tamihana's cousin, Henare Matene Te Whiwhi-o-te-rangi, is commonly remembered today as Matene Te Whiwhi. Te Whiwhi took the names Henare and Matene, after Henry Martyn, a notable missionary to India, upon his Christian baptism in 1843 (Oliver 1990: 528). For reasons again of expediency, I refer to him simply as Te Whiwhi throughout the greater part of this thesis. Rakapa Kahoki, Te Whiwhi's sister, tends to be remembered by either one or both of her

\footnotetext{
${ }^{3}$ In their online catalogue Auckland City Libraries gives the date of Matene Te Whiwhi's 'Genealogies and Legends' as 1852 and Tamihana Te Rauparaha's 'History of Te Rauparaha written by his son Tamihana Te Rauparaha at his father's dictation' as 1849. Kerr notes that Grey received two manuscripts from Matene Te Whiwhi in the early 1850s and goes on to say that the first forty-six pages were written, according to Grey's notes, at Otaki and Poroutawhao in 1852 while the last thirteen leaves were dictated in April 1851 (2006: 80). Kerr also states that Tamihana Te Rauparaha wrote his account about his father's life 'about 1845' (2006: 80). Simmons states that Te Whiwhi's manuscript is dated to 1852 (1966: 181).
} 
names. I follow the example set by Apirana Ngata in his Nga Moteatea and refer to her as Kahoki in most instances. ${ }^{4}$

4 See Ngata 1972: 186-187; 262-263. 


\section{INTRODUCTION: Tau mai e Kapiti}

My great grandfather, Kingi Rawiri Te Ahoaho Tahiwi, was the eldest child of Keita Koa (Kapu Meaha) and Rawiri Rota Tahiwi. He made a career as a translator, was a Maori rugby stalwart and played the piano and the banjo. In 1936 he founded the Ngati Poneke Young Maori Club in Wellington, the first and longest running Maori cultural club. Club nights are still held every Monday at Pipitea marae and several generations of family members continue to be actively involved in the Club. In addition to teaching and leading in the choir and kapa haka activities of Ngati Poneke, Koro Kingi was a prolific composer. Many of these compositions, known as 'ditties', were sung to the tunes of popular songs of the day. Aue Ringaringa Pakia, for example, was sung to the tune of Happy Days Are Here Again. Koro Kingi's repertoire ranged from light-hearted and entertaining waiata-a-ringa to such sweet yet poignant love songs as Mapu Kau. Koro Kingi also composed waiata which expressed his feelings in relation to more specific events. In E Whiti Te Marama for example, Koro Kingi laments his daughter's absence while she is away teaching at Omaio School in the Bay of Plenty.

One of Koro Kingi's more serious compositions, Tau Mai E Kapiti, is a waiata moteatea which tells of the history of our connection to Kapiti Island:

Tau mai e Kapiti

te kainga o te hunga kua wehe ki te iwi nui i te po

Te marae i Wai-o-rua tenei te mihia,

te wahi i tanuku ai te whakaaro o te motu,

kia patua o tamariki i kopainga e koe.

Hei tohu kinga uri whakaheke mai

i te mana o tuawhakarere iho

$i$ te mana $i$ te wehi o Io nui...i

Tau mai e Kapiti

Te Whare Wananga o ia, o te nui, o te wehi, o te Toa.

Whakakaupapa i te nohotahi, a Awa, a Toa, a Raukawa.

I heke mai i Kawhia ki te kawe tikanga 
hei ora mo nga uri o muri nei.

Tau mai e Kapiti te kainga tupu

o te wehi, o te toa, o te whakamanawanui...i

\section{Tau mai e Kapiti}

Te kainga o te kino, o te mau-a-hara, o te kaitangata

e ai ra hoki ki nga kupu whakapae o nga iwi maha o te motu nei.

Ko Rangatira te marae tenei te mihia,

tona rite he marae paenga whakairo,

ki roto o Kaiweka, he marae rongonui

ki runga ki raro tawhio noa... a

\section{Tau mai e Kapiti}

Whakataretare mai ki te rangatahi e hao nei.

Waikahua, Waikatohu, e mau ki nga mana i ngakia e koe.

Uhia mai ra te manaakitanga a nga tupuna kua wehe ki te po

hei mauri whakakaha i te hinengaro

o Tama, o Hine e pae nei. ${ }^{5}$

Koro Kingi composed this waiata in the 1930s, some 30 or so years after the Kapiti Island Public Reserve Act (1897) was introduced to Parliament by Prime Minister Richard Seddon. This Act declared Kapiti a public reserve, vesting in the Crown those parts of the island, amounting to about 750 acres, held by individuals other than 'the original owners', and prohibited all private dealing in Kapiti land. ${ }^{6}$ By 1904 the Crown had acquired around 3,000 acres of the estimated 4,990 acres on the island, leaving some 1,620 acres in the hand of 'the original owners'.7 Subsequent sections were purchased on the island up until 1965. ${ }^{8}$ Today tangata whenua have managed to retain the possession of 32.5 acres around Waiorua Bay. ${ }^{9}$

\footnotetext{
${ }^{5}$ The layout and punctuation of the waiata follows Royal (1994: 88-93) with the exception of macrons being left off.

${ }^{6}$ Anderson and Pickens (1996: 326).

${ }^{7}$ Anderson and Pickens (1996: 326).

8 Anderson and Pickens (1996: 327). In the 2007 documentary Kapiti Hono Tatai Hono, John Barrett notes that while Pakeha owners were forced to relinquish their interests in the island, Maori owners were pressured but not forced. He notes that Utauta Webber, the daughter of Wi Parata Te Kakakura, absolutely refused to give up her interests.

${ }^{9}$ http://kapitiislandnaturetours.co.nz/the-island/history/.
} 
The alienation of Kapiti has long been and remains an issue of contention between my people and the Crown. ${ }^{10}$ A political message is 'clothed'11 in the third line of the final verse, 'Waikahua, Waikatohu, e mau ki nga mana i ngakia e koe'. This line ponders the future of Kapiti and asks in whose control and authority Kapiti will be vested. Although these words apply locally to Kapiti, the same question can be asked all over the country. This question posed by Koro Kingi points to the central issue of te mana o te whenua. Koro Kingi's moteatea is still sung today and it keeps our collective feelings of belonging to Kapiti alive and passes these sentiments and the history on to our tamariki mokopuna.

In 2013 Kapiti is a picturesque blend of bush and birdsong. Kakariki dart in and out of the low, regenerating forest canopy and pukeko and weka roam freely. Kapiti forms an impressive figure of lush vegetation against the wild seascape of the south-west coast of Te Ika a Maui and remains to this day a wildlife sanctuary and haven for threatened native species. Kapiti is also, as Koro Kingi's waiata alludes to, a sanctuary of korero, of the histories and stories that are attached to its place names and of the memories that are carved into its physical presence. The manuscripts that are explored in this thesis are similarly protected in their own sanctuary, in the special collections of Auckland Public Library. Like the visitors who come to view the wildlife that has made Kapiti its home, the manuscripts are visited by keen individuals who come especially to view them in their restricted environment. The manuscripts are contained within temperature-controlled vaults and are so preserved for future generations of students, scholars and interested others who wish to view them and learn something of their shape and meaning.

An additional dimension brings the people who whakapapa to Kapiti 'home again'. Wananga whakapapa draws those who have genealogical links to the island 'home' to experience a special part of their heritage and to enjoy the different perspectives that such experiences provide. So too do wananga whakapapa bring descendants of the writers to the libraries and other archival institutions which hold the written taonga of their tupuna. The repeated refrain Tau mai e Kapiti reminds us that our first step is to literally Land on the

\footnotetext{
${ }^{10}$ Historian Chris Maclean notes that in 1996 while the Department of Conservation planned to celebrate the approaching centenary of Kapiti Island as a bird sanctuary, local iwi soon made it clear that some reconsideration was required (1999: 11). Matiu Rei, the chief executive of Ngati Toarangatira, commented, 'This is 100 years of eviction, not celebration' (Maclean 1999: 11). 11 This recalls Ngata who wrote that, 'In former times a wealth of meaning was clothed within a word or two as delectable as a proverb in its poetical form and in its musical sound' (1972: xv).
} 
space that is Kapiti. Like the manuscripts explored in this thesis, one first has to take oneself to them to engage with them and to experience them in their own particular context. As I move into the thesis proper I invite readers to land and settle on to a different space and to so experience the perspectives and views offered in this thesis.

\section{The order of the sections and chapters}

The overall structure of this thesis is inspired by one of the most prominent physical embodiments of Maori culture and identity, the whare whakairo. ${ }^{12}$ I follow the lead of several Maori scholars who also used whare whakairo as a method of structuring their theses. In his 1991 MA thesis, "Te Ahua o te Kupu Whakaari: The Nature of Prophetic Sayings", Pou Temara names the chapters of his thesis after structural and decorative features of wharenui including the tahu, the heke, the poupou and the poutokomanawa (1991: 21-25). Temara tells us that he uses specifically Tuhoe names for several features of the wharenui, namely the pou te wharau and the pou te rangianiwaniwa (1991: 21-22). The use of these names centres his uniquely Tuhoe tribal perspective. Temara furthermore links the form of the wharenui to Tuhoe oratory and explains that if there are four speakers on the pae, the role of the first speaker is to establish the tahu, the role of the second speaker is to construct the heke, the role of the third speaker is to erect the poupou and the paetara and to construct the roof and the role of the fourth and final speaker is to bind all the speeches together (1991: 20). This connection between the structuring of formal oratory and the structure of wharenui provides a template for how a thesis, a formal piece of writing, can similarly be meaningfully structured.

Takirirangi Smith also constructs what he calls "a theoretical carved wharenui" in his 2007 PhD thesis, "Whakapapa Korero, Tangata Whenua and

\footnotetext{
12 Whare whakairo are also known by other names such as 'wharenui', 'whare runanga', 'wharepuni', 'wharehui' and 'whare tupuna' (Higgins and Moorfield 2004: 74). These names highlight different ways in which the house might be conceptualised or used. 'Whare runanga', for example, can be translated into English as 'council house' and 'wharepuni' as 'sleeping house' whilst 'wharenui' simply means 'large house'. I chose to use the name 'whare whakairo' for my frame in this thesis due to the connections between carving, korero, knowledge and representation.
} 
Turangawaewae: A Case Study of the Colonisation of Indigenous Knowledge". In his thesis Smith explores the colonisation of indigenous knowledge through close examination of tribal manuscript texts. Smith also brings a particularly personal perspective to his use of the analogy which is informed by his being a tohunga whakairo, a master carver. Throughout the course of his thesis Smith takes readers through the processes involved in constructing a wharenui, from preparing the site to erecting the tahu, the poupou and other key features of the wharenui. Like Temara, Smith names his thesis chapters after prominent features of the wharenui. Smith also names chapters of his thesis after the processes involved in the construction of a carved wharenui.

The decision to use the form of the whare whakairo as the structural foundation of this thesis also takes much inspiration from an article written by Maori scholar, musician and poet the late Hirini Melbourne entitled, "Whare whakairo: Māori 'literary' traditions" (1991). In his article, Melbourne uses the analogy of the whare whakairo to articulate a framework for conceptualising Maori literary traditions. Melbourne writes:

The whare whakairo is a symbol of cultural unity, a place of shelter and peace. It is a place where knowledge is stored and transmitted and where the links with one's past are made tangible. The whare whakairo is a...complex image of the essential continuity between the past and present that indicates how contemporary writing in the Māori language might express the world of the Māori people (1991: 133).

Melbourne highlights the whare whakairo as the realm of Rongo, a realm of peace and shelter which is also a repository of knowledge and a space where knowledge is transmitted. In his ohaki to Te Whanau o Te Herenga Waka, the whanau of the marae at Victoria University of Wellington, the late Ruka Te Rangiahuta Broughton refers to the whare whakairo of the marae, Te Tumu Herenga Waka, as "te pataka kai iringa hoki o te kupu o te korero a te kahui kahika o nga ra ki tua". Broughton's poetic analogy accentuates the wealth of histories, stories and knowledge that is contained in the whare whakairo and the intellectual legacy that our tupuna have left us in their architecture and art. 
The tahu or main kaupapa of the whare whakairo that I construct in this thesis is Early Raukawa-Toarangatira Writing from Otaki. The heke or ribs which descend down from the tahu are the texts that our tupuna composed. The poupou in this whare whakairo, the ancestors barely out of lived memory whose work is examined in this thesis, are Tamihana Te Rauparaha, Matene Te Whiwhi and Rakapa Kahoki.

\section{The order of the sections}

Tamihana Te Rauparaha's text about the life of his father is dealt with in the first section of this thesis in order to deal directly with the looming historical figure of Te Rauparaha. The influence of this great nineteenth-century rangatira runs the length and breadth of this thesis as it similarly does over nineteenth-century Aotearoa New Zealand history. ${ }^{13}$ Placing the section that deals with Tamihana Te Rauparaha's manuscript about Te Rauparaha in this initial position functions as a whakawatea of sorts which clears some space and prepares the ground for the other discussions to come beyond those which focus directly on Te Rauparaha.

The chapters which explore the writing of Matene Te Whiwhi are placed second due to both Tamihana and Te Whiwhi being influential and important leaders of their time and due also to their having shared so much life experience. These closely related contemporaries were born into the rangatira classes of Ngati Raukawa and Ngati Toarangatira, they both learnt to read and write, attended St John's College in Auckland, converted to Christianity and mixed in similar circles. Indeed, their close association is suggested by their manuscripts studied in this thesis in which both tupuna feature in the whakapapa lists written by the other. ${ }^{14}$

\footnotetext{
13 See Ballara (2003: 33-35) for a compelling argument in regards to the prominence of Te Rauparaha and Hongi Hika in the historiography.

${ }^{14}$ Te Whiwhi appears on page 125 of Tamihana's manuscript and is mentioned on page 113 where Tamihana writes about their journey to Te Waipounamu to preach (Te Rauparaha 18?). Tamihana is written into Te Whiwhi's whakapapa on pages 47 and 49 (Te Whiwhi 1852).
} 
The focus on Rakapa Kahoki's compositions in the final section brings the thesis full circle and necessitates a return to Tamihana Te Rauparaha's manuscript. The words of Rakapa Kahoki's tangi are written in Tamihana Te Rauparaha's hand and are bound into the opening pages of his manuscript about his father. This positioning of Kahoki's voice in the final section of this thesis reflects the unfortunate state of affairs whereby finding women's voices in the historical records is often much more difficult than finding the voices of men. This does not necessarily mean, however, that women's voices, or more precisely in terms of this project RaukawaToarangatira women's voices, are or have ever been silent. Finding the voices of our tupuna wahine may involve us expanding or shifting our ideas about what constitutes a historical record and where history can be found. It may, as in the case of this thesis, be a matter of "reading between the lines" to reveal taonga which are hidden in plain view in the memories or writing of others.

\section{The order of the chapters}

The order of the chapters of this thesis is inspired by Te Tumu Herenga Waka, the carved meeting house at Te Herenga Waka marae, Victoria University of Wellington. The first marae to be built on a university campus, Te Tumu Herenga Waka was under construction in the early 1980s and opened on December 61986 . The whare is richly decorated with whakairo, tukutuku and kowhaiwhai and represents the aspirations and efforts of a combination of Maori staff and students to see a marae built on the university campus. Two of the prime motivators for the wharenui, Ruka Te Rangiahuta Broughton and Wiremu Parker, died before the wharenui was opened.

In order to comply with strict building codes and health and safety requirements some of the materials used in the building and decoration of the whare were sourced from rather unusual places. Kangaroo leather from Australia took the place of pingao in the tukutuku panels due to its fire retardant properties while the majority of the poupou who stand along the long walls of the rectangular house are 
carved from custom wood, a composite material made from pulped wood, rather than native totara logs. The pou tokomanawa, the pou tahu and the pou tuarongo are carved from totara as are the rest of the poupou which form the tuarongo and roro, the back and front walls of the whare. These parts of the whare form the core structural elements and tell the cosmological stories which connect us to the atua. Similarly to how carvings sourced from custom wood and totara stand alongside each other in Te Tumu Herenga Waka, so too do both the "exotic" and "new" combine with older, Indigenous elements within this thesis to construct the whare whakairo of this work. Both the chapters which explore the published work derived from the writings of our ancestors and the original writings themselves, the "new" and the "older", the "foreign" and "native", have a place and belong in this whare.

The first two sections of this thesis are divided into two chapters. The initial chapters in each of these sections echo the carvings in Te Tumu Herenga Waka made from custom wood and look to newer versions of older texts, the published work which either resulted from or drew on the original writings of our tupuna. The second chapters in each of the first two sections in addition to chapter five follow the example of the carvings in Te Tumu Herenga Waka made from totara and explore the older, original writings of our tupuna.

Chapters one and three are informed by recent developments since the 1990s in the area of the history of print culture. This new historical awareness has come about from a steady broadening in the scope of the historical research (Griffith et.al 1997: 11). Griffith, Harvey and Maslen note, "Printing, in all its phases of production, distribution, and reception influences our lives at every turn from cradle to grave. By means of printing we communicate, express ourselves, and store information (1997: 11). ${ }^{15}$ These chapters are informed by work which recognises the profound influence that books have had and continue to have on Maori lives.

Chapters two, four and five are informed by scholarship which recognises value in the writing of our ancestors. These chapters are influenced by the work of such scholars as Apirana Ngata (most notably his Nga Moteatea series 1928; 1961;

${ }^{15}$ See also Griffith et.al (2000). 
1972; 2006), Bruce Biggs (1960; 1964), Jenifer Curnow (1983; 1985), Margaret Orbell (1968; 1978; 1983; 1991; 2002) Jane McRae (2002; 2004), Anaru Reedy (1993; 1997), Jillian Tipene (2008) and Te Maire Tau (2003, 2011a, 2011b). While this scholarship tends to focus on the attribution, transcription, translation and annotation of early Maori texts, I am concerned with exploring the writing of my Raukawa-Toarangatira tupuna through a literary framework as expressions of tribal identity.

Finally, I'm inspired by the comments of Te Punga Somerville who writes that in addition to being interested in how we might read individual stories, she is interested in the connections between stories (2009: 76). Similarly, I'm interested in the stories that each writer/composer tells, but I am equally interested in the connections between their works. The carvings in the whare whakairo each tell their own individual stories as well as contributing to the work as a whole which is the whare. Further, it is important to note that there are many other poupou who could claim a place in the whare whakairo which is this thesis. It is hoped that others will take up the call to flesh out who these tupuna are, what their stories tell us and more about the nature of their written contributions.

\section{Thesis outline}

Introduction: The introduction to the thesis includes discussion of the title of the thesis as a way of introducing the key theoretical concepts and methodological considerations which underpin this work. My position as the researcher is also articulated. The historical context surrounding the source manuscripts used in this thesis is also foregrounded.

Chapter one: This chapter examines the ways in which subsequent writers have engaged with and used Tamihana Te Rauparaha's biographical manuscript about his father in their own work. This chapter reviews the six major published biographical treatments of Te Rauparaha to 
date written by W. T. L. Travers (1872), John White (1890), T. Lindsay Buick (1911), Peter Butler (1980), Patricia Burns (1980) and Heni Collins (2010) in addition to the English-language translation work undertaken by George Graham between 1915 and 1918. This review demonstrates the different ways in which Tamihana Te Rauparaha's written work has been variously used as a major source text, translated into English and represented in print.

Chapter two: In this chapter, Tamihana Te Rauparaha's manuscript about the life of his father is read as a text which tells us not only about who Te Rauparaha was and what he did but about the writer, Tamihana Te Rauparaha. A literary biography of Tamihana is constructed through paying attention to the ways in which he represents himself within his text about his father as well as what he articulates within his text in regards to the act of writing. This exploration of Tamihana the writer within his text about the life of his father demonstrates Tamihana's literary sophistication and authorial agency.

Chapter three: This chapter examines George Grey's publications Nga Mahi a Nga Tupuna and Polynesian Mythology as foundational texts within the popular genre of Maori mythology. Grey's editing, translating and framing of his source material according to his own colonial ideology is analysed in relation to a manuscript of Maori traditions written by Matene Te Whiwhi.

Chapter four: This chapter explores the forms, functions and meanings of the whakapapa contained in a manuscript written by Matene Te Whiwhi. The poetic and stylistic features of the whakapapa are considered as are their functions as linking devices and narratives in and of themselves. 
Chapter five: Close readings are given of two tangi composed by Rakapa Kahoki. The ways in which Raukawa-Toarangatira identity is made manifest within Kahoki's two tangi are explored with a particular focus on people and place, literally "tangata whenua". In this chapter I argue that references to specific people and places map out a "tribalscape" which centres these two tangi within the realm of RaukawaToarangatira intellectual traditions.

Conclusion: The conclusion of the thesis. Key arguments are reiterated and areas for future research are identified.

\section{Whakawatea}

Tohunga whakairo and scholar Takirirangi Smith writes that the initial stage of building a wharenui is the clearing of the site, a whakawatea through karakia to ensure that obstacles and barriers on the land from former use are ritually removed (2007: 35). The following exploration of the meaning of the title and the relationship between George Grey and Maori manuscripts similarly functions as the whakawatea to this thesis. Through foregrounding the key critical theory which underpins this thesis as well as the historical context of the manuscripts I prepare the site upon which the core chapters of the whare whakairo which is this thesis will be built.

\section{Reclaiming}

Oftentimes, I think we become overly convinced of the efficiency of our use of language. We begin to regard language too casually, thereby taking it for granted, and we forget the sacredness of it. Losing this regard, we become quite careless with how we use and perceive language. We forget that language beyond its mechanics is a spiritual force (Ortiz 2003: 111). 
The seeds of this thesis were sown from a desire to engage with the writing of our ancestors and to spend some time walking with them through the fragrant, colourful garden of their written work. I follow the lead of Abenaki scholar Lisa Brooks who writes that her work on early Native American writers in the Northeast of America is "Most of all...an opportunity to hear their voices, however mediated by the particularities of their place and time, as well as our own" (Brooks 2008: xx). Reading their written work is one way in which we can engage with our ancestors however "mediated" this might be not only by the peculiarities of place and time as Brooks notes, but by the act of writing itself. In reading their written work we are afforded a glimpse, a mere suggestion, into understanding who our ancestors were.

And yet the wonder of touching the same pages which they themselves once held holds a strong albeit slightly surreal fascination for me. Reading their texts I could not help but feel close to the authors who carved their intricate letters of ink upon paper. I hope that I have planted enough evidence of my fascination with these texts throughout this thesis in order that readers take away a sense of what attracts me so strongly to these and other early Maori written texts. It is also my hope that readers of this thesis will themselves come to enjoy, appreciate and respect these literary taonga as much as I do.

While I have taken much joy from reading these and other pieces of our ancestors' writing, I am constantly surprised by how few people are aware of their existence. In a North American context Brooks similarly recalls that when she first began her work on early Native American writing of the northeast, "I was told that looking for writing by Indians would be like looking for needles in a haystack" (2008: xxxv). What Brooks actually found was that there were more writings than could fill her book (2008: xxxv). The same perception might equally be said to exist in Aotearoa in regards to writing by Maori. As Agathe Thornton has noted:

...there is a solid body of Māori literature, both in prose and poetry, but it is known as a whole to very few people: the unpublished manuscripts written by Māori 
collected in three of our largest libraries, Auckland Public Library, the Alexander Turnbull Library, and the Hocken Library (Cited in Garlick 1998: 25).16

One of the aims of this thesis is to draw attention to the wealth of early Maori writing that lies in the public domain. These taonga lie mostly untouched on library shelves and locked in vaults and yet they are readily available and accessible by members of the general public. One very good reason for their relative obscurity is that they are written almost entirely in the Maori language, a language barrier to non-Maori speakers, many of whom are today Maori themselves. Connecting, or, perhaps more properly reconnecting Maori people to the written legacies of our tupuna is central to this project. American Indian literary scholar Craig Womack notes that in the Native American context, "We need...to recover the nineteenthcentury, especially in terms of understanding what Native writers were up to during that time and how their struggles have evolved toward what Indian writers can say in print today, as well as the foundational principles they provide for an indigenous criticism" (1999: 3). Similarly, in a Maori context, we need to recover our early writers and connect their work to ours today. The Maori written tradition is much longer and richer than many of us are aware and it is time that we reclaim our written heritage for the enrichment and betterment of our people.

Indigenous scholars have been calling for more research about Indigenous people to be done by Indigenous peoples, with the concerns of Indigenous people guiding the research methodologies (Smith 1999). This call speaks to the ultimate struggle of many Indigenous peoples for sovereignty, or in the case of literature and scholarship, more precisely as Warrior coined the term, "Intellectual sovereignty" (1995: 122). As Womack asserts in his ground-breaking work Red on Red: Native American Literary Separatism, "Native literature, and Native literary criticism, written by Native authors, is part of sovereignty: Indian people exercising the right to

\footnotetext{
${ }_{16}$ McRae similarly notes that there is little public appreciation of Maori literature, 'Until very recently it was not taught as part of school and university curricula. It is not uncommon to hear or read in letters to the newspaper, opinion of the kind which, it is said, led to the rejection of Apirana Ngata's recommendation in 1925 that the language be a subject for the BA at the University of New Zealand that there is no Māori literature' (1997: 34).
} 
present images of themselves and to discuss those images" (1999: 14). The aforementioned aims of reconnecting with our ancestors through their writing and asserting that Maori do in fact have a literary tradition, come from a place that assumes that it is Maori themselves who best understand the needs and desires of Maori. Accordingly, the acts of reading and writing, or more properly perhaps, of rereading and rewriting can be reframed as sovereign acts. ${ }^{17}$

\section{Early}

As noted in the preface of this thesis, the manuscript texts upon which this thesis is based have been dated as being written between 1849-1852, but rather than use these dates or a broader chronological time marker such as "nineteenth-century", I use the term "early" in the title of this thesis. Using the term "early" highlights the temporal relationship that we have today to the texts explored in this thesis and this underlines our subject positions as writers and readers in our own time. The word "early" reminds us that this writing happened "before us" and marks our own writing as belonging to a much larger and dynamic literary tradition. In his $\mathrm{PhD}$ thesis, Takirirangi Smith expands further on Maori concepts of time and whakapapa korero and notes that, "There is no evidence in whakapapa korero that time was perceived of as an independent abstract notion in the same way as Europeans perceive time. Time was...focused on events and movement around events that occurred in specific locations" (2007: 27). Following Smith, the texts studied in this thesis were written in what can be termed an early period in the history of Maori encounters with alphabetic writing. The "event" around which time is focused on in this thesis is "Maori encountering alphabetic writing".

\footnotetext{
${ }^{17}$ Linda Smith talks about Indigenous peoples approaching every issue with a view to rewriting and rerighting our position in history (1999: 28) while Daniel Justice, a Cherokee literary scholar, describes the process of recovering and recognising the work of early Native writers as "to know again" (2006a. Cited in Brooks 2008: xxvii).
} 


\section{Raukawa - Toarangatira}

This thesis asserts that tribal identities are important to Maori people. As respected leader John Rangihau wrote:

Each tribe has its own history. And it's not a history that can be shared among others. How can I share with the history of Ngati Porou, of Te Arawa, of Waikato? Because I am not of those people. I am a Tuhoe person and all I can share in is Tuhoe history (1992: 190).

Rangihau argues strongly for the recognition of iwi histories and for recognition of his tribal identity. Similarly, although many core themes and ideas and even ancestors are shared between different iwi, each iwi and in some cases each hapu, have their own oral and written literatures. Focusing on tribal literature is at its core, as Charles Te Ahukaramu Royal notes, about who we are and what we know:

Heoi, i whakawhāitingia mai ki ngā waiata a Ngāti Raukawa me Ngāti Toarangatira anahe. Kia whakahaerengia, horo raka, kia puta i raro i te mana o ēnei iwi, hei whakaatuatu i ngā tikanga ā ēnei iwi. Hei te roanga atu, ka kitea iho he rerekē ètehi o ngā wetewetenga kōrero i ā ètehi atu iwi. Ko tā mātou kupu, kei te pai, kei tēnā iwi, kei tēnā iwi tāna kōrero, mā rātou anō rātou e kōrero. E whakaatu ana tēnei pukapuka i ngā mōhiotanga a ō mātou tūpuna. Kāore à mātou whakahē, whakahāwea rānei ki ngā kōrero a te iwi kē, engari, he whakaputa kau tēnei i tō mātou mōhio mō ēnei waiata. Ka waihotia atu tēnei ki runga i te ngākau mahaki, i te ngākau popore ki ngā kōrero a Ngāti Toa me Ngāti Raukawa. Kei reira tōna pūtaketanga (Royal 1994: 14).

This book has been published under the auspices and direction of Ngāti Toa and Ngāti Raukawa; it is a tribal project. Readers will see that some of our traditions differ from those of other tribes. Each tribe maintains its own tradition, and it is not our place to question these. Käti Au I Konei is an exposition of our traditions, of what we know about these waiata and their composers. We do not present this 
information in order to dispute traditions maintained elsewhere, but rather as an expression of what we know and maintain (Royal 1994: 13-14).18

Following the lead of Rangihau and Royal this thesis stresses the value of exploring Maori tribal literatures and furthermore in exploring literatures belonging to tribes to which we ourselves belong. It is important, however, that we also affirm the multiplicity of our identities as tribal peoples, as Indigenous peoples, and more. Pat Hohepa, for example, argued for a more complex understanding of the relationships between iwi, Maori and New Zealand identities:

A person from Waikato...may firstly be Waikato with all that this means in terms of personal identification with the land and river, of allegiance to Te Arikinui Queen Te Atairangikaahu, and in terms of the customs and etiquette derived from their Tainui ancestors. But having allegiance to Waikato does not in any way lessen his or her being Maori. In the same way, being Maori does not lessen his being a New Zealander (1978: 99).

Hohepa complicates the view that one must choose between their tribal identity and their Maori identity and argues that both, and more, can and should be accommodated. Hohepa asserts that individual people can hold a tribal identity, a Maori identity and a New Zealand identity simultaneously. Nepia Mahuika also points out the plurality of perspectives that any one individual may hold:

...beyond Māori and iwi are other intersections such as tāne (male) and wāhine (female), we are members of hapū and whānau, and a host of other identities significant to our own beliefs and positions....We are rich in our diversity, and studies in identity construction have illustrated that identities never exist in isolation, and are always the products of complex intersections, varying binaries, and sophisticated individual and collective perceptions (2010: 27).

A part of the iwi perspective claimed in this thesis is about conducting research as an insider, as a Maori person to whom iwi identity is important. In this thesis I am

\footnotetext{
${ }^{18}$ In an earlier publication Royal goes so far as to assert that there is no such thing as Maori history, only tribal history (1992: 9).
} 
writing about Raukawa-Toarangatira literature as a Raukawa-Toarangatira person. The Raukawa-Toarangatira focus in this thesis affirms my own position as the researcher. In terms of Indigenous research and insider perspectives, prominent Maori scholar Linda Tuhiwai Smith has noted that:

Indigenous research approaches problematize the insider model in different ways because there are multiple ways of both being an insider and an outsider in indigenous contexts. The critical issue with insider research is the constant need for reflexivity. At a general level insider researchers have to have ways of thinking critically about their processes, their relationships and the quality and richness of their data and analysis. So too do outsiders, but the major difference is that insiders have to live with the consequences of their processes on a day-to-day basis for ever more, and so do their families and communities (Smith 1999: 137).

I proceed in this work with the understanding that I have a certain "insider" perspective in regards to this research which holds me accountable to my research and my research community in ways which go far beyond the bounds of other research relationships. As Smith points out above, I have to live with the consequences of my research processes as does my family and community.

Further, my position as an insider has implications for the research. The research has to work harder and not only be intellectually robust and conform to particular western-derived conventions and expectations, but be meaningful to my community and be of some benefit to my people. Being an insider keeps the research honest to the needs of the community and holds me, as the researcher, accountable to more than university processes, structures and more than personal goals and aspirations.

This emphasis on the importance of tribal identities has been applied in literary theory in the context of Native America. Craig Womack, a key proponent of the school of literary nationalism, argues that, "in terms of a Creek national literature, the process has been based on the assumption that it is valuable to look 
toward Creek authors and their works to understand Creek writing" (1999: 4). ${ }^{19}$ Similarly, this thesis assumes that it is valuable to look toward RaukawaToarangatira authors and their works in order to understand Raukawa-Toarangatira writing. This thesis follows the lead of these and other literary theorists from Native America who call for literary nationalism in studies of Indigenous texts (Womack 1999; Weaver et.al 2006; Womack et.al 2008). In arguing for recognition of the specificities of Indigenous nations, the proponents of Native American literary nationalism advance the calls by wider Indigenous research theorists for more research about Indigenous people to be done by Indigenous people, with the concerns of Indigenous people guiding the research methodologies. This call speaks to the ultimate struggle of many Indigenous peoples for sovereignty, or in the case of literature, more precisely as Robert Warrior coined the term, 'Intellectual sovereignty' (1995:122) (abridged from Loader 2008: 30).

\section{Writing}

This thesis explores a whakapapa of alphabetic writing which began when our ancestors first encountered alphabetic reading and writing. Although it is based on alphabetic writing, it is pertinent to take a longer and broader view of Maori literary traditions in order to contextualise writing within a Maori world-view. The late Maori poet and scholar Hirini Melbourne asserted:

...in spite of the treacherousness of the space between the oral and the literary, the rigid distinction between the two can be overstressed. The ancient Maori were surrounded by writing in their daily life: the carvings on posts and houses, the marks on cloaks, the very architecture of the great meeting houses. The fact that texts compositions, speeches, ritual replies, and so forth - were memorized, not written

\footnotetext{
${ }_{19}$ The Creek people are a Native American nation located in the United States of America not to be confused with the Cree people, another Indigenous nation in North America, or with the Cree nation located in Canada.
} 
down, does not mean that the ancient Maori inhabited a world from which writing was absent (1991: 132).

This view of writing which privileges a Maori world-view is echoed around the Indigenous world. In the context of Native America, for example, Bernd Peyer notes, "Highly sophisticated communication networks existed among native societies in the Americas long before the advent of Europeans" (1997: 5). Indigenous peoples the world over have their own ways of communicating across distances and over time and these methods are complicated and enable a full range of messages to be communicated between individuals and groups. Long before Europeans arrived on these shores Maori had their own ways of recording and passing on history, of remembering traditions and intellectualising their world.

In addition to the power of memory, for example, Maori made use of a wealth of mnemonic devices including whakairo (carving), mahi tauira (design and weaving), whai, moko (body tattooing), tohu (physical or metaphysical signs), and tuhi (physical markings) (Haami 2004: 16). In particular, Haami notes that:

Carving - perhaps the most visible mnemonic system in Māori society - has become more prominent over the last century...The carved whare tupuna (ancestral houses) have been likened to 'libraries and learning centres,' 20 with the carvings seen as books of knowledge. Highly symbolic forms and elaborate patterns were carved into wood to memorialise ancestors and the traditions associated with them. The most important aspect of Māori carvings is the messages they hold. Paki Harrison believes that without these messages one would be unable to carve anything. 'Without the korero you have nothing to learn. Without it you have nothing to understand'. Many people think that the basis of carving is the appearance of the finished product, but this is only one consideration. A carving must speak or say something to people ${ }^{21}$ (2004: 16-17).22

\footnotetext{
20 See Jenkins 1991: 8 .

21 Winitana 1994: 14.

22 Te Maire Tau describes purakau as 'a form of oral tradition which also refers to the act of carving a tradition (pu) upon wood (rakau) (2001b: 68).
} 
Maori read and interpreted their world through the forms and structures which were developed by them and passed on knowledge and information orally with the assistance of mnemonic devices such as those listed above. To speak of mnemonic devices is not, however, to equate them with the skills of literacy. The introduction of alphabetic reading and writing to Maori was a paradigm-shifting development which radically altered Maori modes of representation.

A key methodological consideration in thinking about early Maori encounters with the written word is provided by Penny van Toorn in her seminal work Writing Never Arrives Naked (2006). In her work, van Toorn promotes a model of understanding Indigenous literacy which derives from studies carried out by Brian Street, Ruth Finnegan and other anthropologists and ethno-linguists who challenged the idea that there is a single, canonical set of skills and practices that amount to literacy proper (2006: 9). ${ }^{23}$ van Toorn notes:

For those who adhere to the idea that literacy can only be understood within its specific cultural and political contexts, the key question is not How has literacy in itself shaped this or that society? but rather, How and why has this individual, or this group of people, at this particular point in their history, acquired, conceptualised, organised and used their particular reading and writing practices in the manner they have? (2006: 10)

van Toorn argues that literacy is not in itself an autonomous force in human history and furthermore asserts that literate practices are informed by and loaded with their own sets of ideologies which originate in the cultures from which they come. van Toorn's assertion that Writing Never Arrives Naked indeed played out in the islands of Aotearoa New Zealand where reading and writing practices as they were first encountered by Maori came "clothed" in the clerical garb of European missionaries.

\footnotetext{
${ }^{23}$ See Finnegan (1988) and Street (1993).
} 
Maori were first taught reading and writing by missionaries in the early nineteenth-century 24 but were quick to literally spread the word amongst themselves. As Haami notes:

People living in the most isolated parts of New Zealand, far distant from any mission station, soon learned to read. ${ }^{25}$ Missionaries 'found that Men and Women who could say the Catechism and prayers, read and write, that had never seen a missionary, but...had learnt it from one that had been taught'. ${ }^{26}$ Travellers in the interior were often asked to give writing lessons using wooden boards; Māori also used slates and korari leaves. ${ }^{27}$ Pleas to send written material flooded in from all over the country 28 (2004: 19).

Reading and writing were quickly utilised by Maori to meet Maori needs and by the mid-1830s, the desire for books and other reading material among Maori had become 'virtually insatiable' 29 (Haami 2004: 19). An "extraordinary literary outpouring" followed (Orbell 1985: unpaginated) whereby Maori wrote in multiple genres and styles across a plethora of subjects and interests. ${ }^{30}$ Maori wrote letters to each other, to newspapers, to government officials, to Queen Victoria and to missionaries, recorded traditions, religious beliefs, observations, proverbial sayings and songs, produced newspapers and more. Maori wrote about both Maori and non-Maori people, culture, customs, beliefs, recorded observances on the natural world and composed travel narratives (McRae 1997: 32). Maori debated topical issues and wrote on materials which were available to them, on leaves, trees, pou, slate and paper. Thousands of Maori letters, manuscripts, newspapers and other

\footnotetext{
${ }^{24}$ As Haami notes, 'The first attempts to teach the rudiments of literacy to Māori were made in the early nineteenth-century at Parramatta, near Sydney. The students were young men who had joined Pākehā whaling crews. Church Missionary Society missionaries led by the Reverend Samuel Marsden encouraged these Māori to attend the mission school in the hope that they would spread the Christian message to their kin on their return to New Zealand' (2004: 18).

25 Parr (1961: 438).

${ }^{26}$ Markham (1963: 66).

27 Wade (1977: 184).

28 Wright (1959: 175).

29 Parr (1961: 437).

${ }^{30}$ For a comprehensive account of early Maori encounters with and engagement in print culture see McRae (1997) and McRae (1998).
} 
texts dating from this era are preserved in both public and private manuscript collections around the country and the world. ${ }^{31}$ The manuscripts studied in this thesis were produced against the backdrop of this rich literary outpouring.

\section{Otaki}

What identifies a Creek work, in my mind, in addition to its authorship by a Creek person, is the depiction of geographically specific Creek landscape and the language and stories that are born out of that landscape (1999: 20).

Writing from his own tribal centre, Womack draws attention to the importance of the depiction of a specifically Creek landscape within Creek literature. Womack highlights the importance of the landscape to Creek people and how the landscape itself shapes the people who inhabit it. Similarly, I believe that what identifies a Raukawa-Toarangatira work, in addition to its authorship by a RaukawaToarangatira person, is the depiction of a geographically specific RaukawaToarangatira landscape. Naming Otaki in the title of this thesis provides a definable geographic point which links readers to the broad territorial domain of Ngati Raukawa and Ngati Toarangatira. This is particularly important because Ngati Raukawa as a tribal entity is geographically split into two main groups comprising sections who remained close to our Waikato kin (in what is known today as the Waikato area) and sections who migrated to the Ika a Maui-Tau Ihu area in the early nineteenth-century.

Moreover, iwi Maori are linked inextricably to and are defined by their physical territories and landscapes. Indeed, many of our traditions are centrally concerned with how our people came to be here in these islands of Aotearoa. Our waka traditions, for example, tell of us coming from elsewhere to finally settle in

\footnotetext{
${ }^{31}$ As Reedy notes, 'Māori men and women learned to read and write at the same time that they became Christian, in the 1830s and 1840s. From this time on, writers in every iwi produced a voluminous literature: letters, reports, essays, histories, and songs of every kind. Many wrote for immediate practical and political reasons. Others were authorities on the traditions of their iwi who wished to communicate their knowledge and record it for future generations' (1993: 9).
} 
Aotearoa. These traditions explain how we came to be in Aotearoa and validate our presence here and also gesture towards our relationships with each other. Higgins furthermore notes that:

More often than not Māori will use the geographical features to describe themselves as people. This supports, firstly, the whakapapa connection but it also stresses that the whenua is of more significance than the individual person. These descriptions of identity using geographical features are recorded in pepeha (tribal utterances), waiata, and tribal narratives, and are often used as a means of identifying a person; for it is one's ancestors who are more important than the individual (2004: 156).

In a Maori world-view it is not enough to simply claim affinity to one or more iwi, one must also claim affinity to the landscape which nurtures and sustains those people. The anchoring of tribal traditions in a geographically definable landscape is more than simply a way of connecting to the physical landscape. American Indian scholar Vine Deloria Jr proposes the notion of "sacred geography":

Indian tribes combine history and geography so that they have a 'sacred geography', that is to say, every location within their original homeland has a multitude of stories that recount the migrations, revelations, and particularly historical incidents that cumulatively produced the tribe in its current condition...The most notable characteristic of the tribal traditions is the precision and specificity of the traditions when linked to the landscape (2003: 71; 121. Cited in Brooks 2008: xxiii).

Following Deloria, Otaki can be understood as being an important part of a "sacred geography" within the history and traditions of Ngati Raukawa and Ngati Toarangatira. Places are intimately connected with the history of the tribes and the relationships that Maori people form with particular places and spaces are lasting and endure.

There are of course multiple layers and ways of understanding and conceptualising this attachment to ancestral lands. Peoples of Ngati Raukawa, Ngati Toarangatira and Te Ati Awa migrated to these southern lands (southern only in a north island perspective) in the early nineteenth-century in a series of migratory 
expeditions over a number of years therefore leaving our northern homelands to settle in the south-west coast of Te Ika a Maui and the north of Te Waipounamu. These migrations did not occur in one movement and there was some travel between these spaces particularly by those affiliated with the Taranaki tribes. Te Rauparaha's farewell to his Kawhia lands is memorialised in his waiata 'Tera nga tai o Honipaka' (see Royal 1994: 48-51). But while Te Rauparaha's affection for his homelands was strong it was evidently not strong enough to keep him there. We have a sacred geography which is dynamic and ever-changing as pragmatics dictate. The landscape remembers the mobility and movements of people as well as their periods of settlement.

Otaki, for example, has a history which began long before my people arrived there in the early nineteenth-century. The name itself predates our arrival in this area as migrants from our Waikato homelands. As part of take raupatu, land acquisition by conquest, my people took over places which already had names given them by the tangata whenua before us. The sacred geography that Maori have allows for different waves of occupants with different social and political aims, values, affiliations, alliances and priorities and all the specificities that define them. That our people didn't tend to re-name places upon taking them by take raupatu ensures that the land maintains and continues its own sacred geography which is bigger than individual people and bigger even than the tribes.

The continuity of names of land and waterways ensures that a multiplicity of histories are remembered. On Kapiti Island, for example, there are names of certain features whose stories predate the arrival of my people in the area alongside names of other features which are named after Raukawa-Toarangatira ancestors. For example, the highest point on the island is named Tuteremoana, a famous warriorleader of Ngai Tara who distinguished himself in the battles in which Ngai Tara and Rangitane fought against Ngati Kahungunu (McKinnon 1997: Plate 25) while a small waterfall also on Kapiti is called Te Mimi-o-Rakapa and commemorates Rakapa Kahoki's swim from this place to one of the small islands opposite (Carkeek 
2004: 220). ${ }^{32}$ Rakapa Kahoki, whose waiata texts form the basis of chapter five of this thesis, is one of my tupuna, a woman of Raukawa-Toarangatira tribal affiliations whose presence in this area is due to the migrations that our people undertook in the early nineteenth-century. Anchoring this thesis in the place of Otaki, whilst not seeking to supersede or promote my Raukawa-Toarangatira people at the expense of other iwi and hapu, privileges the relationships that my people have with this place.

An essential dimension within a Maori world-view when considering the sacredness of place and space is whakapapa. In theorising about some of the narrative traditions of his Ngai Tahu people, prominent Maori scholar Te Maire Tau notes:

Having secured the land, Tukete's people then went about establishing the 'mental world' for the people to live within and this was done by planting their atua and ancestors upon the landscape...The traditions record that Rākaihautu and his descendants did this by planting his genealogy upon the landscape (2011b: 16-17).

Tau articulates a complex interpretation of Ngai Tahu narrative traditions which entwines whakapapa and whenua in combination with narrative and ceremony to ultimately arrive at "tangata whenua" who are in this case, Waitaha. The relationships that Maori have with their whenua entail much more than mere sentiment or romantic notions of "natural natives". For Maori, the land is bound up with the people, with not only their identities but their histories, stories and very being. The Maori word for land, "whenua", also means "placenta" or "afterbirth". Ka' ai and Higgins note that it is common practice for Maori to bury the whenua, the placenta of new-born babies, in tribal lands thus binding the baby physically and spiritually to their tribal territory (2004: 19).

\footnotetext{
${ }^{32}$ Carkeek additionally notes, 'most maps show this place as the name of the stream there and spell it Te Mimi-o-Rakopa' and furthermore that 'Cowan refers to it as Te Mimi-a-Kahoki' (2004: 220). Interestingly, both of these names use one or the other of Rakapa Kahoki's names.
} 


\section{George Grey and Maori manuscripts}

He pukapuka whaki i nga ritenga o Nga Moteatea me nga Hakirara. Otira, he tini whakamaori i nga hua o roto i nga waiata, i nga haka, i nga whakatauki, i nga karakia, me nga tini raureka i tuhituhia nei ki roto i tenei pukapuka. Tenei kupu, tona ritenga, tona ritenga; tenei kupu tona ahua, tona ahua, o nga kupu i roto i enei tini raweke. $\mathrm{Na}$, e rua, e toru kupu e tino uaua ana ki te whaki, ko te kupu tawhito, ko te reta, ko te kupu o etahi iwi ke, ko nga ingoa (Te Rangikaheke, c.1854).33

This is a commentary on the meanings of the songs in Nga Moteatea me nga Hakirara. Indeed there are very many explanations to be made of the abundant ideas in the songs, chants, sayings, incantations and numerous imaginative arts recorded in the book. Amongst these many poetic contrivances, one word has its various meanings and implications and another its special character and suggestion. And there are some few words which are very difficult to explain - archaic words, those with different spelling, words of other tribes, and names (Te Rangikaheke, c. 1854). ${ }^{34}$

Prolific nineteenth-century writer Wiremu Maihi Te Rangikaheke recorded songs, narratives, whakapapa, karakia, whakatauki and other Maori literary forms in writing, and he furthermore commented on what he had written and what he observed. ${ }^{35}$ These comments are reflective and engaging and make frequently insightful observations which illuminate many facets of his contemporary world and circumstances. As the above example taken from the very first page of his commentary on Sir George Grey's Ko nga Moteatea me nga Hakirara o nga Maori (1853) shows, Te Rangikaheke was also an analytical and critical thinker. McRae and Jacob furthermore note that Te Rangikaheke rather perceptively writes of the same tasks and difficulties that were to occupy Apirana Ngata and Pei Te Hurinui Jones some 70 years later in their own work on Nga Moteatea (2011: 24).

\footnotetext{
${ }^{33}$ GNZMMSS 118, Sir George Grey Special Collections, Auckland City Libraries. Cited in McRae and Jacob (2011: 24).

34 Translation by Hēni Jacob in McRae and Jacob (2011: 24).

35 See Curnow (1983), Curnow (1985), Thornton (1987) and Loader 2008 for more on Te Rangikaheke and his written work.
} 
The history of the Nga Moteatea books begins with such writers as Te Rangikaheke, Piri Kawau, Matene Te Whiwhi and Tamihana Te Rauparaha who wrote waiata texts for George Grey. McRae furthermore notes that in addition to seeking out Maori to write for him that Grey kept his own records of what he heard as he went about the country (1998: 8). Grey's manuscripts contain, "notes on the language and its vocabulary, lists of sayings, tribal histories, popular and legendary stories, songs, chants and incantations, genealogies, accounts of customary practices, and reports of meetings between government and chiefs" (McRae 1998: 8). Regardless of whether these records were physically written by Maori it is important to note that without the assistance of Maori, Grey would never have been able to collect any of the materials that make up the massive written collections of Maori intellectual history and heritage that are housed in archival institutions around the country and the world today. ${ }^{36}$ Maori people were essential to the larger project of the written collection of their intellectual traditions by non-Maori. Both Tamihana Te Rauparaha and Matene Te Whiwhi were collaborators, primary sources, agents and writers in this process of George Grey's Maori collecting activities.

Over the course of his two governorships of New Zealand and other political and personal forays in the country, Grey amassed a huge collection of the primary writings of Maori from all over Aotearoa. Although, as McRae notes, texts from the Te Arawa, Ngati Kahungunu, Waikato, Ngati Toa, Ngati Raukawa, and Te Atiawa tribal areas make up the bulk of the collection (1998: 8). Grey's collecting was not, however, without its own challenges; a fire which destroyed government house in Auckland on 23 June 1848 also destroyed most of what Grey had collected in Australia and the early part of his term in New Zealand (Kerr 2006: 61). The most detailed account of the losses suffered is in a letter written by Grey to his friend Gordon Gairdner of the Colonial Office three weeks after the event:

The collections of many years have been swept away including large collections of drawings illustrative of the aborigines of Australia \& New Zealand wh[ich] can

\footnotetext{
${ }^{36}$ van Meijl notes, 'The development of a bilingual, often literate population of natives was essential for the systematic collection of genealogies and traditions, often in Maori, from "informants"' (1996: 323).
} 
never be replaced. Many of the weapons, utensils \& customs represented in them having now become wholly obsolete. I also lost a large collection of songs \& religious chants, wh[ich] formed portions of the former idolatrous religious service of the old New Zealanders. These were wholly unknown hietherto \& were given to me by old Te Rauperaha [sic] at various times whilst he was under restraint here in the presence of other old chiefs so that I wrote them down under the most careful correction. Such an opportunity of collecting these songs will probably never again present itself, \& I fear that the former mystical worship of the New Zealanders will become one of the forgotten things of the world (Grey 1848. Cited in Kerr 2006: 61).

It is ironic that Grey laments the loss of the material that he had collected from Te Rauparaha whilst he had detained him without just cause. ${ }^{37}$ The "opportunity" of collecting the songs to which Grey refers was not brought about by chance or coincidence but was rather one of the results of Grey's direct actions against Te Rauparaha and his people. The fact that reasonable evidence substantiating Grey's actions in arresting and detaining Te Rauparaha for 18 months without trial has never been found further compounds the sinister undertone of Grey's letter to Gordon Gairdner. ${ }^{38}$ Whereas Grey's focus in his letter is clearly on the loss of such material as he would not have a hope of collecting again, the troubling ethical questions that Grey's methods provoke are ignored. Whilst it appears as though Te Rauparaha co-operated with Grey in his collecting endeavours it is impossible to know under how much duress Te Rauparaha was suffering or under what threats to himself and his people he was acting. ${ }^{39}$ Grey's perceptions in regards to such an opportunity of collecting the songs from Te Rauparaha never again presenting itself

\footnotetext{
37 In 1846 Grey took Te Rauparaha from his Taupo pa at Porirua and then left on the naval vessel Driver (Oliver 1990a: 507). Te Rauparaha was held without charge on another naval vessel, the Calliope, for ten months and then allowed to live in Auckland (Oliver 1990a: 507). Te Rauparaha was finally returned to his people at Otaki in 1848 (Oliver 1990a: 507).

${ }^{38}$ See Burns (1980: 277-283) for details concerning Te Rauparaha's arrest and detainment.

${ }^{39}$ Hilary and John Mitchell note that, 'Te Rauparaha's release had come at an enormous cost. The real price (ransom) of Te Rauparaha's freedom was the sale of the Wairua and Kaparatehau and Ngati Toa's claims to the Kaikoura Coast and more southern districts. The 'negotiations' were conducted without Te Rauparaha's knowledge by younger Ngati Toa chiefs under great duress. His son, Tamihana Te Rauparaha, and his nephews Rawiri Puaha and Matene Te Whiwhi who were called to 'negotiate' with Grey were told that Te Rauparaha would never be released unless they agreed to sell the Wairau' (2004: 351). See also Burns 1980: 284.
} 
was to prove eerily true as Te Rauparaha died in the year following his release on 27 November 1849.

The fire at government house proved to be more of a minor setback in the larger scheme of Grey's collecting efforts in Aotearoa, however, after which he continued with his work with the same zest that appears to have driven him for much if not all of his life. ${ }^{40}$ Grey eventually amassed a collection of Maori manuscript materials which exceeds 9,800 pages, numbers 147 separate works, and is collated into 102 bound volumes (Kerr 2006: 77). As McRae notes, Grey's collection is typical in terms of the type and content of this manuscript legacy, but outstanding in terms of its size and the quality of much of the writing (1998: 7-8). Grey collected a wide range of Maori written work including waiata, whakatauki, historical texts and traditional stories and he enlisted the help of Maori from a range of places around the country to write for him. ${ }^{41}$

Following the fire at government house, Grey continued collecting Maori material and by 1851 he had enough to part-print Ko nga Moteatea, me nga Hakirara o nga Maori. This book was subsequently published two years later in 1853 (O'Leary 2008: 20). This publication was the precursor to Apirana Ngata's Nga Moteatea series and was an important publication in its own right. However, as O'Leary notes, "the fact that it was a Maori-language work inevitably confined its appeal to a small number of scholars and missionaries" (2008: 20). In this, his first Maori publication, Grey drew together a selection of 533 waiata texts from his collection and some narrative pieces which were subsequently printed in 1854 in his Ko nga Mahinga a nga Tupuna Maori (McRae 1998: 13). ${ }^{42}$

Grey equated the waiata with poetry and so associated the waiata with the highest aesthetic forms of literary production in line with the English literary tradition. As Mead notes, "It has long been recognised, even by the earliest students

\footnotetext{
${ }^{40} \mathrm{O}$ 'Leary writes that Grey was 'undaunted' and started collecting again (2008: 20).

${ }^{41} \mathrm{It}$ is notable that Grey also kept a large collection of correspondence written to him by Maori.

42 Williams notes that the second edition of Grey's Nga Moteatea differs from the first only in having a new title-page and preface, and in the addition of sixteen pages to the appendix (1975: xvi). Williams writes, 'The body of the volume seems to have been printed from the same type with a few triffling corrections (1975: xvi).
} 
of the Maori, such as Grey and Colenso, that there as an aesthetic dimension to Maori chant. Grey unhesitatingly classed as poetry the chants which he had in his collection. Colenso did the same" (Mead 1969: 379). Grey himself notes in his preface to his Nga Moteatea that the poetry of "a savage race, whose songs and chaunts [sic], whilst they contain so much that is wild and terrible, yet at the same time present many passages of the most singularly original poetic beauty" (1853: viii).

In addition to appreciating the waiata texts on a literary level Grey also noted their ethnographic value (Kerr 2006: 88-89). Grey writes in his preface:

It was also clear that to those persons who study the history of the human race as developed in the history, customs, and language of different nations, such a work would possess a high degree of interest, and it seemed probably that there would be many persons who would study with pleasure the poetry of a savage race (Grey 1853: viii).

Grey, like many of his Pakeha contemporaries, saw himself as a scholar of Maori who was tasked with memorialising Maori culture and customs in print. This is also made clear in his preface where, after extolling the virtues of the "fertile in labors, rich in love, apostolic in character" missionaries (1853: i), Grey gives his intention in the publication of Nga Moteatea as being the raising of a monument in order "to show in some measure what that country was like before its natives were converted to the Christian faith" (Grey 1853: vii). ${ }^{43}$ Grey's comment reveals that he was concerned with securing some kind of authentic or pure native voice which, in a rather strange perversion from Grey's own Christian perspective, is understood as being otherwise "tainted" by Christianity. The underlying and disturbing implications of this line of thinking rest in Grey's desire as a collector and publisher to memorialise Maori culture and thereby relegate Maori people to existence in a distant and misty past: the implication is that "authentic" Maori people either do not exist or have no place in Grey's contemporary time. Whereas McRae notes that

\footnotetext{
${ }^{43}$ It is ironic that a substantial amount of the primary texts upon which Grey bases his publication were written by Maori who had learnt how to read and write alongside converting to the Christian faith.
} 
"Grey was aware that much could be learnt from the waiata about history, relationships between people, customary etiquette, and current events" (1998: 13), whether or not such "learning" exercises were motivated by altruistic intentions or intentions more sinister is debatable.

It is, however, clear that Grey intended his book as a text for the learned. In a letter to the Reverend Lancelot Threlkeld whom Grey referred to as "a fellow linguist and 'Father of Discovery in reference to the languages of Australia'" (Kerr 2006: 88), Grey writes of his Nga Moteatea that, "It is intended solely for the learned, and I need hardly say that I expect to lose a considerable sum by such a publication, and merely undertake the work for my amusement, and from a desire if possible to render my amusements useful". ${ }^{44}$ Grey outlines his motivation in publishing his Nga Moteatea as a work produced with a specific scholarly audience in mind.

In this and in his subsequent publications of Maori content, Grey made substantial contributions to a growing published literature that was being produced by non-Maori about Maori. That Grey's Nga Moteatea was nearly entirely in the Maori language made little difference due to Maori language being the primary language of communication in Aotearoa New Zealand at the time. In the early to mid nineteenth-century, non-Maori students of Maori culture and customs necessarily had to learn te reo Maori if they were to learn about Maori. It is also important to note that these non-Maori scholars of Maori wanted to learn about Maori in a specific way, as relics rather than contemporaries. The colonial ideologies that justified the shift in power from Maori as the tangata whenua of Aotearoa to non-Maori demanded that Maori be seen as naturally unequal and inferior to Pakeha. In his letter to Threlkeld Grey set out his current project:

You will perhaps be interested to learn that I have now in the press, a work upon the ancient traditional poems of New Zealand. The poems of the natives of this country are extremely fine, and I propose to publish a volume of from three to four hundred pages containing a selection of the finest poems which I have collected in my

${ }^{44}$ Grey (1851). 
journeys through these islands, with a second volume consisting of translations and explanatory notes. 45

Grey once again acknowledges the "extremely fine" examples of Maori poems that he had collected in his journeys throughout the islands of New Zealand. Moreover, this letter is revealing in terms of Grey's interactions with other non-Indigenous peers who were also engaged in collecting examples of Indigenous languages, customs and culture. Grey clearly saw himself and his work as contributing to much larger, global conversations being conducted by non-Indigenous people about Indigenous people. ${ }^{46}$ Grey would ultimately, in fact, come to be regarded as a prominent figure amongst a select group of nineteenth-century collectors and writers who conducted their work specifically on Maori people. Grey's Nga Moteatea is the first of five publications that Grey would go on to publish on Maori language, culture and customs. ${ }^{47}$

What is missing from the discourse of Grey's motivations for publishing Nga Moteatea is the notion that Maori themselves might be interested in such a publication that explores their own culture, customs, language and people. Little thought is given in regards to the potential and desire for Maori to study and learn about ourselves and for Maori to be active participants in the production of a written Maori literature or literatures. This is despite substantial evidence to the contrary

${ }^{45}$ Grey (1851).

${ }^{46}$ As well as procuring manuscripts from Maori whom he had enlisted to assist him in his studies of Maori customs, culture and language, Grey received manuscripts from other Pakeha collectors of Maori material such as the German missionary J. H. F. Wohlers, the Presbyterian missionary James Duncan, and the Reverend Robert Maunsell (Kerr 2006: 78). Grey also owned a copy of the Grammar and Vocabulary of the Language of New Zealand (1820) by Lee and Kendall with Hongi Hika and Waikato, A Grammar of the New Zealand Language (1842) by the Reverend Robert Maunsell, A Dictionary of the New Zealand Language, and a Concise Grammar; to which is added a Selection of Colloquial Sentences (1844) by William Williams, three of the four publications that were available by 1845 that were either in or about te reo Maori and although he did not own the fourth, A Korao no New Zealand (1815) by Thomas Kendall, he possessed a work that contained the word list that was originally compiled by the author of that same publication (Kerr 2006: 75-76). Grey not only upskilled himself in things Maori by collecting material from Maori, he also studied what was available in print.

47 The others being Ko nga Mahinga a nga Tupuna Maori, (1854), Polynesian Mythology and Ancient Traditional History of the New Zealand Race, as Furnished by Their Priests and Chiefs (1855), Ko nga Waiata Maori (1857) and Ko nga Whakapepeha me nga Whakaahuareka a nga Tipuna o Aotearoa (1857). A second edition of Polynesian Mythology and Ancient Traditional History of the New Zealand Race, as Furnished by Their Priests and Chiefs was published in 1885. 
such as that which is found in Te Rangikaheke's manuscripts which show Maori of the time to be active, reflective and critical writers and thinkers. The literature has instead tended to focus on the Pakeha desire to accumulate knowledge about Maori for themselves to learn about, study, categorise and classify Maori.

The waiata contained in Grey's Nga Moteatea vary in type from what Grey refers to as tangi, tau, karakia, waiata wawata, ngeri, whakaaraara, popo tamariki, waiata aroha and more. Some are simply titled such as "He pohane" (1853: 47) while others include more detail in regards to their composer and the reason for the composition as in: "He tangi i titoa e Te Rangikaheke, mo tana tamaiti, mo Te Auhikai, kua mate ki Rotorua" (1853: 49). The amount of context provided accompanying each composition is extremely varied. These footnotes provided by Grey are written in English. The first of these appears on page 9 where, after the text of "Te Tangi a Te Ikaherengutu mo ana Tamariki" Grey notes, "This lament, said to have been originally composed by Te Ika-here-ngutu, was sung by Te Wherowhero, on the death of his brother Kati, or George Grey. It was always sung by the aged chiefs if members of their family die" (1853: 9). Grey interestingly makes reference to the death of the Tainui rangatira Te Wherowhero's brother who appears to have been either named or taken the name of George Grey. ${ }^{48}$ The reference to Te Wherowhero is significant due to his being such a prominent rangatira of his people and exerting a considerable influence on events as they unfolded throughout Aotearoa at the time. The publishing of this waiata also suggests that Grey was either present at Kati's tangihanga or death, or had access to someone who was.

All of the moteatea texts contained in Grey's Nga Moteatea appear in a random fashion with no apparent ordering. The texts are not grouped tribally although some texts by the same composer do appear alongside each other. The hakirara or narratives that are contained in Grey's Nga Moteatea appear in an equally haphazard manner although there are some discernable links and connections. On page 52 for example, "He tangi na Hinemoa, mo tana tane, mo Tutanekai" is followed by

\footnotetext{
${ }^{48}$ As is also illustrated in Grey's letter to Gordon Gairdner discussed above, Grey's own complicity in the collecting and publishing of the waiata that came into his possession tends to be underplayed. Grey frequently had much more of a close relationship to the material that he collected than he let on.
} 
"te kauwhau... o Te Kauhoenga atu o Hine-moa ki Mokoia". The selections of waiata that comprise the bulk of the publication are taken up again halfway through page 57 with a text headed "He Whakawai Taanga Moko". The greater bulk of the narrative sections that are included in Grey's Nga Moteatea are found at the end of the publication as appendices under the title "He Korero Apiti ano no nga Waiata nei". These appendices include the typescripts of three complete manuscripts written by Te Rangikaheke.

Overall, the complete text of 432 pages of predominantly waiata, 110 pages of three narrative manuscripts written by Te Rangikaheke, a 16-page index, and two pages of errata, combine to form a significant piece of published work. Regardless of what we might think of the man and his methods, George Grey's Nga Moteatea in many ways paved the way for more published work and scholarship about Maori to appear. It is an interesting text as much for what it represents as for the times in which it was produced and in terms of exploring just one aspect of Grey's activities during his first term as governor of New Zealand. It is an interesting comment on the relationships that Grey forged with Maori and is a work which suggests complex Maori and Pakeha encounters, interactions, co-operation and relationships. It is interesting to compare the full titles of Grey's Nga Moteatea and Waiata Maori:

Ko nga Moteatea me nga Hakirara a nga Maori

He mea Kohikohi mai na Sir George Grey, K. C. B.; Governor-in-chief of the New Zealand Islands

I tera Kaumatua, i tera Kuia; no Ona Haerenga, e Maha, ki nga Pito Katoa, o Enei Motu.

Ko nga Waiata Maori

He mea Kohikohi mai na Sir George Grey

I tera Kaumatua i tera Kuia no Ona Haerenga e Maha ki nga Pito Katoa o Aotea-roa.

Both titles clearly state that George Grey collected the material contained in each publication and furthermore that Grey collected the material from kaumatua and kuia on his many journeys around the country. The additional nuances that these full titles bring to our understanding of these publications appear to have been 
largely forgotten today due to their commonly being referred to by their shorter titles Nga Moteatea and Nga Waiata Maori respectively. ${ }^{49}$ These additional lines add important, albeit often overlooked, dimensions which contribute exponentially to how these works are both received and understood. It is important to note, for example, that Grey himself acknowledges that he was merely the collector of the moteatea, hakirara and waiata contained within these publications and perhaps even more importantly, that he collected this literature from kaumatua and kuia, Maori elders. This statement acknowledges Maori as the authors of the texts contained within the publications and therefore points to Maori agency within the wider processes used in order to produce these books.

Grey followed his Nga Moteatea with Ko nga Mahinga a nga Tupuna Maori in 1854. Grey subsequently followed this collection of traditional narrative accounts with Polynesian Mythology and Ancient Traditional History of the New Zealand Race, as Furnished by Their Priests and Chiefs, his English-language translation of many of the same narratives that appear in Nga Mahinga (1855). Grey thus produced three publications of Maori material in three years, a phenomenal work rate even for someone as evidently driven and determined as himself. Grey took a break from publishing in 1856 but published two books of Maori material in 1857 entitled Ko nga Whakapepeha me nga Whakaahuareka a nga Tipuna o Aotearoa and a second collection of waiata, Ko nga Waiata Maori. ${ }^{50}$ Whereas Nga Moteatea was published in New Zealand, Nga Whakapepeha was published in Cape Town and Nga Waiata Maori was prepared in Cape Town while Grey was serving a term there as governor of the Cape Colony. ${ }^{51}$

\footnotetext{
49 Similarly, Ngata's work is commonly referred to as Nga Moteatea although the full title is Nga Moteatea: He Maramara Rere no nga Waka Maha (1972).

50 Grey's final publication of Maori material was a second edition of his Polynesian Mythology and Ancient Traditional History of the New Zealand Race, as Furnished by Their Priests and Chiefs in 1885. 51 Williams notes that a second volume of Maori songs collected by George Grey had progressed in 1857 as far as page 56 and that there is a copy of these pages with a pencilled memorandum by Grey that this is the only copy in existence (1975: xv). Williams writes, 'It seems probable that the remainder of the issue was destroyed by fire, and that the work was then abandoned' (1975: xv).
} 


\section{The treatment of Maori-language quotes in this thesis}

It is important to note that Maori language quotes in this thesis are not glossed with English language translations. Discussion surrounding such quotes provides enough context for non-Maori speakers to comprehend the ideas conveyed and to ascertain key points. This approach has been taken in order that the thesis not be subjected to 'labouring under translation' and thus 'weighed down' and so constricted by the space which translation work neccesasrily occupies. Further, the notion that the Maori language not be 'othered' underpins the key methodological bases of this thesis and is grounded in a view which centres 'Maori'. Accordingly, readers who have a good knowledge of both the Maori language and the English language will enjoy a richer and more nuanced reading of this work than those whose expertise is limited to either one of the other of these languages. ${ }^{52}$

\footnotetext{
${ }^{52}$ See pages $11-13$ of the preface for more on the orthographic conventions employed in this thesis.
} 


\section{POU TUATAHI: SECTION ONE}

\section{Chapter One: The invention of history: The history of Tamihana Te Rauparaha’s 'History of Te Rauparaha’}

\section{He korero}

My great-grand aunt, Mairatea Tahiwi, was widowed in 1969 and she remained a widow until her death in 1997. Throughout my childhood we visited this aunt often, my mother perhaps representing the children she had never had and my siblings and I her mokopuna. She had many close friends but few close relatives because her one brother lived in Australia and her own parents had long since passed. Aunty Maira spoiled us often cooking extravagant formal lunches for us, insisting on doing the dishes herself and giving us gifts. One of the taonga that Aunty gifted to my brother was a copy of Peter Butler's Life and Times of Te Rauparaha. Although I was too young at the time to make sense of the text, I liked to flick through the pages looking at the pictures. But what held the most interest for me as a child and for a long time afterwards was the front cover of the book.

Beneath a small, stylised profile image of a sketch of Te Rauparaha and the title of the book is a large, coloured, cartoon drawing of what must have been intended to represent Te Rauparaha. This sketch is also in profile but in contrast to the more refined image at the top of the page, it shows a man with crudely drawn moko designs on his face, untidy facial hair and bulging eyes. His tongue sticks out in a half-committed position of whetero and an indeterminate object in the shape of a knife is struck through his left ear. This cartoon image of Te Rauparaha influenced my ideas about him from very early on in my life. I absorbed the notions that Te Rauparaha was savage, violent, insensible, uncouth and wild and accepted these ideas as regrettable but simple truths in the history of my people.

This caricature of Te Rauparaha had even further consequences for me as a young Maori person. Whether rightly or wrongly, the negative view of Te Rauparaha portrayed in this illustration extended over time in my mind to include Maori culture, history, customs and people. The message that took root in my young mind was that Maori people were, and by association still are, savage, violent, insensible, uncouth and wild. Although this perception was not transmitted in this single isolated illustration, its combined effect with 
other negative images of Maori that appeared on the television, in newspapers and magazines and other media gave me and my siblings an overall negative view of our culture and ultimately of who we were.

In the mid 1970s, respected Ngati Porou scholar Te Kapunga Dewes observed:

Is New Zealand not reaping the harvest of nearly 150 years of cultural violence? What can Maori aspire to if we are not rooted to the land, if there is no language and literary tradition to speak for our souls, if we have not got an ideology (mauri Maori) for our people, if our creative imaginations and leadership energies are weakened by fear of loss of jobs and promotional prospects? Are we not cultural refugees in our own country? (1975: 66).

Dewes stresses the importance of Maori being rooted to the land, of having our own language and literary tradition, our own "ideology" and robust creative imaginations and leadership energies. Peter Butler's Life and Times of Te Rauparaha illustrates the state of being "cultural refugees" that Dewes describes whereby a skewed picture of Maori is presented by non-Maori to Maori and non-Maori alike. Such images are damaging and contribute in subtle but no less real ways to the cultural violence that Maori have been subjected to for some 180 years. Our Aunty Maira, however, could not have predicted that the front cover of Butler's book would play such a negative part in my perceptions of my own identity. She passed on her taonga and knowledge to us as best she knew how. The question that befalls us now is to decide what we will do with the gift of retrospect and our own critical reflection: What books will I pass on to my mokopuna and what effects might they have on their intellectual and spiritual development? What will my legacy to my mokopuna be?

\section{Introduction}

The 'telling of history', whether it be oral or written, is not and never has been neutral. It is always the reflection of the priorities of the narrators and their perceptions of their world (Binney 1987: 28).

Te Rauparaha was a renowned leader of Ngati Toarangatira and Ngati Raukawa whose deeds during the tumultuous period of the early to mid nineteenth-century 
have long since captured the national imagination. ${ }^{53}$ Following his father's death in 1849, Tamihana Te Rauparaha, Te Rauparaha's son, wrote a manuscript biography of his father which subsequent biographic treatments of Te Rauparaha have drawn on heavily and lightly since 1872. The story of the ways in which Tamihana's manuscript about his father has been engaged with and used by subsequent writers and scholars interested in Te Rauparaha does not track in a simple, linear fashion and the wider picture that emerges is complex yet local and is closely connected to the specificities of place. This story bridges a critical leap in which a handwritten manuscript was brought into the realm of print media and published. This conversion from manuscript to print has had lingering consequences in terms of the intellectual history of Raukawa-Toarangatira people not least due to the fact that the print history of Tamihana's manuscript begins in 1872 with W. T. L. Travers and continues through four more Pakeha writers spanning over one hundred years time. The first Maori-authored biography of Te Rauparaha did not appear until 2010.54

This chapter explores the transcription, translation and publication history of Tamihana's biographical manuscript about the life of his father in order to examine the ways in which Tamihana's work has been re-presented to the wider community. Tamihana's text about the life of his father made a significant and in many ways singular contribution to the literature of Ngati Raukawa and Ngati Toarangatira and this contribution is yet to be fully recognised or appreciated. The reclamation of this and other Raukawa-Toarangatira manuscripts firstly by the peoples of Raukawa and Toa, secondly by other Maori, and thirdly by the peoples of Aotearoa New Zealand and the world is imperative to contemporary agendas that seek to restore intellectual sovereignty to indigenous peoples. ${ }^{55}$

\footnotetext{
${ }^{53}$ Ballara interestingly argues that the prominence of Te Rauparaha and Hongi Hika in historical accounts of Aotearoa New Zealand before 1840 is due to the fact that that the events associated with them became commonly known through being published in readily available primary accounts 'by missionaries, explorers and New Zealand Company officials whose success, or lack of it, was affected by these two chiefs' (2003: 33).

54 Heni Collins's Ka Ora Ka Mate! The Spirit of Te Rauparaha (2010) which is discussed further below. 55 The concept of intellectual sovereignty as expounded by American Indian literary scholar Robert Warrior in his work Tribal Secrets: recovering American Indian intellectual traditions (1995).
} 
Maori have their own traditions, histories and stories which form an important part of the broader story of these islands. In her article which reflects on the notions of Maori oral histories and Pakeha written texts, Pakeha historian Judith Binney notes:

There have been two remembered histories of New Zealand since 1840: that of the colonizers, and that of the colonized. Their visions and goals were often different, creating memories which have been patterned by varying hopes and experiences. The Maori oral histories of these events have been largely suppressed histories, although they live on in their own world. In the twentieth century it is the European written histories which have dominated (1987: 16).

This thesis demonstrates that Maori written histories of Aotearoa New Zealand have also been largely suppressed. The translation and publishing history of Tamihana Te Rauparaha's manuscript illustrates some of the ways in which our intellectual traditions have been presented back to us and the wider community and in an example of what Peter Gibbons has called "cultural colonisation". 56 As Linda Tuhiwai Smith points out, "We have often allowed our histories to be told and then become outsiders as we have heard them being retold" (1999: 33). Colonisation as it was wrought upon and experienced by Maori saw to it that many Maori were alienated not only from our lands but from our histories and traditions. This erasure of Maori perspectives and memories from the national consciousness has served the colonial project to the violent and devastating detriment of Maori communities.

The publication and translation history of Tamihana Te Rauparaha's manuscript is concentrated in four time periods. The published works by W. T. L. Travers (1872), John White (1890) and T. Lindsay Buick (1911) which appeared in the first time period sit amongst a larger body of ethnographic work that was being produced about Maori by non-Maori. These works reinforce the general rhetoric at the time that Maori were ultimately destined to die to be replaced

\footnotetext{
${ }^{56}$ Cited in Hilliard, Chris, 1997: ii. See Gibbons (1998), and Gibbons (1986: 32-8). This concept underpins Gibbons' two essays, but for a discussion of the term, see Gibbons (1992).
} 
by superior white races. ${ }^{57}$ Such works aimed to capture the memory of the Maori race before their tragic but preordained fate finally caught up with them. ${ }^{58}$ In contrast, the translation work completed by George Graham in the second time period, from 1917 to 1918, stands out in terms of its singularly impressive integrity and obvious respect for the original text. The twentieth century heralded a new era in the development of a "modern" New Zealand society notwithstanding the disruption caused by World War I. Following a gap of some 60-plus years where no substantial work based on Te Rauparaha's life appeared, two works were published in 1980 by Patricia Burns and Peter Butler. These books could not be more different from each other, and the works that came before them, and signalled the dawning of a new era in scholarship based on Te Rauparaha. The fourth and final time period brings us to Heni Collins's 2010 biography which is situated in our own contemporary time.

All of the writers listed above engaged with Tamihana's manuscript and either produced versions of it or used his manuscript as a primary source in their own work and brought a range of skills to bear on their readings of his text. The resulting transcription, translations and publications are similarly variable and reflect the different concerns of those involved and the different times and contexts within which they were working.

\footnotetext{
${ }^{57}$ See Gibbons (1998) for discussion of the broad shape of New Zealand non-fiction writing at this time.

58 Stafford and Williams note that by 1899 the notion of the dying race expressed, 'the complacent assumption among white New Zealanders that Maori will fade as a living race to be replaced by a mythical version of their past, suitable for romantic art and tourist postcards. It conveys the mournful conviction that the ancient 'type' of the Maori is fading away and needs to be memorialised' (2006: 111). Stafford and Williams furthermore note, 'The dying race concept also reflects what was felt to be demographic observation, which seemed to confirm that the once flourishing race was in fact declining. The task of the pakeha was to 'smooth the pillow of the dying race'. This observation was not supported by demographic fact as recorded in census data, but it had considerable purchase within settler culture.
} 


\section{W. T. L. Travers}

In 1872 W. T. L. (William Thomas Locke) Travers produced the first published account of Te Rauparaha's life. Travers was born in Ireland in 1819 but was mainly brought up in France where his father retired (Shepherd 1990: 547). After serving as a lieutenant in British Auxiliary Legion of Spain in the Spanish Carlist Wars from 1835 to 1838 he studied law in London and was admitted to the Bar about 1844 (Shepherd 1990: 547). He married Jane Oldham at Cork in Ireland in 1843 and the couple had two children, a son and a daughter (Shepherd 1990: 547). The family emigrated to New Zealand and arrived in Nelson in 1849. Travers practised law in Nelson, Christchurch and Wellington and served as resident magistrate in Nelson and also had a fitful political career (Shepherd 1990: 547). But it was Travers's interest in natural history where he left his mark in New Zealand history (Shepherd 1990: 548).

Travers was one of the founders of the Royal Society of New Zealand (founded in 1867 as The New Zealand Institute), a statutory body for the promotion of science which performs the functions of an academy of sciences (McLintock 2009. Electronic source) and drafted the statute under which the institution was established in 1867 (Shepherd 1990: 548). ${ }^{59}$ Travers was also one of its governors until his death, and from 1888 to 1903 was its treasurer, and published some 40 articles on botany, ornithology, geology and ethnology in the Transactions of the New Zealand Institute (Shepherd 1990: 548).

Travers's work on Te Rauparaha was presented orally and in print in at least three different guises. Travers read his series of lectures On the Life and Times of Te Rauparaha before the Wellington Philosophical Society on 21 August, 4 September, and 2, 9, and 30 October 1872 (Travers 1872a). These lectures were first published in

\footnotetext{
59 McLintock notes, 'The Society acts for scientists as a whole, independent of occupational or disciplinary affiliations, in offering the experience and advice of its members to Government on national problems, in representing New Zealand science internationally, and in serving New Zealand scientists in such ways as publication of research, maintenance of a library, and the administration of research grants and memorial awards' (2009. Electronic source).
} 
1872 in Volume 5 of the Transactions of the New Zealand Institute. ${ }^{60}$ Travers's lectures on Te Rauparaha were also published later in 1872, under the title Some Chapters in the Life and Times of Te Rauparaha, Chief of Ngati Toa (1872b). Travers's text was published for a third time in 1906 in a joint publication with the Rev J. W. Stack's text about Te Rauparaha's attack on Kaiapohia under the title The Stirring Times of Te Rauparaha (Chief of the Ngatitoa), also, The Sacking of Kaiapohia. ${ }^{61}$ Travers's work on Te Rauparaha was thus widely disseminated firstly to members of the Wellington Philosophical Society, secondly to subscribers of the Transactions and thirdly to the general reading public.

Written in the vein of a sub-set of early New Zealand non-fiction writing which might be collated under the title "The Maori as he was", 62 Travers begins his account by giving his reasons for writing on Te Rauparaha:

The position occupied by the great chief Te Rauparaha in connection with the establishment and earlier progress of the New Zealand Company's settlements in Cook Straits, would alone justify us in recording all that can still be learnt of the career of this remarkable man; but when, in addition to the interest which his personal history possesses for us in this respect, we find that he took a very important part in the events that occurred in these Islands between the years 1818 and 1840 - leading as they did to an immense destruction of life amongst the then existing population, and to profound changes in the habits and character of the survivors - it becomes important, for the purposes of the future historian of the Colony, that we should preserve the most authentic accounts of his career, as well as of that of the other great chiefs who occupied, during the period in question,

\footnotetext{
60 This publication was renamed the Transactions and Proceedings of the Royal New Zealand Society following the society's name change in 1933 to The Royal Society of New Zealand (http://rsnz.natlib.govt.nz/volume/rsnz_05/rsnz 05 00_000500.html).

${ }^{61}$ Stack's text was first published under the title Kaiapohia: The Story of a Seige in 1893.

${ }^{62}$ In his final paragraph Travers, for example, writes, 'Such is the history of the life and times of a very remarkable man, and of habits and customs which have already become so much things of the past that in the course of another generation there will be scarcely an aboriginal native left who will have the slightest knowledge of them. Indeed, the memory of the events I have related is already becoming indistinct, even to those of the principal actors in these events who are still living'
} (1872: 93). 
positions of power and influence amongst the leading New Zealand tribes (1906: 9-10).

Travers gives two main reasons for writing on Te Rauparaha: Te Rauparaha's association with European settlement via the New Zealand Company and his prominence in significant historic events leading up to the signing of the Treaty of Waitangi. Travers looks to the future and what he imagines will be important "for the future historian of the Colony". Travers was self-consciously in the business of making history and was keen to leave behind something of his own legacy for future generations of New Zealanders. Travers's publication did indeed go on to have wide-reaching implications for all subsequent work on Te Rauparaha and his times. ${ }^{63}$

It is productive to first explore the other sources which Travers makes use of in his work in order to foreground how Travers positioned his own work. In the first two chapters of his book, for example, Travers provides some background information in regards to "the habits and customs of the New Zealanders in especial relation to the ownership of land, and to war" and "their social and individual characteristics" (Travers 1906: 12). Travers is forthright in regards to basing his material for these two chapters on the work of John White and William Colenso, two Pakeha ethnographers who were engaged in writing on Maori at the time, and writes, "I may at once say that in compiling the following notice of these matters I have availed myself largely of White's "Lectures on Maori Customs and Superstitions," and of Colenso's "Essay on the Maori Races" (Travers 1906: 12). Travers positions his own work alongside that of White and Colenso by drawing on their work and so clearly referencing them here. ${ }^{64}$

What is less clear, however, is the form of the source material contributed by Travers's Maori sources. On page 154, for example, Travers introduces a quote from Te Kepa Rangihiwinui, “In the words of Te Kepa Rangihiwinui” (1906: 154) while on

\footnotetext{
${ }^{63}$ Patricia Burns notes that Travers's and John White's work have been considered as basic sources for the life of Te Rauparaha (1980: 12).

${ }^{64}$ Travers carefully notes other non-Maori sources throughout his work such as E. J. Wakefield's Adventures in New Zealand (1906: 158) and Wilson's Three Chapters in the Life of Te Waharoa (1906: 140).
} 
page 155 he introduces a quote from Matene Te Whiwhi, "In the words of Matene Te Whiwhi" (1906: 112). Travers is careful to give the written sources of his nonMaori sources but is more ambiguous in regards to his Maori sources. Travers is similarly vague when he relates a story pertaining to Te Rauparaha's youth:

It is recorded of him, that on one occasion when directed by an old slave of his father's, named Poutini, to fetch water in a calabash, an order which, considering his rank, he would have been quite justified in disregarding, he at once obeyed and fetched it. But, like other youths, he now and then got into scrapes, and, to use the naif language of his son, "he did many good and many foolish actions" (my emphasis) (Travers 1906: 65).

Travers writes that the memorable occasion of Te Rauparaha's obeying one of his father's slaves "is recorded of him" but is unclear on how or where this story is recorded. The episode above mirrors that which appears in Tamihana's manuscript with the exception of the name of the slave in Tamihana's account being Te Whanga (Te Rauparaha 18?: 1-2). Further, Travers delivers some thinly veiled criticism in regards to Tamihana's language skills where he writes, "to use the naif language of his son, "he did many good and many foolish actions"" (1906: 65). Travers here implies that Tamihana's language is that of a low-born or naive person, "naif", and thus belittles Tamihana's language skills and, by association, Tamihana himself. ${ }^{65}$

Although Travers expresses his opinion of Tamihana's writing in these derogatory terms, he goes on to say that he acquired a substantial amount of information in regards to Te Rauparaha from him writing on page 45, for example, that, "On the death of Hape, which will be more specially referred to in the sequel, Te Rauparaha married his chief wife, Akau, who became the mother of Tamihana Te Rauparaha, still living at Otaki, from whom I have obtained a large amount of information respecting the career of his celebrated father" (Travers 1872). Here Travers is overt in regards to Tamihana being a major source of information in

\footnotetext{
${ }^{65}$ According to the Oxford English Dictionary, the word 'naif' means 'A person born in a state of bondage or serfdom' and 'naive' (from the French 'naïf')

(http://www.oed.com/search?searchType=dictionary\&q=naif\&_searchBtn=Search).
} 
regards to Te Rauparaha but is again elusive about the form in which such information was obtained by him.

Travers attributes two large quotes in his text to Tamihana Te Rauparaha, the first totals 394 words concerning the circumstances of the Ngai Tahu chief Tamaiharanui's death (1906: 139) and the second is the single longest quote to appear in Travers's account at just over 1,000 words (1906: 161-166). Travers introduces the first account, "The following is the account given to me by Tamihana Te Rauparaha of the mode in which the unfortunate chief was delivered over to his death" (1906: 139). This account corresponds to that recorded by Tamihana Te Rauparaha on page 58 of his manuscript (Te Rauparaha 18?: 58). The second quote which Travers prefaces, "I think it is as well to give Te Rauparaha's own view of the disastrous affair at the Wairau in 1843, and of its results as related to me by his son" corresponds to the last sixteen pages of Tamihana Te Rauparaha's manuscript (Te Rauparaha 18?: 103-119). Both of these extended quotes which Travers credits to Tamihana Te Rauparaha are in fact paraphrases of Tamihana Te Rauparaha's manuscript.

Later scholars, particularly George Graham who is discussed further below, recognised Travers's reliance on Tamihana's manuscript in his work. Graham, for example, noted that Travers "borrowed largely" from Tamihana's manuscript (cited in Burns 1980: 12). Even earlier than Graham and indeed, intersecting with his own contemporary time, George Grey pasted a note onto the front cover of Tamihana's manuscript which leaves no doubt as to how Grey understood Travers's use of the manuscript. ${ }^{66}$ In his note Grey writes that Travers saw the manuscript and made an English-language summary of it. Travers must have accessed the manuscript through Grey in whose possession it was and who, for all intents and purposes, owned the manuscript. Travers's work simultaneously makes Tamihana's contribution to the literature on the life of his father visible while making the precise nature of that contribution, Tamihana's written contribution, invisible.

66 This note is reproduced in Photograph 1 on page 102 of this thesis. 


\section{John White}

The second writer-compiler to use Tamihana's manuscript was John White in his monumental Government-sponsored, six-volume, bilingual series The Ancient History of the Maori, His Mythology and Traditions (1887-1891). White was born in England in 1826 and, together with his parents, Francis and Jane White and seven siblings, emigrated to New Zealand in 1834 (Reilly 1990: 587). They settled at Mata in Hokianga where Francis established a farm and timber trading enterprise (Reilly 1990: 587). In his early 20s White embarked on a course of self-improvement, revising his lessons and reading widely (Reilly 1990: 587). This work, White claimed, led him to collect Maori song poetry (Reilly 1990: 587).

In the late 1840s White gained the attention of governor George Grey by sending him some manuscripts of Maori traditions (Reilly 1990: 587). When the family moved to Auckland in 1851 White became Grey's secretary and translator (Reilly 1990: 587). White held various offices in government employ over the next fifteen years serving as resident magistrate for the Wanganui region between 1862 and 1865 as well as being appointed a land purchase officer in 1865 (Reilly 1990: 588). In 1872 White worked as an interpreter in the Auckland Native Land Court and the civil commissioner's office (Reilly 1990: 588). Between 1874 and 1878 White edited Te Wananga, a Maori newspaper published by Henare Tomoana (Reilly 1990: 588). This experience and the reputation White had acquired as an ethnographer resulted in his appointment in early 1879 as the compiler and writer of The Ancient History of the Maori (Reilly 1990: 588).

White's Ancient History of the Maori is his largest and best-known work but, as Reilly notes, White's organisational skills were at times inadequate, his methods could be unsophisticated, and the preparation of The Ancient History of the Maori was "typically somewhat disorganised" (1990: 588). In chapter two of the sixth and final volume on Tainui history and traditions, White published "an account of the acts of Te Rauparaha from his birth to the time of his old age" (White 1890: 11). The chapter heading in the English language version reads, "Chapter II. Rauparaha. Ngatitoa: Written by Tamihana Te Rauparaha" and in the Maori language version, "Upoko II. 
Te Rauparaha Ngatitoa: Na Tamihana Te Rauparaha i tuhituhi". While he acknowledges Tamihana as the writer of the account, White made substantial changes to Tamihana's text without acknowledging or noting where and how he had done so. Tamihana's text is thus reproduced by White in a substantially altered form.

One of the most immediately obvious ways in which White alters Tamihana's account is in his addition of one or two waiata at the beginning of every chapter. The connections between the waiata White inserts and the content of the chapter at hand are at best obtuse if not downright tenuous. For example, chapter one covers Te Rauparaha's birth and early life through to the major migratory movements which saw peoples of Ngati Raukawa, Ngati Toarangatira and Te Ati Awa resettle in the southern parts of Te Ika a Maui. However, not only does the waiata that White inserts at the beginning of this chapter not appear in Tamihana's manuscript, there is no obvious relationship between the waiata and the content of the chapter:

E rere ra e te whakarua

Na runga i a Raonga-hiwi ra

Whakarehurehu ai

Ka tuku au kia wheriko

Kia tangi au

E mea nei te tau

Ka taia rawa atu ki tawhiti

Te hokinga mai ki a matou

Ma tou matua koe (e) whakahoki (White 1890: 12).

Depart, O north-west breeze

Across the Raonga range of hills,

That while the evening shade grows less

I may perceive a flash of light,

And weep my sorrow's dirge

To him who says he has

To distance gone from me; 
Nor will he once return

Save when his parent calls him back.

Oh, that I had a love-token of him!

(White 1890: 11).

Immediately following the waiata is a note which does not offer any more clarity on the issue, "He waiata aroha na te wahine ki tana tane i ahua kupukupu kino mai ki aia" (White 1890: 12) which he translates as, "A song of love by a wife who had words of anger spoken to her by her husband" (White 1890: 11). The waiata does little to introduce this first chapter on Te Rauparaha other than to evoke the image of "dusky maidens" and "noble savages". This is in no way a critique of the waiata but is rather a critique of the way in which the waiata is used in combination with the narrative it introduces. The inclusion of this waiata frames Tamihana's narrative in highly romanticised terms which has the effect of removing, or at least distancing, White's reading audience from the events in Tamihana's narrative.

White furthermore adds his own ideas, interpretations and understandings to Tamihana's text despite representing the narrative account as Tamihana's. One particularly glaring example appears on the first page in which Te Rauparaha's family are introduced. In his text Tamihana gives a detailed description of the immediate family group and includes, for example, the names of Te Rauparaha's siblings and the order of their birth. Tamihana also supplies detailed information about Te Rauparaha's parents and in addition to noting that he was the last-born of the family, he writes that Te Rauparaha was also known as Maui Potiki:67

Ko te wahine tenei a Wherawera ko Parekohatu

Ko te whaea tenei o te Rauparaha. Otira tenei

ano o mua ake i a te Rauparaha me ata tuhi

\footnotetext{
${ }^{67}$ Maui is a famous Polynesian ancestor remembered amongst other things for his trickster nature and many superhuman feats. Maui is also remembered by the name Maui-Tikitiki-a-Taranga which commemorates his being thrown into the sea wrapped in the topknot of his father as a still-born child. The name Maui Potiki draws attention to Maui's position in his family as being the last-born, the potiki, of the whanau. Burns writes that Te Rauparaha also being known as Maui Potiki meant that he was lively and mischievous (1980: 12) while Te Rauparaha's position in the whanau as the potiki is a further similarity between him and his famous ancestor Maui. Maui is discussed more in chapter four of this thesis.
} 
o ratou ingoa,

Ko te Rangikatukuatomua

Muri iho ko Whaitohi

Muri iho ko te Kiripaeahi

Muri iho ko Mahurenga

Muri iho ko te Rauparaha, te wakamutu

nga tenei ko tona wakatauki, ko Maui Potiki

(Tamihana Te Rauparaha 18?: 1-2).68

White reframes the way in which Tamihana introduces Te Rauparaha's immediate family:

Tona kainga i whanau ai ko Kawhia, tona matua tane ko Werawera, ko te matua wahine ko Parekowhatu. Ka whanau a te Rauparaha, tokorua ona tuakana, a tokorua ona tuahine. He potiki rawa aia no te whakapakanga. Kahore i whai tikanga nga tuakana, he rangatira anake tona tikanga (1890: 12).

He was born at Kawhia. His father's name was Werawera (heat) and his mother's name was Parekowhatu (plume of stone). He had two elder brothers and two elder sisters. He was the last born of the family. His elder brothers did not show any superior knowledge or power: they were chiefs of rank, and that is all they could assume (1890: 11).

White alters the way in which information about Te Rauparaha's immediately family is presented to conform to his own Euro-centric view by simply giving the names of Te Rauparaha's mother and father, noting that he had two elder brothers and two elder sisters, and that he was the youngest in the family. Layers of complexity and meaning are glossed over by White's heavy-handed editing of the text. Of even greater concern than White's editing work here is his additional comment, "Kahore i whai tikanga nga tuakana, he rangatira anake tona tikanga" (1890: 12) which he translates as, "His elder brothers did not show any superior

\footnotetext{
${ }^{68}$ See pages 11 to 13 of this thesis for comment on the treatment of Maori-language quotes in this thesis.
} 
knowledge or power: they were chiefs of rank, and that is all they could assume" (1890: 11). Nothing even resembling this statement appears in Tamihana's manuscript which suggests that White made this addition himself. ${ }^{69}$ Not only are Te Rauparaha's siblings rendered nameless in White's version, White makes a mental leap in assuming that Te Rauparaha's brothers "did not show any superior knowledge or power" (1890: 11). White furthermore makes no comment at all on Te Rauparaha's sisters one of whom in particular, Waitohi, was a renowned leader of her people. ${ }^{70}$

In another example on the same page White writes about Te Rauparaha, "he tamaiti pai, he ahua tino pai (1890: 12) which he translates as, "He was a goodly child, and of fine appearance" (1890: 11). In his manuscript however, Tamihana writes nothing of the sort pertaining to Te Rauparaha but does include the following in relation to Te Rauparaha's father Werawera, "He tamaiti pai a Wherawera i tona itinga ai he ahua pai hoki ki te titiro atu" (Tamihana Te Rauparaha 18?: 1) and in relation to Te Rauparaha's mother, "Ki ta te korero he kotiro pai a Parekohatu i tona itinga he ahua pai hoki ki te titiro atu" (Tamihana Te Rauparaha 18?: 1). White thus confuses Tamihana's comments made in regards to Te Rauparaha's parents and applies them to Te Rauparaha.

Due to White's version being published, it, like Travers's work, reached and continues to reach a wider reading audience than does Tamihana's original manuscript. Many more examples can be cited throughout White's work. Although he passes the narrative off as a reproduction of Tamihana's manuscript, he made numerous alterations and changes to the text so as to render it a confused version of Tamihana's original text. ${ }^{71}$ While Tamihana's manuscript is available for those who

\footnotetext{
${ }^{69}$ Gibbons notes that White 'rewrote material in his own style ('White Maori' it has been called)' (1998: 59).

${ }^{70}$ Sparks and Oliver notes that, 'Waitohi was a leader in her own right, an influential voice in the deliberations of her people, one whose views were heeded by Te Rauparaha during the troubled times of the southward migration and the resettlement that followed it' (1990b: 571).

${ }^{71}$ Angela Ballara notes that, 'Many 'traditional' accounts were written by Māori in the later nineteenth-century at the request of of such Pākehā students of things Māori as John White, S. Percy Smith, T. W. Gudgeon and others. One of the problems with these accounts is that in the published work Smith, White and the rest were not content just to report them as they were given, but rewrote them, changed them, translated them into English and then back into their own 'correct' form of
} 
wish to seek it out, only a handful of copies in research libraries exist. Travers's and White's published work is far more widely and readily available. ${ }^{72}$ Tamihana's manuscript continues to lie in relative obscurity in the vault and in the bound photocopied version that resides on the Special Collections shelf at Auckland Public Library.

\section{Thomas Lindsay Buick}

Twenty years after White's Ancient History of the Maori was first published, New Zealand-born Thomas Lindsay Buick produced An Old New Zealander, or, Te Rauparaha, the Napoleon of the South (1911). Buick, the son of English immigrants John Buick and his wife Margaret, was born in 1865 in Oamaru (Traue 2010. Electronic source). Buick was educated at state schools in Oamaru and moved to Blenheim around 1884 to practice his trade as a carpenter (Traue 2010. Electronic source). He became involved in politics and was appointed a Liberal whip in 1893 but his independence of mind soon led to disagreements within the party (Traue 2010. Electronic source). In 1897 Buick had moved to Palmerston North and had purchased an interest in the Manawatu Standard (Traue 2010. Electronic source). In 1913 Buick joined the United Press Association in Wellington as a parliamentary reporter (Traue 2010. Electronic source). He became first assistant in 1917, and was senior parliamentary reporter from 1918 until his retirement in 1933 (Traue 2010. Electronic source). He was chairman of the press gallery in 1928 and a president of the Wellington Journalists' Union (Traue 2010. Electronic source).

During his career as a journalist Buick wrote twelve books and a small number of pamphlets, many of which he published at his own expense (Traue 2010.

\footnotetext{
Māori...European scholars performed a scissors-and-paste job on Māori accounts, selecting sections, patching them together to create a plausible sequence, and rejecting others that did not agree with their own pet theories. Sometimes they plagarised Māori authors without acknowledgement, and at others they plagarised each other' (2003: 38).

72 This trend continues today where Travers's Some Chapters in the Life and Times of Te Rauparaha and White's entire Ancient History of the Maori series have been digitised and are available via the internet but Tamihana's manuscript has not been digitised.
} 
Electronic source). ${ }^{73}$ Buick's first book, Old Marlborough, was published in 1900 and his second book, Old Manawatu, followed in 1903 (Traue 2010. Electronic source). After completing An Old New Zealander Buick went on to publish his best-known book, The Treaty of Waitangi, in 1914 (Traue 2010. Electronic source). Of Buick's published work, Traue notes that as well as having had "a fluent prose style and firm sense of narrative structure" Buick "synthesised a wide range of printed sources and, particularly for his earlier works, sought out eyewitnesses and others closely associated with historical events" (2010. Electronic source).

Buick alludes to this "synthesis" of a range of printed sources in the acknowledgements section of An Old New Zealander where he expresses his thanks to the authors "of the many existing publications on New Zealand" (1911: viii). Gibbons takes this notion of Buick's synthesisation of printed sources a step further claiming that "Buick deliberately added imaginative colour to the documentary framework" (1998: 66). Gibbons furthermore asserts that, "Though Buick was prepared to challenge popular misconceptions...his own interest was in myth-making, and his histories were attempts to depict a glamorous and dramatic past" (1998: 66).

In her book Te Rauparaha: A New Perspective explored later in this chapter, Patricia Burns is highly critical of Buick's work and identifies a number of specific instances where Buick expresses his own views and opinions within his text. Burns notes, for example that, “T. L. Buick...took Mundy's report that he "covered his old grey head with his mat, and remained for hours immovable" and converted it to a preposterous "covered his old grey head with his mat, and for two hours sat and sobbed like a child" (Buick 1911: 321)" (Burns 1980: xix). Burns demonstrates how Buick twists Mundy's words to produce an account which belittles Maori people, culture and customs.

Buick locates his work within the wider genre of ethnographic writing about Maori that was being produced at the time and clearly saw his work as making an

\footnotetext{
73 See Hilliard (1997: 52-78 ) for a a fascinating description of the written work that Buick and his contemporaries produced in the inter-war period.
} 
important contribution to this emerging body of work. Further, in his acknowledgements section Buick thanks S. Percy Smith, for the "kindly interest" he displayed in the progress of his work (1911: viii) and dedicates his book to Smith (1911: v). Smith was, not unlike Buick, "an exemplary model of a self-educated amateur who had risen to the heights of intellectual endeavour" (Byrnes 2010. Electronic source). Buick's acknowledgement of Smith is notable because in doing so, Buick makes reference to one of the popular scholars of Maori people and culture at the time. In addition to fulfilling his official duties as a surveyor and public servant, Smith collected and recorded information about Maori history and culture, co-founded the Polynesian Society in 1892 with Edward Tregear and was co-editor of The Journal of the Polynesian Society and its chief contributor until his death in 1922 (Byrnes 2010. Electronic source). ${ }^{74}$ During his 30-year association with the Polynesian Society he published a large number of articles, books, monographs and pamphlets on Polynesian history, mythology, customs and tribal lore (Byrnes 2010. Electronic source).

\section{George Graham}

Events in the second key period of activity surrounding Tamihana's manuscript took a different turn when George Graham took up the task of translating Tamihana's manuscript into English between 1915 and 1918. Graham was a New Zealand-born Pakeha whose family background and relationships gave him a lifelong interest in Maori history, language, culture and artefacts (Graham and Curnow 2010. Electronic source). Graham drew on the knowledge of Maori informants, mostly from Hauraki and Auckland, to compile a large number of Maori language manuscripts which he

\footnotetext{
${ }^{74}$ Gibbons gives a scathing assessment of the Polynesian Society, 'A small number of Maori people were members, but the Society was essentially a cloak of scholarly respectability under which the functionaries of imperialism, old soldiers, surveyors, and clergy, could indulge their fascination about 'primitive' people. The Society both sanctioned and encouraged the objectivization of the Other; even when the Society was not directly involved in the process of compilation and publication, it indirectly authorized a large body of literature. Most of this literature was undistinguished as writing but important for the particular topoi and genres which it established' (1998: 59).
} 
then translated into English (Graham and Curnow 2010. Electronic source). He was a member of the Polynesian Society from 1902 and contributed a number of articles to its journal (Graham and Curnow 2010. Electronic source).

The Auckland Public Library arranged for a typescript to be made of Tamihana's manuscript and forwarded the pages as they were completed to Graham for translation. Collins, however, notes that the typist misjudged spelling in places and even omitted some sections of the text (2010: 9). In a letter written in December 1923, Apirana Ngata advised the Chief Librarian, Mr Barr, that the typescript "will require very careful editing before it can be passed as correct for publication" (1923). This double-handling in which Graham composed his English translation from a typescript made by an unknown typist may explain, at least in part, why Graham's translation is "uneven" (Burns 1980: 12).

In a series of letters to the Chief Librarian of Auckland Public Library, Graham refers to Tamihana's manuscript variously as “Tamihana Rauparaha's History" (1914a), “Tamihana Rauparaha's Manuscript” (1914b), “Rauparaha's History" (1915), and finally as "Life and Times of Te Rauparaha" (1918). These different ways in which Graham refers to Tamihana's manuscript firstly as an historical text, secondly as a manuscript, thirdly as a history of Te Rauparaha, and finally as a biographical-historical text centred on Te Rauparaha suggest some of the different ways in which Tamihana's manuscript can be conceptualised.

Graham's work is particularly interesting for the recognition he accorded Tamihana's manuscript. Whereas Travers, White and Buick had variously mined Tamihana's manuscript for information, and, in the case of White made his own alterations and changes to the text before publishing it, Graham set about completing a translation of Tamihana's text and furthermore aimed to complete more work which would add to the scholarly value of Tamihana's written work rather than detract from it.

Not content to leave his work with Tamihana's manuscript at an English translation, itself no small undertaking even allowing for the later criticisms Graham's translation work received, Graham proposed to compile an appendix 
explaining the Maori incidents not clearly set forth in the manuscript, a glossary of dates and names of places and people mentioned in the manuscript, and a general index (Graham 1918). Unfortunately Graham's plans for further work on Tamihana's manuscript never came to fruition. Although plans for Graham's translation to be made available in print were at the time afoot, these were not to be realised for another 60 or so years due to the unfavourable supply and cost of paper as a result of World War I (Bass 1918). Graham planned more work on Tamihana's manuscript, demonstrating that he recognised the significance of Tamihana's manuscript and its intellectual value.

Following Graham's burst of scholarly activity around Tamihana's manuscript, the manuscript lay all but forgotten for the following 60 or so years. The publishing and other intellectual and scholarly work that Travers and White, Buick, and Graham work fed in to other scholarship and wider conversations on Maori that were current at the time. The wide-reaching effects of their collective published work on Te Rauparaha was to form the basis, at least for non-Maori, of knowledge, information and narratives on Te Rauparaha from as early as 1872 through to 1980, a period of over 100 years covering a large chunk of the post European-contact era of the history of these islands.

\section{Patricia Burns}

Following the turmoil of the 1960s and 70s in terms of New Zealand race relations, land rights, human rights and Maori intellectual activities, the 1980s were ripe for new, revisionist histories. In 1980 Patricia Burns, a Pakeha freelance writer and researcher who gained her PhD on the history of the New Zealand Press from Victoria University in 1957,75 published her award-winning biographic treatment of Te Rauparaha, Te Rauparaha; A New Perspective. ${ }^{76}$ The title of Burns's book focuses attention on the "new" aspect of her work and signals a movement towards

\footnotetext{
75 'The Foundations of the New Zealand Press'. Unpublished PhD Thesis. Wellington: Victoria University College.

${ }^{76}$ Burn's work won the Goodman Fielder Wattie Book award in 1981.
} 
alternative ways of thinking and theorising about Te Rauparaha and broader New Zealand history. Burns's biography draws on a wide range of unpublished sources including unpublished manuscripts, private papers, letters, published government papers, official papers and New Zealand Company records as well as a selection of published material including journal articles, newspaper articles and books. Burns's work is constructed critically and carefully and this results in the most in-depth and thorough study of Te Rauparaha to be produced thus far. Burn's study remains important today over 30 years after it was first produced.

In addition to the comprehensive research effort that Burns's book represents, it is also noteworthy that some translations from Maori material into English were made by Bill Parker a respected and revered adult educationalist, broadcaster, university lecturer, community leader, and kaumatua (Walker 2010. Electronic source). Walker notes that Parker's counsel as a Maori language expert was "wise and trusted" and that from the mid 1960s he was consulted by many of the country's writers on Maori studies and Maori history (2010. Electronic source). Parker wrote for Te Ao Hou and other publications on proverbs, waiata and his other areas of interest and was regarded as one of the foremost translators of Maori. He was an editorial consultant and translator to numerous projects, a member of the committee that revised H. W. Williams's Dictionary of the Maori language and of the Advisory Committee on the Teaching of the Maori Language (Walker 2010. Electronic source). In 1985-86 he acted as a Maori adviser to The Dictionary of New Zealand Biography project and was influential in commending the project to Maori groups and in assuring them that the language would be treated with respect (Walker 2010. Electronic source). Burns furthermore opens her acknowledgements section with the following:

Most grateful thanks are expressed to the following Maoris, whose kindness and help have made this book possible: Mr Bill Parker, Maori Studies Dept., Victoria University, Wellington. 
Of Ngati Toa: Mr and Mrs A. R. Wineera, Mr P. Rei, Mrs P, Tarawhiti, Mr and Mrs Matu Solomon, Mr August Wineera, Mrs C. Metekingi, Mrs E. Spragg, Mr Kohe Webster.

Of Ngati Raukawa: Mr Matenga Baker, Mr M. R. Winiata, Mrs P. Shaw, Mr M. R. Love (Te Ati Awa), the late Mr M. R. Jones (Waikato), Mr S. O'Regan (Ngai Tahu), Mr R. Turnbull (Ngati Hikairo); Professor S. M. Mead, Maori Studies Dept., Victoria University; Dr Ranginui Walker, Auckland University; Mr J. P. Malcolm, Wellington Teachers' College (1980: xii).

Burns thus acknowledges the assistance of a veritable constellation of Maori scholars, intellectuals, kuia and kaumatua who helped in the production of her book. While it is definitely pleasing to see contemporary Maori being acknowledged in such a specific and prominent way, it is important to note that besides mentioning Bill Parker's translation work there are no specific in-text references to indicate the specific contributions that these people made to the book. ${ }^{77}$ Moreover, Burns has little to say about Tamihana's writing. The few brief comments that Burns does give about Tamihana's manuscript appear on the first paragraph of chapter two:

Tamihana Te Rauparaha's History of his father, with a translation made by George Graham in 1915-18, is part of the Grey Collection in the Auckland Public Library. The History was used by the two Victorian scholars, W. T. L. Travers and John White, whose works have been considered as basic sources for the life of Te Rauparaha Travers's series of lectures in 1872 to the Wellington Philosophical Society, subsequently published as The Stirring Times of Te Rauparaha [1] and White's Ancient History of the Maori (Vol. 6, published 1890).* George Graham wrote, however, that while Travers and White "borrowed largely" from Tamihana's History, it had not been translated, and that "only parts" had been paraphrased. [2] Graham's own translation is uneven, and has not been published (1980: 12).

While Burns's comments do shed some light on the translation and publication history of Tamihana's manuscript, they do not offer any thoughts on Tamihana's

77 Burns notes in her abbreviations that unless otherwise stated, references are to GNZMMSS 27b, George Graham's English language translation (1980: xi). 
significant written contribution in regards to Te Rauparaha. Yet despite this, Burns quotes from Tamihana's manuscript throughout her book and notes where Tamihana's version of events either agrees with or departs from other published and unpublished sources. On page 190, for example, Burns describes a chase on the sea where some of the men of the overloaded canoe containing Te Rauparaha and his family were frantically baling, jumping in and out of the canoe, sometimes being thrown out by Te Rauparaha, until they could board the canoe of Rawiri Puaha. Burns writes in a footnote:

According to Tamihana, who had been in the canoe. A Ngati Hau told John White (Ancient History, Vol. 6, p. 103) that women, children and aged men were thrown overboard by Te Rauparaha to enable him to escape. This was seized on by later writers, including Buick (An Old New Zealander, p. 192), but is not likely to be true. It is not mentioned by Stack and other early sources; Travers did not believe it so and Tamihana's story offers sufficient explanation.

Burns takes a considered approach to the conflicting versions of the episode as given by Tamihana and an unnamed Ngati Hau source, and compares these against the Rev. J. W. Stack and other unnamed "early sources". Burns also notes that Travers did not believe White's version to be true. While Burns's work is notable for her referencing of Tamihana's manuscript throughout her work it is unfortunate that she only includes quotes in English language translation and does not indicate where or whom these translations are from.

\section{Peter Butler}

In the same year that Burns's book was published, Peter Butler produced an illustrated English translation of Tamihana's manuscript. 78 No biographic information is available about Butler although by his own account in his short introduction to his publication he was a keen amateur historian. This book appears

\footnotetext{
78 The impact that this book had on me in my childhood is outlined in the opening narrative of this chapter.
} 
to be his only published work. Although he does not supply the source of his translation, it is clear that Butler reproduced Graham's translation work albeit in an extensively edited form. Worse still than not acknowledging his use of Graham's translation work, Butler makes no mention whatsoever of the fact that his publication is a translation of a text that was originally written in Maori. Butler disregards a raft of issues associated with translation in particular the relationship between language, culture and world-view and assumes that a translation of Tamihana's manuscript is as good as, or the same as, Tamihana's original work.

Despite writing in the final paragraph of his introduction that he believes that, "the primary sources of history should be made available for the public to read through their variously coloured spectacles, rather than having a predigested version dished up by someone called an historian" (Butler 1980: 7), Butler writes, "[Tamihana] was certainly no scholar and the manuscript had to be extensively edited, but I have not cut anything of substance or interest" (Butler 1980: 7). Butler clearly believed that through his book he was making a primary source text, Tamihana's manuscript, available for the public to read and make up their own minds about. In his brief introduction Butler notes that Tamihana attended a mission school and learned to write, and was dedicated to recording the details of his father's life, but does not mention that Tamihana's writing is in Maori rather than English. Butler thus does not allow for issues around translation or even his own editing of the text. Butler equates Graham's English translation with Tamihana's manuscript and criticises what he perceives to be Tamihana's poor standard of writing. In short, Butler's work smacks of a superiority complex which is incapable of acknowledging its own inherent subjectivity.

Butler's narrative reads as confusingly as does his introduction. Notwithstanding the "extensive editing" that Butler undertook, the prose does not scan well and reads faultingly. As the first publication in the history of the major publications to be produced on Te Rauparaha to reputedly bring Tamihana's manuscript to print, it is disappointing to say the least. Butler's editing work here echoes that of George Grey who, over one hundred years prior, embarked on his 
own editing and publishing of Maori manuscripts. ${ }^{79}$ Grey's editing out of what he similarly assumed to be of no "substance" or "interest" resulted in the original manuscript texts being distorted and presented in ways which fit with his own personal agenda.

Butler's publication presents a remarkable challenge when read alongside Burn's book: that two works about Te Rauparaha published in the same year are so extremely different from each other could be read as a sign of the changing times. Whereas Burns's work signals change in the ways that Maori historical-biography might be undertaken, Butler's work, on the other hand, reminds us that the Pakeha-centric tendrils of the old guard of non-Maori writers and scholars of Maori are reluctant to lose or even loosen their grip on this particular intellectual territory. This is not to say that Burn's work is a perfect example of scholarship on Maori, but it does take some significant steps towards more complex and ethically sound work. When viewed alongside each other, Burn's and Butler's work can be respectively seen to represent a step forward towards research which might be useful to Maori communities, and a step sideways and perhaps even backward towards work which is of limited use to Maori people and Maori communities.

\section{Heni Collins}

Thirty years after Burns's and Butler's work appeared, Heni Collins published her biography of Te Rauparaha, Ka Mate, Ka Ora! The Spirit of Te Rauparaha (2010). This is the first book-length biographic treatment of Te Rauparaha by a Maori author. Collins furthermore claims a kinship relationship to Te Rauparaha through being a descendant of Te Rauparaha's uncle, Hapekituarangi and asserts her identity as a Ngati Raukawa woman belonging to the Ngati Kikopiri hapu. Collins's work was launched at Takapuwahia marae where it was blessed by Matiu Rei, the chief executive of Te Runanga o Ngati Toa Rangatira, and Te Waari Carkeek, the tumuaki,

\footnotetext{
${ }^{79}$ See Loader (2008: 35-57) and chapter three of this thesis for more on Grey's editing of early Maori manuscripts and Biggs (1952) for a comprehensive assessment of Grey's editing of Te Rangikaheke's manuscripts.
} 
or chairperson of Te Runanga o Ngati Raukawa. ${ }^{80}$ Collins, a former newspaper journalist, describes the book as "an updated version of [a book by Patricia Burns]" which aims to "provide more cultural authenticity by returning to early manuscripts in te reo, a stronger understanding of our rights as Maori by having looked at Waitangi Tribunal reports, but also attempts to offer the perspectives of other iwi and Europeans." 81

In the acknowledgements section at the beginning of her book, Collins acknowledges Tamihana Te Rauparaha's manuscript as one of the most important sources for her book and writes, “The manuscript of Te Rauparaha's son Tamihana...has been studied carefully - both in the original handwritten reo version (ATL MSY 2073), and the versions typewritten in te reo (MS 220), and in English (MS 221)" (Collins 2010: 8). Collins makes a point of mentioning that she studied Tamihana's original manuscript as well as Graham's translation and the typescript that Graham made his translation from. Collins includes thirteen quotes from Tamihana's manuscript in her work which are given in Maori with an English language translation and fifteen quotes from Tamihana's manuscript which are given only in English. ${ }^{82}$ Given these relatively low numbers of in-text citations of Tamihana's manuscript in her work it is negligible whether Tamihana's manuscript has any significant impact in her overall work.

Collins furthermore brings her own editing skills to bear on Tamihana's written work. Collins outlines what these alterations are in a note on sources and te reo at the beginning of her book:

Quotes from Tamihana Te Rauparaha's text about his father's life have been adjusted for ease of reading. Tamihana had a number of unusual spelling habits - for example

\footnotetext{
80 (http:/ / www.stuff.co.nz/dominion-post/news/local-papers/kapi-mananews / 4320993/Descendant-of-Te-Rauparaha-traces-the-history-of-Poriruas-haka).

81 (http:// www.stuff.co.nz/dominion-post/news/local-papers/kapi-mananews /4320993/Descendant-of-Te-Rauparaha-traces-the-history-of-Poriruas-haka).

82 It is unclear whether Collins uses Parker's translations (via Burn's book), Graham's translations or her own as she does not provide references for the English language translations. Collins writes in a section at the beginning of her book headed 'A note on sources and te reo' that, 'The 1928 George Graham translation (GNZMMSS 27b) has been used only as a guide, with primary reference being made to the original' (2010: 9).
} 
his use of the letter $h$. He consistently wrote 'Wherawera', who is commonly known as Werawera, and instead of 'whakatauki' he would write 'wakatauki'...Dropping the $\mathrm{h}$ [sic] is consistent with a dialectal habit in some parts of the North Island, but adding an $h$ is rare (Collins 2010: 9). .83

Collins highlights a particularly striking feature of Tamihana's writing in this manuscript noting his unusual addition of the letter ' $\mathrm{h}$ ' in many names and words where it does not commonly appear in modern Maori. While this feature of Tamihana's writing is certainly noteworthy, particularly in light of the recent decades of te reo Maori revitalisation efforts and Maori language debates, it is a matter of some regret that Collins felt the need to "adjust" Tamihana's writing to fit within a particular contemporary framework. Tamihana's use of the letter ' $\mathrm{h}$ ' is internally consistent and I suggest that readers of Maori would have no trouble in comprehending Tamihana's text the way that he himself wrote it. Something of the individuality of the text and the writer is lost when stylistic features such as this are ironed out in the name of contemporary standardisation practices and neither is it clear that standardising the text thus adds anything of significance to the text. The orthographic practices adopted by Collins in her book furthermore privilege "standard" over "iwi" writing conventions which results in the specificities of language at a tribal level being lost. This poses a serious blow to those of us who work with early Maori written texts with a view to considering our systems of writing to the iwi level. There are also important historical and linguistic issues to consider not least of which are pronunciation and dialectal or regional differences in pronunciation. This issue is all the more ironic as this book was produced by an iwi member. In her BA Honours Dissertation which explores the intersections between oral history and Maori biography, Rewa Morgan crucially notes:

The latest biographical publication of Te Rauparaha from a tribal member, Collins narrative is beautifully and thoughtfully illustrated with prints, photographs and whakapapa. However, Collins history lacked any intimacy that one might expect from whanaungatanga (kinship ties) (2010: 13).

83 This feature of Tamihana Te Rauparaha's writing is also mentioned in the preface of this thesis. 
Morgan highlights the fact that although Collins's work is written by a tribal member there is little in the work itself which defines it as a tribal work. Collins's work is essentially an updated, beautifully illustrated reproduction of Patricia Burns's work of 30 years earlier.

\section{Conclusion}

The various ways in which biographers of Te Rauparaha have represented Tamihana Te Rauparaha's writing about the life of his father have undermined and distorted Tamihana's valuable written contribution. The texts on Te Rauparaha produced by each of the writers profiled in this chapter often tell us in more about the writer and their historical context than Te Rauparaha.

While all the published works which have dealt with Te Rauparaha have variously borrowed from, drawn on and in the case of Butler reproduced Tamihana's written work about the life of his father, Tamihana's manuscript has in many ways remained hidden in plain view beneath the editorial decisions of subsequent writers. This mirrors the way in which Tamihana's manuscript remains hidden in plain view at the Auckland Public Library whereby anyone can in theory access it but to access it one has to know firstly of its existence and secondly how to navigate the conventions of the library. Although Tamihana's text has been and continues to be widely consulted and is therefore highly visible, it remains in other ways invisible.

Tamihana Te Rauparaha's manuscript about the life, history and times of his father is yet to be published complete and in a way that maintains the integrity of the text and adequately contextualises the original writer. ${ }^{84}$

\footnotetext{
${ }^{84}$ Reedy provides some good examples of how this might be achieved in his works Ngā Körero a Mohi Ruatapu Tohunga Rongonui o Ngāti Porou: the writings of Mohi Ruatapu (1993) and Ngā Kōrero a Pita Kāpiti: the teachings of Pita Kāpiti (1997). Haami (2004) has some good ideas, and Garlick (1998) raises many important issues to consider when attempting such work.
} 


\section{Chapter Two: Reading Tamihana Te Rauparaha}

\section{He korero}

I grew up in Wellington. Our relatively close proximity to Otaki meant that my siblings and I were regularly taken back to our marae, Raukawa, in Otaki. I remember attending tangihanga, 21 ${ }^{\text {st }}$ birthdays, and an assortment of other hui. I also remember the way the marae looked to me back then: the rows upon rows of cabbages in the garden out the back and the big, weeping tree that all the kids liked to climb. Less than five minutes walk down the road past Raukawa, Matene and Hadfield streets stands our church Rangiatea. In my child's mind the white weatherboard structure looked small but regal against the crisp green lawn and trees, but once inside, the whitewashed exterior gave way to an expanse of warm brown wood in kokowai tones, tukutuku, whakairo, and mesmerising, endlessly curling kowhaiwhai. The inside of the church sheltered all from the normal comings and goings of everyday life as we celebrated and grieved together.

Opposite the front gates of the church stand two memorials surrounded by a low, concrete and iron fence. To the left stands the concrete monument erected in 1927 which replaced the original wooden Jubilee Pole erected in 1880 to commemorate 40 years of the Christian mission on the Kapiti Coast. To the right, atop a high, concrete plinth sits a bust of Te Rauparaha which was commissioned in Sydney by his son Tamihana. Although he was a prominent figure in the construction of Rangiatea, Te Rauparaha did not live to see it completed. He died in 1849, and was buried in the church grounds on the slope of Mutikotiko Hill.

The relationship between Rangiatea and Te Rauparaha is reflected in the physical positioning of the memorial of Te Rauparaha in relation to the church, the two facing each other from opposite sides of Te Rauparaha street. The role that Te Rauparaha's son Tamihana played in the establishment of the church, the township of Otaki as well as the memorial to Te Rauparaha, however, has paled in the shade of the long shadow that Te Rauparaha casts over Raukawa-Toarangatira and wider Maori and Aotearoa New Zealand history. Tamihana and his wife Ruta had no biological children of their own. Who then memorialises their memory? 


\section{Introduction}

Tamihana Te Rauparaha's manuscript about the life of his father is a compelling biographic text which provides fascinating insights into key events which shaped the nineteenth-century history of Ngati Raukawa and Ngati Toarangatira. In the close reading which follows I hone in on one particular aspect of Tamihana's manuscript which has to date received little critical attention. I follow here the lead of Maori literary scholar Alice Te Punga Somerville, who, in analysing a short story written by Te Rangihiroa (Peter Buck) explores the different layers of stories which are interwoven around the text. At a crucial point in her process she explains:

The next step out is to tell a story about our writer. While the narrator tells the story of the telling of a story, the narrator himself is created by the writer. This is true even if this story is itself a form of memoir: as Wendt has reminded us, even writing about ourselves is a form of fiction writing. "I don't see much difference between fiction and non-fiction. It's all fiction - that's if you define fiction as something you make up...you invent and select...For me now, there is no difference between autobiography and fiction." 85 (2009: 72-73).

I take my own step out here, at this point in the thesis, to tell a story about the writer, Tamihana Te Rauparaha. Tamihana is at once the storyteller, narrator and historian of his account as well as being the son of his main subject, Te Rauparaha. Tamihana's manuscript thus provides an opportunity to consider what it means to write as an insider on multiple levels: not only is Tamihana Te Rauparaha an "Indigenous insider" belonging to the same Indigenous community as his subject about whom he writes, he is also the son of Te Rauparaha. What does it mean to write about the life of one's parent? One's grandparent? One's tupuna? What lessons might we learn today from Tamihana's example?

${ }^{85}$ Hereniko and Hanlon (1999: 91). 


\section{Tamihana within the narrative}

Tamihana Te Rauparaha begins his manuscript about the life of his father with two deceptively simple statements. He writes:

He pukapuka tataku tenei i nga mahi a te

Rauparaha nui, o tona itinga kau matua noa

$\mathrm{Na}$, tana tamaiti tupu ake na Tamihana te

Rauparaha i tuhituhi kei wareware

(Te Rauparaha 18?: 1).

Tamihana introduces the topic of his narrative followed by an authorial statement confirming himself as the writer. The order of these statements gives precedence to his father as the focus of the narrative, "te Rauparaha nui" (my emphasis) (Te Rauparaha 18?: 1) the famed, important and esteemed Te Rauparaha, over Tamihana as the author of the text. The authorial statement also draws attention to the relationship between the writer and his topic where "te Rauparaha" is repeated as Tamihana's surname. Expressions of Tamihana's relationship with his father weave in and out of his narrative beginning with his opening remarks quoted above.

After spending the first fifteen pages writing about Te Rauparaha's whanau, his early life to adulthood and military campaigns in Kawhia, Tamihana enters the narrative:

hoki tetehi i kohuru, haere tonu i taua ra ponoa Ka

tae atu ki Marokopa, ka whaiho toku whaea i reira

he taimaha i a au i roto ano koa au i te kopu e

tatana ki te whanau, me tahi atu whahine ranga

tira o Ngatitoa Ka mahue iho i Marokopa, Ka

(Te Rauparaha 18?: 16).

Tamihana explains that on the long journey from Kawhia to the southern parts of Te Ika a Maui, his mother, who was heavily pregnant with Tamihana at the time, was left at Marokopa along with some attendants. The reader learns about Tamihana for the first time within the narrative as an unborn child. It is remarkable that 
Tamihana enters the narrative at this extremely early, pre-birth stage in his life and provides a particularly fascinating example of the nature of Tamihana's relationship to his text: Tamihana is not merely a reporter, observer or researcher, he is a participant in many of the events that he recounts in multiple ways and forms and these are not always made manifest in ways that we might think obvious or in ways we might expect. In the above example, for instance, although Tamihana is not an active participant in the migrations to the south that his people undertook, his presence, albeit as a child in his mother's womb, is an important part of the narrative: Tamihana's impending birth is the reason for Te Akau being left at Marokopa while Te Rauparaha and the main group keeps moving.

The circumstances of Tamihana's actual birth are picked up a paragraph or so later where, after describing how Te Rauparaha and Ngati Toarangatira moved on to tangi for their ancestral homeland Kawhia atop Moeatoa hill, Tamihana writes:

No te mutunga o te tangi, katahi ka karanga atu

a te Rauparaha ki a Ngatitoa, haere koutou

ki a te Atiawha whanga mai ai i a au.

Ka hoki au ki te tiki i taku whaeneene e aroha [illegible]

ana au ki a ia, ki a te Akau

(Te Rauparaha 18?: 16).

Te Rauparaha instructs Ngati Toarangatira to go to the people of Te Ati Awa and wait for him while he returns to Marokopa to fetch Te Akau. Tamihana moreover reports that Te Rauparaha also said "e aroha ana au ki a ia, ki a te Akau" which suggests that Te Rauparaha was concerned for Te Akau's well-being and held Te Akau high in his affections. Te Rauparaha's actions, leaving her well-attended at Marokopa and of returning for her when the time was opportune support this. This is also the first instance in the manuscript where Tamihana gives his mother's name, Te Akau, and this leads to Tamihana giving a brief description of his mother and the circumstances of his mother and father's union:

Ko te ingoa tenei o taku whaea, no Rotorua tenei whahine 
he whahine roa, he ahua pai ki te titiro atu, $\mathrm{i}$

moe i a Hape i te tuatahi, ka mate a Hape, ka

haere atu ano a te Rauparaha i Kawhia nei ki Rotorua

ara ki roto Kakahi ki Motutawha hoki, ko

nga pa tenei i noho ai taku whaea, nona tungane hoki

enei pa, nona matua, No te taenga mai o te Rauparaha

ki Motutawha ka moea nei e ia hei whahine mana

riri noa nga teina o Hape, ki a te Rauparaha mo ta

ratou pouaru, hei aha mana ena riri a ena tutua

haere ana ia i a te whahine, a te Kau

(Te Rauparaha 18?: 17).

Tamihana explains that his mother was from Rotorua, that she was tall and fine looking and that her first husband was Hape. ${ }^{86}$ Te Rauparaha's coming from Kawhia to the pa of Te Akau's brothers and parents at Rotorua and marrying ${ }^{87} \mathrm{Te}$ Akau at the pa named Motutawha angered Hape's younger siblings. Tamihana adds that Te Rauparaha was not bothered by this anger his actions provoked in Hape's siblings. In recounting the circumstances pertaining to his parent's union, Tamihana further consolidates the nature of his own relationship to Te Rauparaha as well as his position within his account as both the narrator of the account and the son of the main subject. The reader simultaneously learns something of the bold, independent character of Te Rauparaha.

Tamihana mentions his own birth seven pages later in a single and rather understated comment that appears at the end of Tamihana's recollections of the battle which Te Rauparaha named "Te Motunui" and where the illustrious rangatira Te Hiakai and Mama fell:

Heoi, ko toku whanautanga, Ko Pukearuhe te ingoa o te

\footnotetext{
${ }^{86}$ Hapekituarangi was an ariki of Ngati Raukawa. Te Rauparaha took over the mantle of Hape's leadership upon Hape's death and married Hape's widow, Te Akau, as was the custom (Collins 2010: 28-29).

${ }^{87}$ That is, 'marriage' in a pre-Christian sense which is perhaps better conveyed in the English word 'union'. The word 'marriage' and its variants is particularly grating in English language interpretations of Maori languagae quotes but it is a difficult one to get around.
} 
kainga i whanau ai au he pa, no Te Puoho

(Te Rauparaha 18?: 24).

Tamihana mentions that he was born at a pa of Te Puoho named Pukearuhe before recounting a battle that occurred sometime previously. Tamihana's description of his own birth is remarkable more for its lack of fanfare than any exceptional circumstances. Tamihana makes much more of his mother being left at Marokopa while heavily pregnant than he does the event of his own birth. A probable reason for this disparity is that whereas the recollection of Te Akau being left at Marokopa advances the wider narrative, Tamihana's actual birth does not. Other more immediately important events of greater consequence to Te Rauparaha and the people of Ngati Toarangatira were afoot at the time of Tamihana's birth which goes some way to explaining his rather underwhelming mention of his own birth.

That Tamihana narrates events both prior to and around the time of his own birth, events which he could not possibly remember himself, indicates that he heard these stories relayed to him often enough to commit them to memory and later reproduce versions of them in his manuscript. As Angela Ballara notes, "all of Tāmihana's account of the events of the early 1820s must have been derived from stories told to him by his father and other elders, since he himself was either not yet born or still a very young child during them" (2003: 39). Ballara draws attention to the issue of personal verses communal memory. Whose memories does Tamihana relate if the events concerned are set before, around or soon after his own birth? At these early stages in the manuscript Tamihana describes what might be called "communal memories", that is, memories which derive from and are sustained by the community into which one is born.

While the many risks, battles, and other trials and tribulations that Te Rauparaha and his people underwent at this point in the history take precedence in the account, Tamihana does not write himself completely out of the narrative. In one episode, Te Rauparaha had a prophetic dream in which a hawk attacks him, and Tamihana recalls Te Rauparaha's immediate reaction: 
manu ra, Katahi ka maranga ake a te Rauparaha, i to raua

moenga ano, ko te whaereere ko taku whae nei, ko au e iti ana

ano i reira, Katahi a Te Rauparaha, Ka maranga ki runga ka

(Te Rauparaha 18?: 40).

Tamihana recalls that his father rose from his and his mother's bed and also notes that he himself was there and was very young at the time. Tamihana is present within the context of the narrative even though he again plays little part in the actual action that plays out. This is the first instance in the manuscript where Tamihana recalls events which obviously stem from his own memories or personal recollection. Tamihana's childhood can be tracked in the manuscript through examples such as those cited above and in a further example where Tamihana recalls that he was present at the battle "Nihomanga" as a child of approximately five years of age:

tetehi. Heoi tapa iho te ingoa o tenei parekura

e te Rauparaha Ko Nihomanga.

he rau te taurekareka a te tangata ko au hoki

tetehi tamaiti i roto i tenei taua kua haere tu au

ka rima pea akutau, otira he whakaaro noa Kaore

te maori e matau

(Te Rauparaha 18?: 47).

Tamihana's comment, "otira he whakaaro noa Kaore te maori e matau" (Te Rauparaha 18?: 47) is particularly interesting as Tamihana here makes a comparison between himself and his perceived non-Maori audience and infers that Maori did not count the age of a person according to years. This difference in outlook is mirrored throughout Tamihana's manuscript whereby, as the following discussion demonstrates, Tamihana's development from a baby into a child, a young adult and later still a grown man, can be tracked through the way in which he recounts events within the context of his manuscript.

After describing a series of journeys in which his father visited different locations where allied iwi and hapu groups were growing food during a season of 
relative peace, Tamihana recalls that he was by this time older and that he accompanied his father on these journeys:

atu ki Kapiti, Kua kau matua iti nei au, e haere tonu

ana hoki au i nga ope nei, Kaore au e mahue i taku

matua

(Te Rauparaha 18?: 74).

It is particularly noteworthy that Tamihana writes "Kaore au e mahue i taku matua" (Te Rauparaha 18?: 74) which suggests that although he was not left behind in this instance, he had previously been left behind by his father on such occasions. This also hints at the maturity that Tamihana must have reached by this stage and suggests that Tamihana had passed from being considered a child into the ranks of those who were of a useful age in such undertakings. This rather understated example again marks an important moment in Tamihana's own development without taking any focus away from the main narrative.

Although the frequency with which Tamihana appears in the narrative does not increase markedly as the narrative progresses, the extent to which Tamihana participates in the action as well as the time Tamihana spends writing about his involvement in the events as they unfold does noticeably increase. Tamihana progressively recounts events more directly from his own perspective and reflects on the events as he recalls and understands them. The first example that stands out in this regard occurs when Tamihana relates a particularly harrowing accident where Tamihana, his brother Matata and Matata's wife suffered serious burns:

Ka tahuri ke te kanohi o taku tuakana Ka toro atu taku ringa ki nga paura, Ka riria mai e taku tuakana Ka pepeke mai taku ringa Katahuri atu Ka toro atu ano taku ringa ki te tiki atu i nga paura, No tetehi toronga atu oku Katahi ka nga horo nga paura ki runga i te ahi, Ka mura atu ki era e Kariritia mai ra e 
taku tuakana, Katahi ka whera matou i te ahi

(Te Rauparaha 18?: 110).

Although Tamihana was still a young child at the time, "he tamaiti rawha hoki au" (Te Rauparaha 18?: 110), the incident must have made a lasting impression on him, literally due to the burns on his body, and mentally, as evidenced by the detail with which he recalls it. Tamihana's direct involvement, indeed he is the cause of the problem, "Nui rawha te pouri o to maua matua kia au o te Paraha mo taku tahunga ia matou" (Te Rauparaha 18?: 110), no doubt also played a part in Tamihana's vivid memory of the event.

Clearly, Te Rauparaha was not at all pleased with Tamihana over his actions which led to Tamihana, Matata and Matata's wife being injured, "Nui rawha te pouri o to maua matua kia au" (Te Rauparaha 18? 110). Additionally, Tamihana notes Te Rauparaha's close proximity to the event "ko te Rauparaha he whare ano tona, metahi ona tangata he whare ano i tai tata atu i to te Paraha" (Te Rauparaha 18?: 109-110). The inclusion of both Te Rauparaha's reaction and close physical proximity to the incident illustrate Tamihana's positioning of the incident in direct relation to Te Rauparaha.

Moreover, Tamihana reflects on the behaviour of inquisitive children in general and makes a keen observation about how such children do not pay attention to the instructions of adults but rather "learn the hard way" through hurting themselves:

mo taku tahunga i a matou, he tamaiti rawha hoki au e tae te aha te tamariki tutu, ako rawha mai nga pakeke kia ata noho no whea e whakarongo atu, no te wheranga i te ahi Ka rongo i te mamae kaue katahi ka whakaaro e ka tahi te mea kino he kapa he tutu mei whakarongo atu pea ki te ako mai a te matua kua pai, penei kihai i rongo i te mamae (Te Rauparaha 18?: 110). 
Tamihana reflects on his own actions as a somewhat precocious child who certainly did, at least in this case, learn his lesson "the hard way". Through Tamihana's recounting of this incident the reader learns something of the precocious nature that Tamihana had as a child was as well as something about the nature of the relationships that Tamihana, his brother Matata and Te Rauparaha shared. Te Rauparaha's reaction to the incident of his sons and daughter-in-law suffering burns reflects the emotions of a parent who is themselves hurt or suffers at witnessing the pain of their children.

The second major example in the manuscript where Tamihana recounts events in which he himself was involved centres around Tamihana and Matene Te Whiwhi's journey to Te Waipounamu to preach Christianity to their relations there and to the people of Ngai Tahu. ${ }^{88}$ At this time Tamihana and Te Whiwhi would have been young men:

$\mathrm{Na}$, no to maua haerenga atu ko Matene te Whiwhi ki te

Kawhe atu $\mathrm{i}$ te rongopai, ki nga whahi i noho ai nga tangata

o Ngaitahu, Ka riri mai a te Rauparaha kia maua kia

kaua e haere ki Ngaitahu ki te ra motu, kia puta rano

tana aitua kia tae tana ope ki Rakiura, ki Otakou

Kihai hoki i whakarangona atu e maua nga riri mai

a to maua matua, Otira he tupuna ki taku hoa a te Rauparaha

Haere ana maua i runga i te poti, tae atu ana maua

ki Potikupa, ki Whangaroa, ki Moerangi ki Otakou ki

Ruapuke, whakapono katoa nga tangata o Ngaitahu puta

noa ki te kupu o te Atua pono o te Rangi, Ka hoki mai ta

ku hoa i Ruapuke ko au i haere atu ki Rakiura ki

Rarotonga ki Ngawhakaputaputa ki Tikapu te Rewha

ki nga whahi katoa o reira, Ko te ui kau mai a

nga rangatira o Ngaitahu kia au, e kore ranei to

matua e haere mai ki te patu ia matou ki te

88 Oliver gives the year for this journey as 1843 and notes that it was in November 1839 that Tamihana and Te Whiwhi travelled to the Bay of Islands to seek a missionary for the Kapiti area (1990b: 507508). 
tango hoki i to matou whenua, Ka ki atu au

Kaore e kore rawhaia e haere mai kua tae mai

nei hoki au kia koutou whakamutu ai i te whawhai

kia mau ai hoki te rongo taketake i runga i te korero

o te rongopai o te Atua, Koia ano whakapono katoa mai

nga rangatira o Ngaitahu ki taku korero, kotahi tau

oku ki Murihiku, ki Rakiura hoki ana mai au ki

toku kainga ki te kainga o taku matua o te Rauparaha

ki Kapiti.

Heoi ano ko te korenga rawhatanga tenei o te whakaaro

haere o te Rauparaha ki a Ngaitahu, Kua tae nei

maua ki te whauhau i te rongo kia Ngaitahu ki te ra pito o te

ra motu o te Whaipounamu.

(Te Rauparaha 18?: 113-114).

This is the first example in the manuscript where the reader encounters the young man Tamihana and glimpses a different kind of relationship whereby Tamihana asserts his own identity and goes against the wishes of his father. Tamihana explains that Te Rauparaha was angry with him and Te Whiwhi and did not want them to visit the people of Ngai Tahu. This antipathy on Te Rauparaha's behalf is understandable in light of the considerable dangers inherent in such an undertaking. Hilary and John Mitchell note that Tamihana and Te Whiwhi's missionary journey to Te Waipounamu was, "an intrepid expedition given the physical challenges and his father's recent exploits in the area" (2007: 122). Travel between Te Ika a Maui and Te Waipounamu across Raukawa moana was by no means an easy matter and moreover Te Rauparaha had only recently conducted conclusive military campaigns in Te Waipounamu which had decimated the populations in that island. ${ }^{89}$ The concern of Te Rauparaha as a parent or elder of both Tamihana and Te Whiwhi

\footnotetext{
${ }^{89}$ Ngai Tahu historian Te Maire Tau notes that Natanahira Waruwarutu who was present as a child at the time remarked in regards to Te Rauparaha's second attack on Kaiapoi pa, "Ka tahuri te riu o Te Waka a Māui ki raro" (The overturning of Māui's canoe, the South Island) (2011a: 24). Tau observes, 'To call Te Rauparaha's invasion of the South Island 'the overturning of Māui's canoe' signifies how considerable this events was - how the world of Ngāi Tahu would be utterly changed' (2011a: 24).
} 
would have been very real and immediate. The length of writing that Tamihana takes in relating his and Te Whiwhi's journey, however, some 29 lines of manuscript text, mirrors the development in Tamihana's personal growth at this stage in his account which saw him go against the wishes of his father.

Te Rauparaha's influence continues to be felt even though Tamihana and Te Whiwhi take matters into their own hands. Again, it is important to note that although Tamihana relates an episode in which he himself features, he does this in relation to Te Rauparaha. Tamihana writes that Ngai Tahu rangatira ask him about Te Rauparaha's intentions in regards to making war against them and seeking control over their lands (or taking their lands by conquest). Tamihana allays their fears and replies that he has come among them to bring about peace and the cessation of hostilities in the name of the Christian god. The Ngai Tahu rangatira are apparently reassured by Tamihana's reply and the matter rests there.

At this point the manuscript subtly changes tone: Tamihana no longer relates korero about Te Rauparaha based on korero which must have been passed on to him from his elders and instead relates events from his own personal perspective. Ballara notes this change in Tamihana's style as his story proceeds and argues that, "his accounts of the 1830s, particularly of events in which he himself participated as a teenager, have quite a different tone from the set-piece stylised dramas of the earlier period" (2003: 39). To illustrate her point, Ballara compares Tamihana's account of the escape of his father, himself and their kin from a beach near Kaparatehau in Cloudy Bay in about 1834 with his account of the battle of Waiorua which took place on Kapiti Island about 1824, at which Tamihana would have been about three years old. Ballara asserts that whereas the 1834 account is so vivid "that one can almost smell the sweat and terror and feel the exertion of their efforts to keep offshore", "his account of the battle of Waiorua ten years before is almost completely fiction, and is recounted as a stylised attack and defence, a set-piece battle modelled on many such accounts of wars in past tradition (2003: 39-40). ${ }^{90}$ Importantly, Ballara adds, "To

\footnotetext{
${ }^{90}$ Ballara adds, 'This is not say that Tamihana was not given this version of events later by his elders; he probably was. But 'traditions' have a way of growing, even if only by the wish of the narrator to make a fine story' (2003: 40).
} 
doubt Tāmihana's detailed account of Waiorua is not, however, to doubt the broader facts that he related; there was a major battle on Kapiti which was won by Te Rauparaha's side, and the protagonists included those groups he named" (2003: 40).

Although Ballara's overall observation is good her explanation is limited. Ballara contradicts herself by calling Tamihana's account "a complete fiction" while simultaneously asserting that "the broader facts" are true. Tamihana relates events from his perspective as a rangatira of Ngati Toarangatira and Ngati Raukawa as indeed should be "expected". The "set-pieces" he recalls outline the broader context of what happened according to the history and the present state of the tribe whereas his eyewitness accounts enable him to draw on his own personal experiences and give the reader a sense of what it was like to actually be there and actively participate in the events. What results is a complex interweaving of tribal history, personal recollection and memory which is brought into sharp focus by the shifting perspectives which are woven into the narrative.

Tamihana progressively relates events as he remembers them from his viewpoint and in relation to his own location and activities. At the end of the description of his and Te Whiwhi's preaching activities in Te Waipounamu for example, Tamihana recalls that he was in the Murihiku-Rakiura area of Te Waipounamu when the incident at Wairau took place. ${ }^{91}$ Tamihana furthermore explains that he had heard the conflict at Wairau was related to Pakeha who surveyed the land there:

I rongo au ki nga korero o taua whawhai, te take he ruritanga na nga pakeha i te whenua, Ka kite nga tangata maori, ara a te Rauparaha a te Rangihaeata, Ka whakakahoretia te ruritanga (Te Rauparaha 18?: 114).

Tamihana's shifting perspective continues to underscore both his views and knowledge as an individual as well as a member of the wider collective groups to

\footnotetext{
${ }^{91}$ For more on what has variously been referred to as 'the Wairau masacre' 'the Wairau affray', 'the Wairau incident' and 'the Wairau conflict' see Collins (2010: 150-177).
} 
which he belonged. Although Tamihana was not with Te Rauparaha at Wairau, he had heard what had happened and had formed his own views on the events there as they had played out. Tamihana reports on events based around his father Te Rauparaha regardless of whether or not he was himself present. Further, even though he did not always agree with his father and indeed, as the above example shows, was independent in many respects, the high esteem and respect that Tamihana accorded his father is constantly made manifest throughout the course of the narrative. Towards the very end of the manuscript, for example, Tamihana Writes:

Tenei hoki tetehi kupu he rongo tonu noku ki nga rangatira

kaumatua ona iwhi ki Kawhia, ki Maungatautari,

ki Rotorua, ki Tauranga, ki Hauraki, kia Ngapuhi hoki

kia Whaikato, kia te Atiawha, e kiana kaore kau

he kau matua hei rite mo te Rauparaha te mohio

ki te whawhai, me te toa hoki, me te tino tangata ki

te ata whai tangata aha koa mano noa nga rangatira

o te motu nei, kihai rawha i rite kia te Rauparaha

(Te Rauparaha 18?: 118).

Tamihana extolls the chiefly virtues which Te Rauparaha possessed, namely, "te mohio ki te whawhai, me te toa hoki" (Te Rauparaha 18?: 118), prowess in warfare and, "te ata whai tangata" (Te Rauparaha 18?: 118), the ability to care for those under his patronage. Tamihana dually grounds these virtues in a land-based tribal framework through naming the areas of Kawhia and Maungatautari, thus drawing on Te Rauparaha's Ngati Toarangatira and Ngati Raukawa whakapapa, and furthermore going on to name the areas of Rotorua, Tauranga, Hauraki, the tribe of Ngapuhi, the area and affiliated tribes of Waikato and the tribe of Te Ati Awa. Through naming his father's tribal and land-based affiliations and alliances, Tamihana constructs a whakapapa which supports his claim of the importance of Te Rauparaha. 
From prior to the event of his own birth Tamihana the writer positions himself in relation to Te Rauparaha and throughout his manuscript claims a specific and close relationship with his father. This position changes throughout the manuscript as Tamihana's own growth and development tracks alongside the life of his father. The varying positions that Tamihana adopts suggests a way of reading and writing that takes into account the relationship of the writer to the subject of their writing but which dually allows for complex interweavings of place, time and context. Tamihana states his relationship to the main subject of his manuscript within the narrative and reiterates the terms of their ever changing and developing, dynamic relationship at particular moments throughout the manuscript. Tamihana's manuscript thus challenges and extends how we think about biography, history and writing and blurs the boundaries between these genres. Tamihana's manuscript represents a unique opportunity to re-make and re-imagine these genres as well as the relationships between them.

\section{Tamihana the writer}

In order to explore the notion of Tamihana as a writer, I return to his authorial statement written on the very first page of the manuscript:

\footnotetext{
$\mathrm{Na}$, tana tamaiti tupu ake na Tamihana te

Rauparaha i tuhituhi kei wareware

(Te Rauparaha 18?: 1).
}

As Tamihana asserts that he wrote the manuscript he also clarifies the reason why he wrote it: "kei wareware" (Te Rauparaha 18?: 1). While it is likely that George Grey either commissioned Tamihana to write the manuscript or convinced him to write it as a personal favour, Tamihana's statement here centres his own reasons for writing an account of his father, "lest it be forgotten". An episode recorded near the end of 
the manuscript in which a Captain Blenkinsopp 92 attempted to defraud Te Rauparaha of his lands in the Wairau demonstrates that Tamihana was well aware of the far-reaching power of written documents:

No taua wha ka kite hoki tetehi rangatira Kaipuke o Ingarangi, o

Poihakena ranei, a Kapene Piringitapu, i te pai o Whairau Ka titiro rapea ki te ahua pai o te whenua, Ka ki mai kia te Rauparaha, no whai tenei kainga Ka ki atu a te Rauparaha Noku. Ka mea mai taua rangatira Kapene Piringatapu moku tenei kainga. Ka ki atu a te Rauparaha kaore, e kore e tukua atu e au, Ka tohe mai ano taua pakeha, moku taihoa e hoko e au kia hoki mai au i tawhaki i Poihakena, ka utu ai erangi taku pu nui, me whaiho iho kia koe hei taunaha mo Whairau, heoi ano ka kawhea mai te pu ki uta taka tonu atu ki roto ki te whai i runga i te poti i titaha te poti, Katahi Ka tuhituhia e Kapene Piringatapu nga pukapuka whakaae mo taua kainga mo Whairau kia riro ia ia, ko tana pu nui i taka ra ki te whai te utu mo Whairau, Ka tohutohu mai taua pakeha kia tuhia nga ingoa, Kaore i mohiotia atu ka tuhia ano e ia e taua Kapene Piringatapu nga ingoa o te Rauparaha ma Ka ki mai a Piringatapu kia te Rauparaha, Ka kite koe i te kaipuke manuao e rere mai ana ki konei, e tae koe ki runga ka hoatu kia kite te rangatira i taua pukapuka kia mohio ai te rangatira o te manuao he rangatira koutou Heoi ano ka koa nga tangata mau ia ua pukapuka No te taenga mai ki Kapiti nei o te Rauparaha i te Raumati i te wha kua riro atu nga kaipuke patu whera, No te hoatutanga ki tana pakeha hoko muka mana e korero mai nga tikanga o roto o aua pukapuka i tuhia ra e Kapene Piringatapu, Ka korerotia e taua pakeha Ka mutu ka ki atu a te Rauparaha, he aha te korero o tenei

\footnotetext{
92 Burns notes that there are different versions of this story as of the spelling of Captain Blenkinsopp's name (1980: 186).
} 
pukapuka, he mea moku kia kia ai au he rangatira nui kia mohiotia ai e nga rangatira manuao, Katahi taua pakeha

Ka ki mai, Kahore tenei te korero o te pukapuka, erangi ia

ia hokohoko te whenua Whairau, Kotahi te Pikikana te utu tenei

whenua katoa, Katahi ka pouri a te Rauparaha, whahia

iho taua pukapuka tahuna atu ki te ahi me nga mea

hoki ia te Rangihaeata ma, tahuna katoatia atu ki te ahi

haere tonu atu taua pakeha ki tawhahi kihai i hoki mai

ngaro tonu atu, ko te rironga tenei Whairau i kia nei i hokona atu ki te pakeha

(Te Rauparaha 18?: 103-104).

According to Tamihana, Captain Blenkinsopp drew up a deed of sale for Wairau, giving a canon which had fallen into the water as payment, and signed Te Rauparaha and the other chiefs' names to the document. ${ }^{93}$ Blenkinsopp tells Te Rauparaha that the deed of sale is a document that confirms his and the other chiefs' status as rangatira to visiting foreign vessels. When Te Rauparaha returns to Raumati he asks the Pakeha with whom he trades dressed flax to explain the meaning of the document, "No te hoatutanga ki tana pakeha hoko muka mana e korero mai nga tikanga o roto o aua pukapuka i tuhia ra e Kapene Piringatapu" (Te Rauparaha 18?: 103-104). The Pakeha trader explains that it is a deed of sale selling the lands of Wairau to Blenkinsopp in exchange for one big gun. Te Rauparaha reacts to this news by throwing the deed of sale and other documents in the possession of Te Rangihaeata and other chiefs into the fire and burning them. Te Rauparaha's immediate and forceful response of throwing not only the deed of sale but other documents in the possession of the other chiefs into the fire demonstrates the strength of his feelings in regards to both the legitimacy and worth of the documents. Tamihana writes that Te Rauparaha burned all of the documents literally to ashes, "tahuna katoatia atu ki te ahi" (Te Rauparaha 18?: 104). What we learn of Blenkinsopp following this episode is also very telling. Tamihana writes that

\footnotetext{
93 Turnbull and McLaren note that deeds such as these were rough copies of English legal documents which were 'improvised from a mixture of English land laws and Maori tribal laws'. They write that 'Neither party to the deal could be expected to understand what the other meant by it' (1964: 41).
} 
Blenkinsopp continued on his way overseas never to return, "haere tonu atu taua pakeha ki tawhahi kihai i hoki mai ngaro tonu atu" (Te Rauparaha 18?: 104). The inference here is that Blenkinsopp heard of Te Rauparaha's reaction and was too scared to show his face in those parts again. Tamihana then comments rather ironically, "ko te rironga tenei Whairau i kia nei i hokona atu ki te pakeha" (Te Rauparaha 18?: 104). This parting remark suggests that these are the terms by which Wairau was said to have been so "sold" to the Pakeha. Tamihana foreshadows the troubles which would later erupt over the sale of Wairau and which would ultimately end in bloodshed for both Maori and Pakeha.

The danger inherent in this episode, of unwittingly agreeing to the sale of a vast estate in exchange for what was essentially a trifle, was obviously not lost on Tamihana. A further example that gives some clues as to Tamihana's understanding of the potential implications of the written word appears eleven pages later:

\footnotetext{
Ka nui haere te pakanga a te Rangihaeata kia te Kawha

na, Ka nui haere hoki nga korero tito o nga tangata

me nga pukapuka tuhituhi a nga tangata hei whaka

pae ia te Rauparaha, Kua hara a te Rauparaha i runga

i te whakapae tika, Kua mutu tona aroha ki ona hoa

pakeha, kihai marama te maunga o te he o te Rauparaha

korero kau.
}

(Te Rauparaha 18?: 115-116).

Following Tamihana's description of the major incident at Wairau in which four Maori and twenty-two Europeans were killed, he describes the troubles that erupted over the sale of land in the Hutt Valley. According to Tamihana, as the aggravation between Governor Fitzroy and Te Rangihaeata increased so too did the fabrications, lies and accusations directed against Te Rauparaha both via word-of-mouth and even more importantly, in print. Tamihana notes that due to his being so publically judged and castigated despite siding with the Paheka, Te Rauparaha became disillusioned with his Pakeha friends. This example shows that Tamihana was conscious of the potential for the written word to be manipulated to suit particular 
agendas and to meet certain ends. Tamihana was also aware that the results of these types of actions could be extremely detrimental to those involved and today would surely be tantamount to defamation or worse.

The examples cited above confirm that Tamihana was cognisant of some of the ways in which the written word could be used and manipulated. This leads me back again to the beginning of the manuscript where Tamihana gives his reason for writing the manuscript:

$\mathrm{Na}$, tana tamaiti tupu ake na Tamihana te

Rauparaha i tuhituhi kei wareware

(Te Rauparaha 18?: 1).

Tamihana wrote against a tide of English language texts, Pakeha authored texts and Government authored texts that at the time, and still do today, receive more public attention than Maori authored work. Tamihana may therefore have felt some compulsion to write his own account of Te Rauparaha's life in order to counter the other narratives, rumours and lies about Te Rauparaha that were circulating at the time many of which have persisted well into the present day. Ballara notes that Te Rauparaha received a wave of condemnation in print because many of the early visitors to the Kapiti coast and Cook Strait who published accounts of the area were associates of the New Zealand Company. She writes:

Te Rauparaha was at the same time the Company's greatest obstacle to its landsharking plans and the source of its claim to have purchased a vast area of both North and South Islands. But he and his nephew, Te Rangihaeata, repudiated most of the deals the New Zealand Company said it had struck with him, so it lost no chance to blacken his name in print and ascribe to him all the ills experienced by Company settlers. He was 'cunning', capable of 'unbound treachery', and demonstrated the 'savage ferocity of the tiger' and the 'destructive ambition of a selfish despot', fond of 'slaughter' but at the same time 'cringing' and 'fawning'. In 1839 the Company set the example that Crown land purchase officers and other officials were to follow in the 1840s. The result was that one of the most skilled and daring war leaders the country has produced, and one of the Māori leaders who 
most successfully fought for the survival of his people and provided for them in the future, has been vilified by such epithets in the literature ever since. [ ${ }^{*}$ Except by Patricia Burns in Te Rauparaha, A New Perspective, Wellington, 1980.\} (2003: 34).

Tamihana's comment that he wrote the manuscript "kei wareware", "lest it be forgotten" (Te Rauparaha 18?: 1) takes on a whole new significance when viewed against the context described by Ballara and can furthermore be read as an expression of intellectual sovereignty. That Tamihana states that he wrote his account "Lest it be forgotten" suggests that he was motivated to write his version of his father's life in order that it be added to the record and contribute to the literature on Te Rauparaha's life. Tamihana's account provides an alternative version to the tide of non-Maori literature which was being produced at the time in contemporary periodicals, personal journals and diaries, official despatches and more about Te Rauparaha or in which Te Rauparaha featured, many of which perpetuated the overwhelmingly negative discourse constructed by the New Zealand Company. Tamihana's text can be understood as an early "writing back" to anti-Te Rauparaha literature and as an insurance against Maori versions of the story of Te Rauparaha being entirely absent from the written record.

Furthermore, Tamihana's manuscript can itself be viewed as an object of contention. I return full circle here to a note on the front cover of the manuscript book which reads:

History of Te Rauparaha written by

his son Tamehana Te Rauparaha

at his fathers dictation. Mr Travers

saw this and published in English

a summary of it

Photo of him and wife

GG

This small note has had far-reaching ramifications whereby generations of historians have taken it for granted that this manuscript was dictated to Tamihana 
Te Rauparaha by his father. ${ }^{94}$ In his note, Grey writes that Tamihana wrote the manuscript "at his fathers dictation" which suggests that Tamihana acted merely as a scribe who recorded Te Rauparaha's story. However, as the discussion throughout this chapter demonstrates, and as little more than a cursory reading of the manuscript will make obvious, Tamihana most certainly did not dictate the manuscript. The narrative in its entirety is written from Tamihana's point of view, in Tamihana's written voice and deserves to be remembered as the outstanding historic, literary work of art of one of our Raukawa-Toarangatira tupuna that it undoubtedly is.

\footnotetext{
94 See for example McRae (1997: 32) and Maclean who writes that Tamihana's version was based on his father's recollections (1999: 112). A notable exception to this is Burns who clearly considered the manuscript the work of Tamihana (1980: 12) while Collins writes a bit more ambivalently that the manuscript was said to have been dictated to him by his father (2010: 8).
} 


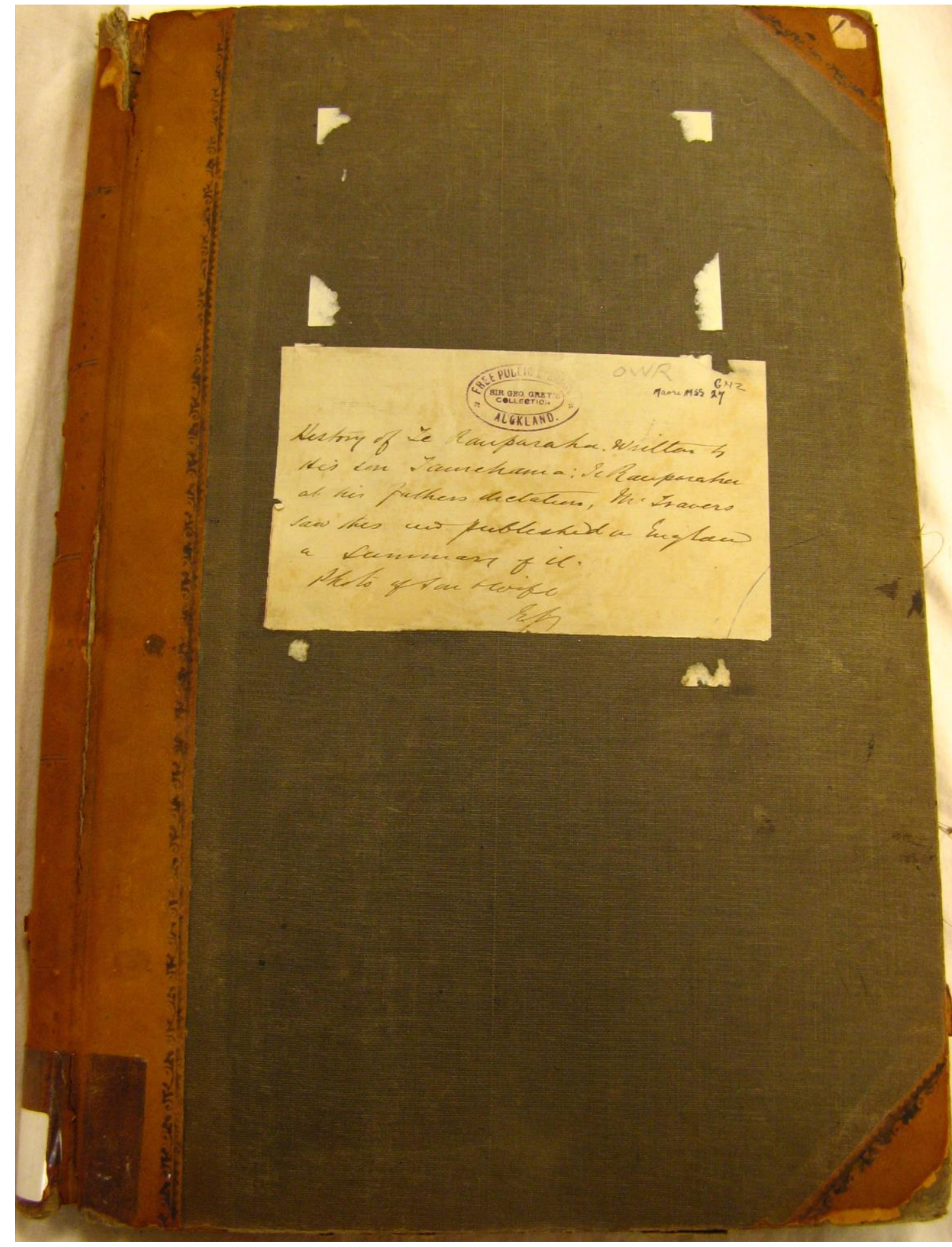

PHOTOGRAPH 1: THE FRONT COVER OF TAMIHANA TE RAUPARAHA'S MANUSCRIPT. 


\section{Conclusion}

Close reading of the way in which Tamihana Te Rauparaha is himself present in his text about the life of his father reveals Tamihana to be an author who does not shy away from the evidently close and warm relationship he had with the subject of his manuscript, his father, Te Rauparaha. Tamihana clearly articulates the shifting terms of their relationship as Tamihana himself develops within the context of his manuscript from a child to a man. The presence of Tamihana the writer is made progressively more evident as the events he relates move into his own contemporary times. As the narrative shifts further away from Te Rauparaha and closer to Tamihana we, the readers, witness the birth of Tamihana the writer. ${ }^{95}$ Tamihana's authorial agency is asserted throughout his account through the ways that he unselfconsciously relates events as he recalls them or recalls the stories of them as an author with his own unique perspective on the events which shaped and defined his father's life. Tamihana's account is articulate, deliberate and complex as befitting his birth right and position as a rangatira of his people.

${ }^{95}$ This recalls Roland Barthes's hugely influential ‘Death of the author' literary theory (1967). 


\section{POU TUARUA: SECTION TWO}

\section{Chapter Three: The invention of mythology: Sir George Grey's \\ Ko nga Mahinga a nga Tupuna Maori and Polynesian Mythology}

\section{He Korero}

Generations of New Zealanders have grown up with Peter Gossage's series of Maori picture books. I, myself, have fond memories of gazing over the attractive, brightly coloured pages of these books in my school library and having them read to us by the teachers in my early years at primary school. The series has been reprinted many times and so my own son has several of the titles available to him on his own bookshelf as well as at the primary schools he has attended and the local libraries he has frequented. A hard cover copy of In The Beginning was given to him as a gift by my Dutch cousin and this remained a favourite for many years. The books are simply written and the illustrations boldly drawn and coloured. The series has been available in both Maori language and English language versions although the Maori language versions are, at least in my experience, much more difficult to source. Through these and other books and media that I encountered throughout my childhood, I came to understand Maori stories as the stuff of wild fairy tales, of gods and demigods, mythical taniwha, fantastic feats and superhuman exertions. But what of the original composers and authors of these stories? Where did Peter Gossage get the stories?

I have a six-month old baby girl who I've watch grow and develop as I've worked on the final stages of this thesis. When I take her to visit the local library what books will we find? Will Peter Gossage's books be waiting on the shelves for her as they were for me and later for her brother? Or have new myths or new versions of myths been produced which describe our people and our lands?

\section{Introduction}

Maui-tikitiki-a-Taranga is more than simply a 'mythic' hero. For many he is a prominent figure in a long family line. The whakapapa that binds Maori to our 
tupuna is significant to the present and future, and carries with it the 'ultimate expression' of who we are (Mahuika 2009: 133).

Re-casting our ancestors as mythic heroes and, albeit to a much lesser degree, heroines, the stuff of fantasy and make-believe, is an expression of colonial mythology which overwhelmingly serves colonial ideologies and agendas. ${ }^{96}$ According to Toon van Meijl:

...as Māori became politically and economically subordinate to Pākehā, only their ideological colonisation remained to be accomplished. This was achieved in part through the collection of Māori traditions by ethnologists aided by Māori informants. Bilingual and literate Māori were essential to this process; they wrote a huge volume of information. From these oral and written Māori sources, Pākehā ethnologists rewrote and reconstructed the traditional stories with scant consideration for tribal variations, and presented tribal accounts as common to all Māori (1996: 322-3).

Mahuika similarly notes that our stories have often been subsumed by the academic discipline of History in its "idealistic pursuit of a supposed objective truth, complete with an underlying empiricism that has favoured written documents whilst denouncing oral sources as frail and unverifiable" and that such an approach "has regularly reduced our kōrero tuku iho to quaint tales, legends and fables" (2010: 25). This new literature has been served up to Maori and non-Maori alike over successive generations from as early as the 1850s. ${ }^{97}$ Thanks in no small part to the state-sponsored education system in Aotearoa New Zealand, generations of Maori and non-Maori children have grown up hearing and reading these "myths" and, for want of alternatives, passing them on to their own children. The perpetual erosion of Maori histories and beliefs, though perhaps less obvious than the more immediate

96 ` P. J. Gibbons has described the use of printed and written work as a sharp instrument of colonisation. He outlines what he calls the "strategies of textualization": first of all the indigenous cultural resources are "looted", for example, the indigenous nomenclature for flora and fauna or for features of the landscape is plucked from its own complex signifying system and appropriated; then there is the collection, translation and literification of "myths" which can be turned into fairy stories for the children of the settlers' (1986: 34) (cited in Garlick 1998: 20).

${ }^{97}$ McRae writes about a 'new literature' emerging from translations of the oral traditions. She talks about this being a literature 'retold' in English and mentions 'rewriting' by A. W. Reed and other 'Pākehā enthusiasts of Māori culture' (1997: 26). 
effects of land alienation, has been no less a violent assault on us as a people. Our intellectual heritage has been under attack since our first initial contacts with European peoples and these often subversive attacks continue today.

This chapter reviews two of the first publications which heralded the beginnings of the popular genre of "Maori mythology", Sir George Grey's Ko nga Mahinga a nga Tupuna Maori (1854) ${ }^{98}$ and his English language translation work, Polynesian Mythology and Ancient Traditional History of the New Zealand Race (1855). ${ }^{99}$ Grey's Nga Mahinga and Polynesian Mythology set the tone of what was to follow and were influential in establishing the literature as it followed over the next 150 years. ${ }^{100}$ Literary scholar Jane McRae notes that Grey was, "the first to decide how the oral texts, the form of songs, sayings and genealogies, should be laid out in print (1997: 25-26) while Alpers writes that, "Grey's original text of these stories has become a kind of Holy Writ" (1964: 242). ${ }^{101}$ Grey, however, edited Te Whiwhi's manuscript to conform to his own Euro-centric and pro-colonial gaze. ${ }^{102}$ Grey shaped Te Whiwhi's and other Maori writers' texts to suit a particular colonial framework and this contributes to ways that, as Mahuika puts it, "for Maori, the nation, rather than being a Frontier of Dreams, continues to be a site of oppression and marginalization, where our pasts are often relegated to peripheral sub-plots of the dominant national narrative, or even worse, appropriated altogether beyond our recognition and grasp" (2009: 134). Te Whiwhi's text is a literary representation of our past which has been so appropriated and up until more recently has lain beyond our grasp.

\footnotetext{
${ }^{98}$ Referred to henceforth in this chapter as Nga Mahinga.

${ }^{99}$ Referred to henceforth in this chapter as Polynesian Mythology.

100 This is so much so that Apirana Ngata argued that Nga Mahinga and Nga Moteatea provided the literature upon which a BA subject in the Maori language could be based (1972: vii; xiii).

101 Alpers rather eloquently goes on to explain his own use of Grey's work in his re-tellings of Maori myths, 'Its inconsistencies, up to a point, must for the meantime be preserved, as being essential to the art which they disfigure, like a Venus's broken arms' (1964: 242). Alpers is interesting for how forthright he is about the aims of his own work. He writes that his present work, 'is not the work of a Maori scholar; it is nowhere a new translation; it is based on English-language sources only, and where it attempts to correct mistakes it only tackles those more obvious ones that can be discovered by collating the English texts' (1964: 233).

102 See chapter two in my MA thesis 'Haere mai me Tuhituhi he Pukapuka; Muri iho ka Whawahi ai Tātou: Reading Te Rangikāheke' for a discussion of how Grey similarly edited Te Rangikaheke's manuscripts to suit his own agenda (Loader 2008: 35-57).
} 
This disconnection between Maori and Te Whiwhi's text applies literally due to Grey leaving the manuscripts in South Africa and their not returning to this country until the 1920s, and also more figuratively due to the manuscripts having lain "buried" in the archives ever since. ${ }^{103}$ In his article which alerts readers to the wealth of Maori material in George Grey's collection which was still at the time located in South Africa, H. W. (Herbert William) Williams writes that the Maori material had lain there "for over 40 years practically lost to Maori scholars in New Zealand, and for the most part undisturbed on the shelves of the fireproof room in which the collection was placed" (1906: 176) while Biggs notes that it was not in fact until 1922-23 following "protracted negotiations" that an exchange of material between the libraries at Cape Town and Auckland was carried out (1952: 177). While the manuscripts have been physically returned to Aotearoa New Zealand from their long sojourn in South Africa, the question of intellectual repatriation to Maori communities remains largely unresolved.

Non-Maori descriptions, accounts and narratives that have been produced about Maori such as Grey's Nga Mahinga and Polynesian Mythology tell our stories from a perspective which is not our own. While I do not subscribe to the view that the only way to tell Maori stories is from a Maori perspective, Maori perspectives on Maori stories are important and are currently, largely missing, or at least heavily disguised, in the published literature. The genre of Maori mythology, legends and traditions as represented in children's books, young adults fiction and the older texts of such writers as A. W. Reed all the way back to George Grey, thinly masks it own intents, influences and biases anchored in British colonial ideology and deserves to be unmasked and re-told again.

\footnotetext{
${ }^{103}$ Citing the example of Elsdon Best and his ethnographic work on Maori in the early twentieth century, Linda Smith notes that, 'while Best lives on as an expert, the names of his informants and the rest of their knowledge lie buried in manuscripts and archives' (1999: 85).
} 


\section{Nga Mahinga and Polynesian Mythology}

In 1854, Sir George Grey published Nga Mahinga, comprising a series of short narratives concerning the creation of man, legendary heroes and heroines, and episodes of the arrival and settlement of the ancestors in Aotearoa (McRae 1998: 13). Individual narratives are listed under such titles as 'Nga Tama a Rangi', 'Maui', and 'Rupe raua ko Hinauri'. This initial publication was a relatively small-scale, scholarly production and was paid for by Grey himself whereas Polynesian Mythology was published in 1855 by the prominent London firm of John Murray and made, what New Zealand literary scholar John O'Leary calls, "a formidable impact" (2008: 21-23). Polynesian Mythology was received enthusiastically across Europe with one anonymous reviewer in a Leipzig newspaper stating that Grey had opened up “a completely new field" (O'Leary 2008: 23). Scholarly opinion was no less positive with Professor Carl Schirren stating in a footnote in his book Wandersagen der Neuseelānder und der Mauimythos [Migration Legends of the New Zealanders and the Myth of Maui] that Grey's book held the "key" to the whole of Polynesian mythology (O'Leary 2008: 23). The general public was equally enthusiastic; Grey received letters of praise from readers and requests to use material in Polynesian Mythology for literary and musical purposes almost from the day of its publication (O'Leary 2008: 23). ${ }^{104}$

Ethnologist David Simmons calls Nga Mahinga "the most authoritative and representative collection of Maori traditions" (1966: 185) while historian Peter Gibbons writes that, "Polynesian Mythology became, and has remained, the locus classicus of local myths and legends" (1998: 42) and additionally notes that "nearly all subsequent published collections derive, in whole or part, directly or indirectly, from Grey" (1998: 42). Indeed, as Alpers notes, both Nga Mahinga and Polynesian Mythology, have, "with the emendations of later scholars...always been regarded as the principal source-books of Maori mythology in prose" (1964: 232). The success of

\footnotetext{
${ }^{104} \mathrm{O}$ 'Leary furthermore notes that 'Polynesian Mythology continued to exert an influence into the twentieth century with the Hinemoa legend providing the basis of New Zealand's first feature film, Hinemoa, in 1914 and the Maui stories inspiring such poets as Jessie Mackay and later, James K.

Baxter' (O'Leary 2008: 23).
} 
Polynesian Mythology was at least in part because it is entirely in the English language. Whereas Grey's first Maori language publication, a collection of waiata texts published under the title Ko nga Moteatea me nga Hakirara o nga Maori as well as Nga Mahinga had been small-scale, scholarly productions, read by perhaps no more than a few dozen readers and paid for by Grey himself, Polynesian Mythology was a commercial as much as a scholarly venture (O'Leary 2008: 21).

The relationship between Grey's Nga Mahinga and Polynesian Mythology, however, goes much further beyond simply that of a Maori language source text and its English language translation. The terms of this more unusual relationship are in fact suggested in their titles: there is nothing in the title Ko nga Mahinga a nga Tupuna Maori which translates as "Polynesian" nor is there anything which translates as "Mythology". The literal meaning of Ko nga Mahinga a nga Tupuna Maori is "The Deeds of the Ancestors of the Maori". These major differences hint at a whole raft of complexity, the ideological "clothes" of Penny van Toorn's assertion that Writing Never Arrives Naked (2006). The titles which Grey gave his works speak volumes about George Grey rather than the works themselves. Polynesian Mythology, for example, suggests that Maori are widely representative of Polynesian people as a whole. In the titles of these Maori books Grey blurs lines between ancient times, tradition and history.

The profound influence that Grey's Polynesian Mythology had both locally and globally, however, far exceeds its own design. Grey substantially edited and altered the source texts he used to produce Nga Mahinga which he followed by more editing and alterations in addition to questionable translation in Polynesian Mythology. In his article which examines the translation and publication of Maori material in the Auckland Public Library, Bruce Biggs notes:

What Grey does not tell us is that he took a great many liberties with the original texts, liberties which even when they added to the clarity of the story (and in many cases they do not do so), detracted from their value as accurate original versions of the traditions as told by the older generation of Maori experts (1952: 180). 
In his article Biggs goes on to identify three key ways in which Grey edited the manuscript texts and groups them under the following headings:

Rearranging and combining material from several sources to fill out the legends, and failing to indicate where this had been done ${ }^{105}$ (2) The omission of passages which revealed that the authors were familiar with European culture, and of passages which were evidently considered to be too strong for our cultivated tastes (3) The alteration of the construction of sentences which was indulged in freely, often making for awkwardness and sometimes obscuring the sense (1952: 180-181).

To this list McRae adds, "making additions and deletions to the manuscripts" and "failing to acknowledge his writers" (1998: 14). McRae summarises Polynesian Mythology's main failings and notes a further and much more subversive negative effect resulting from the publication:

The English version fails to convey the complexity of the Maori texts, their dramatic and poetic qualities, and expression of Maori values and custom, and, in the opinion of some, has had a somewhat unfortunate influence on New Zealand writers and on general knowledge and understanding of Maori oral tradition (1998: 13).106

Not only is the source text upon which Polynesian Mythology is based seriously contrived, the translation has itself been the object of serious criticism as outlined above by McRae.

Given both the amount and the seriousness of the criticisms levelled at Grey and his editing and translation work with Maori material, it is astounding that the bulk of the criticism that Grey's Nga Mahinga and Polynesian Mythology have received is couched in terms which excuse Grey for being no less than a product of his time. McRae, for example, writes that criticisms of Grey's work "have been made in light of improved methods of collecting oral history and of a more equitable exchange of

\footnotetext{
105 Williams notes this in his preface to the 1928 edition of Nga Mahinga (retitled Nga Mahi a nga Tupuna), 'Sir George Grey tells us that he has in some circumstances combined matter collected from different sources. Such combination may prove misleading, for there was generally a reason for the local variation' (Grey 1928: vii).

106 Comments on the influence of Polynesian Mythology can be found in Curnow (1960: 71) and in Alpers (1964: 5-6).
} 
knowledge between Maori and Pākehā" (1998: 14) while O'Leary writes that, "Such casualness on Grey's part should perhaps be seen in the context of his era, for at this time ownership of cultural materials by indigenous peoples was rarely, if ever, recognised" (2008: 21). ${ }^{107}$ Even Biggs takes a milder view when he writes that, "Grey should be freed from Buck's charge of committing "literary atrocities for which there is no excuse"' (Biggs 1952: 178). The pervasive veneration that both Grey's Nga Mahinga and Polynesian Mythology continue to receive in the face of these and other serious criticisms is truly alarming as it removes any responsibility from Grey for his actions and, more seriously, excuses the manipulation of one culture's stories in order to serve the desires of another. When followed to its inevitable conclusion, this line of argument completely obliterates any sense of responsibility from everyone as everyone can use the excuse that they are merely acting as a product of their time.

Alpers takes a slightly different view and considers Grey's editing work in both Nga Mahinga and Polynesian Mythology alongside his work of collecting and preserving the original manuscripts. While Alpers notes that "Grey made many alterations, in both of his editions, to the material he was given, and by today's standards his work as a collector is open to severe reproach" he adds that "he is saved, however, by the fact that he carefully preserved the manuscripts of his 'chiefs and priests', and they still exist" (1964: 232). Rather than passing Grey's intrusive editing as Grey simply being a product of his time and circumstance, I agree with Alpers who asserts that Grey was wrong in his editing of the texts but are fortunate that he preserved the original writings.

To be clear, whereas both Nga Mahinga and Polynesian Mythology did represent a huge step forward in terms of the publishing of Maori traditions, they did so at the expense of quality and also of recognising that Maori have been largely

\footnotetext{
107 See also Kerr, 'The provenance of many of Grey's Maori manuscripts is lost, a situation exacerbated by the re-arrangement of individual sheets and volumes over the years. The difficulties surrounding the collecting of such materials, especially those grounded in an oral tradition, are immense, and one should forgive Grey both for certain lapses in recording provenance and for his failure to match twenty-first-century demands for full and proper documentation. It must be remembered that if not first in the field, he was certainly one of the earliest to collect this material' (2006: 80).
} 
excluded from the same enterprise. In short, in their defence of Grey's work many scholars have failed to take into account the seriousness of the wider implications that Grey's works have had on Maori people and Maori culture more broadly. The story of Grey's Nga Mahinga and Polynesian Mythology publications are complex and layered and the further one delves into this history, the more a sense of the importance of framing and shaping becomes apparent. Somewhat hidden amongst the story of Grey's publications lie the manuscripts, the texts without which Grey's publications could not have been created.

\section{Te Whiwhi's work in Grey's Nga Mahinga}

According to Simmons, Grey made use of three of Matene Te Whiwhi's manuscripts in the production of Nga Mahinga which, for want of better titles than the English language ones assigned them by Bleek $(1858 ; 1867)$ and Grey, are catalogued in Grey's collection as GNZMMSS 46, GNZMMSS 54, and GNZMMSS 77 (1966: 181-182). ${ }^{108}$ Under the heading "Ngati Toa, Ngati Raukawa and Waikato Sources" Simmons notes that Te Whiwhi was Grey's main source in the Horowhenua-Wellington area (1966: 181). ${ }^{109}$ Simmons credits Te Whiwhi with providing the source texts for "Te Patunga o Kae", most of the korero of "Tawhaki" and "Manaia raua ko Ngatoroirangi" and all of "Rata raua ko Whakatau" and "Whakatau raua ko Hine-i-te-iwaiwa" (1966: 181-182). Te Whiwhi is also credited by Williams as contributing part of the story of "Maui", a passage concerning the Moa in "Te Haerenga mai o Ngahue" and in "Te Korero mo nga Waka" (cited in

\footnotetext{
108 GNZMMSS 46, for example, is entitled 'Genealogies and Legends'. GNZMMSS 77 is entitled 'Two genealogies and one legend'. Both titles are not very helpful in describing the contents of the manuscripts. Simmons attributes GNZMMSS 77 to Te Whiwhi but closer inspection reveals it to be written in Grey's hand (1966: 181). GNZMMSS 77 relates the story of Tutunui and Ngae (Kae) and includes a note near the title at the top of the page, 'A whaha' ('a-waha') which suggests that Grey obtained the korero orally and either dictated it or wrote it down after hearing it.

109 Simmons refers to the 1928 (third edition) of Nga Mahi edited by Williams throughout his article rather than a $1^{\text {st }}$ or $2^{\text {nd }}$ edition. Simmons also writes that Matene Te Whiwhi obtained most of his information from Te Rangihaeata. He does not, however, say how he arrived at this conclusion and it seems likely that he, like many other scholars, was influenced by the notes that Grey made on the manuscripts.
} 
Simmons 1966: 181-182). Simmons additionally notes the insertion of paragraphs written by Te Whiwhi in a narrative by Te Rangikaheke concerning the Tainui canoe, “Te Hekenga Mai” (1966: 182).

As comparison with Te Whiwhi's GNZMMSS 46 and Nga Mahinga reveals, Grey split up the narratives into individual stories rather than presenting them, as Te Whiwhi does in his manuscript, as belonging to an integrated whole. Grey formed a patchwork of korero by various sources which hangs loosely together. In Grey's version of "Te patunga o Kae", the story of Tinirau and Kae, for example, Grey has the group of women led by Hineteiwaiwa and including Raukatauri, Raukatamea, Itiiti, Rekareka and Ruahauatangaroa, perform what can been interpreted as a sexually explicit haka. Grey writes, "Ka whakaaro ratou, "Me aha ra, kia kata ai a Kae?" Ka rapua e ratou he tikanga hei mamingatanga ma ratou i a Kae, a ka kitea. Na Katahi ka haka e ratou, koia tenei ta ratou haka" (1928: 30) and gives the words of the haka:

\author{
Ako au ki te kowhiti \\ Kaore te kowhiti \\ Ako au ki te whewhera \\ Kaore te whewhera \\ E kowhiti Nuku \\ E kowhiti Rangi \\ E kowhiti werewere \\ Puapua e! \\ hanahana e! \\ Tinaku ai.
}

(Grey 1928: 30).110

After the women perform their haka, Grey writes, "Mutu kau ano ta ratou haka, tino katanga o Kae i kata ai, na katahi ia ka mohiotia e ratou" (1928: 30) after which Grey

\footnotetext{
110 Timoti Karetu gives a synopsis of the story of Kae and Tinirau and the words of this haka with an English language translation (1993: 15-16).
} 
again takes up Te Whiwhi's version of the narrative. In his manuscript however, Te Whiwhi writes:

na te pirori katahi ano a Kae ka kata

(Te Whiwhi 1852: 33).

Williams gives the meanings of "pirori" as "roll along", "twirl round, roll, bowl" and "toy hoop" (1971: 284). Te Whiwhi writes that Kae laughed due to either some kind of acrobatics or other amusement involving twirling that the women performed. Grey scored this line out in Te Whiwhi's manuscript in pencil over the original black ink and wrote, "ka whakaaro ratou me aha ra kia kata a Kae ra" (Te Whiwhi 1852: 33). Te Whiwhi is clear in giving "pirori" as the reason which caused Kae to laugh and thus reveal his identity to Hineteiwaiwa and the other women but Grey instead gives the haka as the reason which caused Kae to laugh. It is unclear where or from whom Grey sourced the words of the haka. Through making such alterations and additions to the narratives, Grey constructed his own versions of the narratives which radically changes the meaning of the stories and how they are interpreted and reinterpreted today.

\section{Conclusion}

George Grey's publications Nga Mahinga and Polynesian Mythology have had a profound influence on the ways in which traditional Maori stories, histories, beliefs and customs have been analysed and interpreted ever since they were first published in the mid nineteenth-century. Grey, however, edited the Maori source texts to suit his own agenda in line with his own beliefs and imperatives. Although Grey gathered his source material from Maori who often in fact wrote their traditions themselves, Grey's resulting publications emerge as significantly mediated retellings which constitute the beginnings of a new literature of Maori traditions filtered through a non-Maori lens. I argue for the extension and expansion of what we currently understand to constitute our intellectual heritage as Maori of 
Aotearoa and this view is compelled by the written evidence produced by our ancestors. Rather than trying to make Maori fit the world as it currently is, I follow Mahuika (2009) and suggest that we reinvent the world as it is currently prescribed to fit Maori and that we recognise all the diversity and dynamism that there is to be found in te ao Maori.111

111 This perspective is influenced by debates in Pacific Studies. Edvard Hviding, for example, argues that, "interdisciplinary practice is about more than a methodological combination of existing academic disciplines, and that a successful interdisciplinary approach should cause the epistemological, methodological, and institutional boundaries between disciplines to be disturbed, even remade" (2003: 43). 


\section{Chapter Four: Reading whakapapa in Matene Te Whiwhi's 'Ko te korero tenei o Maui'}

\section{He Korero}

I remember our Aunty Maira as a little old lady with thick, milk bottle spectacles, a gentle if not a little croaky voice and ready smiles. I remember her happy disposition and her warm hospitality. Aunty's house in Island Bay was quite something else again and I hold many fond memories of visiting her there as a child. Aunty's house was full of beautiful taonga: books lined the shelves while ornaments of every description were permanently on display. Aunty's house in my child's eye was a treasure trove of mysterious objects in muted tones and hues, where the musky scent of history hung heavy in the air.

Aunty was generous to a fault. She was always ready with gifts for me, my brother and sister: a toy car, a coin purse, or perhaps even an alluring string of plastic beads. Aunty also gave away more personal gifts from her shelves, drawers and bureaus. As she advanced even further in years, Aunty let more of her personal possessions go to friends and family, museums and archives. Aunty's leadlight cabinet now stands in my parent's lounge while portraits which used to grace the walls of her house now hang at Waiwhetu marae. As I type these words, I'm wearing her engagement ring which she passed to my mother who passed it on to me. In time I'll pass this and other taonga on to my own children.

In addition to letting her own personal possessions go, Aunty passed on many taonga which once belonged to our Uncle Pirimi: Uncle's war medals are with the New Zealand Army Museum in Waiouru while a pounamu mere went to the Dominion Museum. Uncle's books have taken their own divergent paths. Aunty gave a selection of these literary taonga to my mother and I discovered them some years later in a dusty box hidden in the recesses of my parents' garage. These taonga have stayed with me ever since. Amongst these literary gems is a first edition of Apirana Ngata's Nga Moteatea and a third edition of George Grey's Nga Mahi a nga Tupuna. This copy of Nga Mahi a nga Tupuna was given to Uncle by my koroua, his brother, Kingi Tahiwi, and is inscribed on the inside cover, 'To Bim from Tak $1932^{\prime}$.

Uncle Prim and Koro Kingi shared an intellectual as well as a familial whakapapa and a part of their intellectual legacy continued on to Aunty Maira and further on to me through 
their books. How much further will this whakapapa extend and under what circumstances? What does this whakapapa show and how does it show it? And, perhaps even more importantly, what claims does this whakapapa make in relation to us, here and now?

\section{Introduction}

For Māori, the fabric that held the knowledge of the world together was whakapapa. Every 'thing' was related and all 'things' were held together by genealogical connections that eventually referenced back to the self (Tau 2001a: 137).

In his manuscript which is catalogued as GNZMMSS 46 at Auckland City Libraries and is also known by the title 'Genealogies and Legends', Matene Te Whiwhi wrote a complete account of a series of ancestors and their exploits beginning with the famous Polynesian ancestor Maui and ending with Whakatau. Te Whiwhi's account incorporates what can be broadly defined as three Maori literary genres: whakapapa (genealogy), korero (narrative) and karakia (incantation). In this chapter I explore the meaning of the whakapapa throughout Te Whiwhi's manuscript.

\section{Maui and Taranga}

Matene Te Whiwhi's manuscript begins with a whakapapa spanning nineteen generations from Runuku to Hine and Taranga, the parents of Maui Tikitiki o Taranga and his siblings:

Ko Hine ka moe a Hine ia Taranga

Ko Maui mua

Ko Maui roto

Ko Maui taha

Ko Maui pae 
Ko Maui Tikitiki o Taranga

(Te Whiwhi 1852: 4-6). ${ }^{112}$

Stories of Maui abound throughout the islands of Aotearoa New Zealand and further still throughout the islands that are scattered around Te Moananui-a-Kiwa, the Pacific ocean. ${ }^{113}$ Maui is often referred to as an archetypal mythological hero, a demigod and a Polynesian 'trickster' figure. ${ }^{114}$ The stories of his fantastical deeds have been drawn on extensively to provide the basis of numerous children's story books, ${ }^{115}$ other literary compositions including a graphic novel, 116 waiata and at least one major stage show (2005, Maui: One Man Against the Gods. Tanemahuta Grey, director). Maui has captured the imaginations of many over successive generations. The stories of Maui and other ancient forebears are sometimes referred to as "myth-templates" which guide and model appropriate behaviours. ${ }^{117}$

The whakapapa of Maui given above by Te Whiwhi, however, tells a much different story of Maui to those which we are now so accustomed to hearing, seeing, and reading. This whakapapa tells of Maui's descent from an ancestral line spanning some twenty generations to the atua themselves. The whakapapa also shows that Maui Tikitiki o Taranga and his four siblings Maui Mua, Maui Roto, Maui Taha and Maui Pae, are the offspring of Hine and Taranga. As suggested by the name Hine and later confirmed in the narrative that immediately follows the whakapapa, Hine

\footnotetext{
112 Although commonly written today 'Maui Tikitiki $a$ Taranga' (my emphasis), I will continue to refer to 'Maui Tikitiki $o$ Taranga' (my emphasis) as per Matene Te Whiwhi's manuscript.

113 Maori Studies scholar Peter Adds notes, 'Maui is an ancestral figure known throughout the islands of the Pacific. He is often remembered for his cheeky character, heroic feats and risky adventures.Tales of his exploits connect people right across the region, from the Solomon Islands in the west, to the Caroline Islands in the north and the Tuamotu archipelago in the east' (Adds 2012: 33).

114 According to Tamihana Te Rauparaha, Te Rauparaha was also known by the name Maui Potiki which connected him to this famous ancestor. See also footnote 67 in this thesis. Maui is also known by the names 'Maui tinihanga' and 'Maui nukurau tangata' which memorialise his trickster nature. 115 See for example Peter Gossage's How Maui Defied the Goddess of Death (1985); How Maui Slowed the Sun (1982); How Maui Found His Father and the Magic Jawbone (1980); How Maui Found His Mother (1975); The Fish of Maui (1990); How Maui Found the Secret of Fire (2005); and Maui stories in collections of children's stories such as in Gavin Bishop's Taming the Sun: Four Maori Myths (2004); Warren Pohatu's Traditional Maori Legends (2000); Robert Sullivan's Weaving Earth and Sky: Myths and Legends (2002); and Queenie Rikihana Hyland's Illustrated Maori Myths and Legends (2003).

${ }^{116}$ Slane and Sullivan (1996).

117 See Walker (1990: 11-23). Te Maire Tau notes that oral traditions transcend their role of being records of the past, to become the myths that communities use as a basis for functioning (2003: 258).
} 
is the mother of Maui and his siblings and Taranga is their father. 118 This understanding that Taranga is the father of Maui and his siblings makes sense in terms of the well-known story of the circumstances surrounding Maui's birth whereby he is said to have been stillborn and cast into the sea wrapped in the topknot of Taranga. In a style found all over the Pacific, Maori men traditionally wore their hair long and in topknots while women wore their hair shortly cropped.119 This circumstance is why Maui is also remembered as 'Maui Tikitiki o Taranga' as he does indeed appear in the whakapapa given by Te Whiwhi above. Unusually though, the dominant narrative that comes through children's stories and other popular media today is that Taranga is the name of the mother, rather than the father of Maui and his siblings. ${ }^{120}$

Understanding Taranga as Maui's father opens up a whole range of possibilities for thinking about the nature of relationships between fathers and their children. That the topknot was a part of the most sacred part of the human body and that Taranga is said to have cut off his topknot to wrap his stillborn son Maui in it, speaks volumes about the aroha that Taranga must have felt for his son Maui. The story of Maui and his father Taranga can thus provide a mythic template which highlights a loving, close and deeply meaningful relationship between a father and their child. This understanding makes the story of Maui's birth less of a story of an abandoned single mother and demonstrates that Maui's father was also actively involved in his life. Reclaiming our texts can provide models for understanding relationships which help empower and advance our people. This is not to say that reclaiming our written heritage will fix all of our problems, but it is to suggest that

\footnotetext{
118 Te Whiwhi writes: 'Katahi ano ka hoki ki tona matua ki a Taranga' (my emphasis) (1852: 6). See also, 'Ka ki atu a Hine te whaea o Maui Tikitiki o Taranga tikina he ahi i a Mahuika' (my emphasis) (Te Whiwhi 1852: 9).

119 Buck writes, 'The Maori followed the Polynesian custom of the men wearing their hair long and tying it in a large topknot' (1950: 284). Alpers notes that calling Maui 'Maui-tikitiki-a-Taranga', 'is very strange, because women in those days did not have topknots. The topknot was the most sacred part of a person, and only men had them' (1964: 30).

120 Peter Gossage's books clearly position Taranga as Maui's mother and Patricia Grace and Robyn Kahukiwa present Taranga as a woman in their work Wahine Toa: Women of Maori Myth (1991).
} 
there is value in turning to our traditions as our ancestors wrote them rather than as how they have been interpreted and constructed by others.

\section{Tawhaki}

In addition to appearing at the beginning of the manuscript, whakapapa are used within the body of the manuscript to link particular ancestors into the narratives as they unfold. Te Ahukaramu Charles Royal notes:

In the original manuscript[s], stories continue seamlessly one from the other and are joined by the use of whakapapa...Therefore, when one extracts a single story, one has to make a judgement as to the best way in which to sever the story from the fabric of all stories for the whakapapa that connects them together renders them in total as some kind of fabric. Perhaps the image of the spider's web is useful in approximating the experience of isolating just one story from the fabric of a number of stories (1998: 102-103).

Royal's fabric analogy is useful here as it draws attention to the weaving of korero in with one another to form a whole piece. When or if the stories are isolated it becomes increasingly difficult to see how they interrelate and one loses track of the overall picture. The whakapapa here act as a kind of binding agent which links the stories together to form one continuous, greater narrative of our ancestors.

The first instance where whakapapa links smaller narratives within the whole occurs on page twelve where Te Whiwhi ends his narratives about Maui and moves on to korero about Tawhaki. Te Whiwhi writes:

Ka mutu tenei. Ka timata ki

nga uri o Maui. Ko te Rupe ta te Rupe

Ko Titipao te Titipao

Ko Raropo ta Raropo

Ko Moaha ta Moaha Ka moe iate komahawhara

Ko Kaitangata Ka moe ia Whaitiri 
Ko Hema Ka moe ia Urutonga

Ko Tawhaki tona teina ko Karihi.

Ka haere tenei i nga mahinga a Tawhaki

Ko Hinepiripiri te wahine a Tawhaki. Ka

(Te Whiwhi 1852: 12).

The whakapapa given here connects a series of narratives about Maui to a series of narratives about Tawhaki. Maui and Tawhaki are shown to be related to each other and their stories furthermore exist on a continuum from the primeval parents Rangi and Papa to their respective contemporary contexts. Linking the stories of Maui and Tawhaki in this way foregrounds an intellectual tradition which is much larger and more complex than the sum of its constituent parts. Additionally, as one reads through the manuscript and the cycles of korero one becomes aware of the seeds of a much larger narrative being planted out. This is emphasised by the list of whakapapa which begins the manuscript and the list of whakapapa which ends the manuscript.

In addition to reading whakapapa such as this as being the genealogical glue which binds the narrative sections together, it is also productive to read the whakapapa as narratives in their own right. The beginning of the whakapapa signals a movement from the stories of Maui to a line which begins with his descendent Rupe and from Rupe travels in a direct vertical line of descent to Titipao, Raropo and Moaha. Moaha and Te Kowhara begat Kaitangata, Kaitangata and Whaitiri begat Hema, and Hema and Urutonga begat Tawhaki and his younger sibling Karihi. The whakapapa moves from relating a direct line of descent from Rupe to Titipao to Raropo, ${ }^{121}$ to drawing out horizontally to include both parents of Kaitangata, Hema, and Tawhaki and Karihi ending with Tawhaki's spouse Hinepiripiri. ${ }^{122}$ The whakapapa broadens out to include both spouses and siblings which hints at the complexity of the relationships upon which the narrative section which follows is

\footnotetext{
121 In his 1944 Nga Rauru a Toi lectures Apirana Ngata termed this type of whakapapa which recalls a descent line without listing the spouse "taotahi" (cited in Tau 2003: 35).

122 In his 1944 Nga Rauru a Toi lectures Apirana Ngata termed this type of whakapapa which states intermarriages in the lines of descent "whakamoe" (cited in Tau 2003: 35).
} 
based. The whakapapa establishes the relationship between Tawhaki and his brother Karihi which is to prove crucial further on in the narrative proper and dually lays out their parentage and direct line of descent through Hema, Kaitangata, Moaha, Raropo and Titipao to Rupe.

\section{Rata}

The second example in the manuscript where whakapapa is given as a means of linking the narrative sections together demonstrates the relationship between Tawhaki with Rata and joins their korero together in the greater scheme of korero tuku iho:

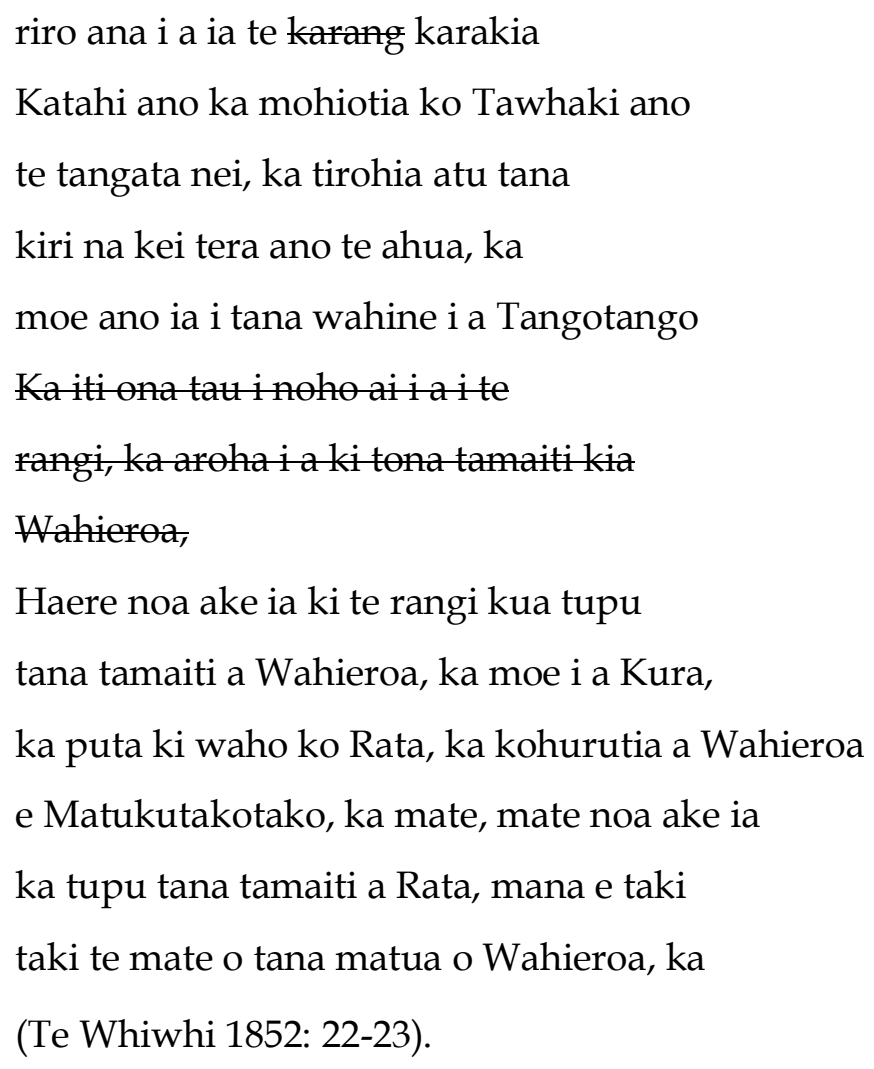

Although the whakapapa is not laid out in a list and rather appears in a narrative form its functions are similar to those of the previous example of whakapapa on page twelve of Te Whiwhi's manuscript. The whakapapa given here advances the broader narrative by marking the movement into a new cycle of korero based 
around Rata. The information given in this whakapapa link Tawhaki and Rata and their stories together and also, with the whakapapa and narratives given earlier, with Maui and ultimately with Rangi and Papa.

The whakapapa given here furthermore includes Matutakotako who is said to have killed Rata's father Wahieroa. Although Matutakotako is not included in the whakapapa as being genealogically related to Rata, Matutakotako is integral in the narrative which follows due to his (or her) action in killing Wahieroa leading Rata to seek utu. Matutakotako is in this way an important figure within the whakapapa of the narrative itself even and although he (or she) is not a member of the genealogical whakapapa: the whakapapa itself here functions as narrative. The whakapapa given at this point in Te Whiwhi's manuscript has important implications in terms of content which supersedes its narrative form.

\section{Whakatau}

The next whakapapa which is written into the manuscript, also in more of a narrative style, incorporates what appears to be an inanimate object into the genealogy of the famous tupuna Whakatau:

ake. Ka moe a Tongarautawhiri i a

Rata, Ka puta ki waho ko Tuwhaka

raro, ka moe i e Apakura, Ka puta ki

waho, Ko Whakatau, Ehara i te mea

$i$ whanau tangata mai, e ngari he maro,

No te haerenga o a Apakura ki tatahi

ka whiua tona maro ki te moana, ka

ahuahungia mai e Rongotakawiu, ka

tupu ko Whakatau, ka akona e tona

(my emphasis) (Te Whiwhi 1852: 28). 
Thus is an inanimate object, Apakura's maro or apron, spun into the complex web of relationships which underlies these narratives. Providing an answer as to whether or not all the tupuna named and discussed in this manuscript are mythological personages, historical characters, or something else is not the concern of this thesis suffice to say that the entities mentioned might be both or more. Maori scholar Te Maire Tau has argued that the storytellers of oral traditions "make no distinction between what the west sees as secular and spiritual worlds" (2003: 89) and moreover that "Māori see no clear demarcation line between the dead and the living, human and atua" (2003: 89). The whakapapa of Whakatau which Te Whiwhi relates above similarly challenges us to rethink how we conceptualise relationships between all manner of phenomena both animate and inanimate.

Further, a closer examination of the subtext underlying the story of Whakatau's parentage given above reveals a hidden, or perhaps more accurately "coded" narrative. Tuwhaka and Apakura are linked together in the whakapapa as spouses and yet a third person, Rongotakawiu, is incorporated into the raising of Whakatau. The notion of Rongotakawiu as a third person is crucial here. When we consider that maro covered the pubic area of the body, a different reading of this whakapapa is enabled which sees Whakatau as the illegitimate son of Apakura and Rongotakawiu. Apakura is said to have thrown her maro into the ocean after which it was tended by Rongotakawiu and subsequently raised to become Whakatau which poetically suggests that Apakura had sexual intercourse with Rongotakawiu which resulted in the conception and later birth of Whakatau. Rongotakawiu raised his son Whakatau alone, or at least, without Apakura. Te Whiwhi goes on to describe how Whakatau is ultimately reunited with mother which brings the story of Whakatau's parentage full circle. Whereas Whakatau is said to have been raised by his father Rongotakawiu, he reconnects with his mother in terms which reiterate the circumstances of his parentage:

Ko au tenei ko Apakura, Ka tu a Whakatau

ka mau nga ringa o Apakura ki a ia,

Ka ui atu ki a ia, na wai koe, ka 
ki atu a Whakatau, nau ano ra au,

ko to maro i whiua e koe ki te one nei,

na toku tupuna au na Rongotakawiu i

hanga, ka whakatupu tangata a hau,

Ka huaina toku ingoa ko Whakatau

(my emphasis) (Te Whiwhi 1852: 29).

In an interesting reversal to the common thread in Maori myth which sees a young man search for his father, Whakatau reconnects here with his mother. Similarly to the story of Maui which is radically altered when we read Taranga as being Maui's father rather than his mother, the wider implications of these different circumstances are considerable. The notion that Whakatau was of questionable parentage but was raised by his father rather than his mother, brings a whole different perspective to bear on Maori views on the terms of relationships between fathers and their children, or, in the case of Whakatau and Maui before him, between fathers and their sons.

\section{Hineteiwaiwa, Tinirau and Tuhuruhuru}

Following this narrative which recounts the circumstances of Whakatau's parentage and reconnection with his mother, the whakapapa in the manuscript returns to Apakura and across horizontally to her elder sister Te Kohu:

mohio ia ki nga mea katoa, te tuakana

o Apakura ko te Kohu, ta te Kohu,

ko Hineiteiwaiwa, ka moe i a Tinirau

ka hapu te tamaiti, ka whakamamae kaore

e puta ki waho, Katahi ka whakahuatia

te karakia,

(Te Whiwhi 1852: 30). 
Te Kohu is said to have begat Hineteiwaiwa who, with Tinirau, begat a child whom we later learn to be Tuhuruhuru. Te Whiwhi writes that Hineteiwaiwa experienced difficulties during Tuhuruhuru's birth upon which circumstance a karakia is recited. The whakapapa stops here at Tuhuruhuru's birth which echoes the difficult circumstances of his birth: the whakapapa literally cannot continue until Tuhuruhuru is born and neither can the narrative. The difficulties surrounding Tuhuruhuru's birth call for special intervention which takes the form of karakia. This special intervention is in turn echoed in the special form of language in which it is delivered in the highly poetic and stylised form of karakia. The karakia advances both Tuhuruhuru's birth and the narrative itself with both events culminating in the birth of Tuhuruhuru and the progression of the narrative on to the story of Tinirau and Kae.

\section{Raukawa-Toarangatira}

The whakapapa that appears at the end of the manuscript read very differently from those included at the beginning of the manuscript and the linking whakapapa throughout the main body of text. This whakapapa begins with Ranginui and cycles through different stages of the sky or night and then on to stages of day or light beginning with Aonui and Aoroa. This whakapapa draws a long, continuous line of direct descent from Ranginui to Hoturoa, the kaihautu or commander of the Tainui waka:
Ko Ranginui
Ta Ranginui
Ko Rangiroa
Ta Rangiroa
Ko Rangipouri
Ta Rangipouri
Ko Rangipotango
Ta Rangipotango 
Ko Rangiwhetuma

Ta Rangiwhetuma

Ko Aonui

Ta Aonui

Ko Aoroa

Ta Aoroa

Ko Aoweheke

Ta Aoweheke

Ko Aowetara

Ta Aowetara

Ko Te Uruhanga

Ta Te Uruhanga

Ko Te Hoehoe

Ta Te Hoehoe

Ko Taneitekapua

Ta Taneitekapua

Ko Puhaorangi

Ta Puhaorangi

Ko Ohomairangi

Ta Ohomairangi

Ko Muturangi

Ta Muturangi

Ko Hotuope

Ta Hotuope

Ko Hoturoa

(Te Whiwhi 1852: 44-45).

This long line of descent which traces fifteen generations of ancestry positions the manuscript firmly within a Tainui waka framework. The mention of Hoturoa is particularly important in this context because his name demarcates a crucial and literally landmark moment in our history when our people first came to Aotearoa from Hawaiki. This has the effect of linking the narratives given in the main body of the text which are implicitly understood to be set in Hawaiki, prior to our ancestors' 
arrival in these islands, directly to Aotearoa. This naming of Hoturoa marks the space between stories which happened prior to Maori arrival in this land. Maori waka identities remain highly significant today and are still invoked in both formal and informal korero and waiata. Importantly, for the purposes of this thesis, both Ngati Raukawa and Ngati Toarangatira trace descent from Hoturoa.

The whakapapa continues from Hoturoa to Hotumatapu to Motai, another important ancestor of many Tainui iwi including Ngati Raukawa and Ngati Toarangatira, who is immortalised in the saying 'Motai tangata rau'. ${ }^{123}$ From Motai the whakapapa continues to Ue, Raka, Kakati, Tawhao, and Turongo, another notable ancestor who travelled from the Waikato area to the Tai Rawhiti area of Te Ika a Maui where the beautiful Mahinaarangi beguiled him and with whom he eventually returned to the Waikato area. The names included in the whakapapa track not only across time over generations of ancestors but also across place: whereby Ranginui can be understood to exist in or signify the place of Hawaiki and Hoturoa marks a movement from Hawaiki to Aotearoa, the naming of Turongo recalls a sense of movement and mobility within Aotearoa specifically between the areas of Waikato and Te Tai Rawhiti, between the west and east coasts of the middle of Te Ika a Maui. From Turongo the whakapapa arrives at Raukawa, the son of Mahinaarangi and Turongo from whom the iwi of Ngati Raukawa takes its name:

\author{
Ta Hoturoa \\ Ko Hotumatapu \\ Ta Hotumatapu \\ Ko Motai \\ Ta Motai \\ Ko Ue \\ Ta Ue \\ Ko Raka
}

\footnotetext{
123 'Mōtai's hundred progeny' (Mead and Grove 2001: 311). See also 'He iti nā Mōtai, he uri tamawahine, tēnā kei te rāwhiti e taka ana, māna e takahi te one i Hākerekere' ('One from Mōtai, a descendant of a daughter, now in the east, who will trample the sand of Hākerekere') (Mead and Grove 2001: 76). Motai is also the tekoteko on the wharenui at Raukawa marae in Otaki, the marae matua of Ngati Raukawa te au ki te tonga.
} 
Ta Raka

Ko Kakati

Ta Kakati

Ko Tawhao

Ta Tawhao

Ko Turongo

Ta Turongo

Ko Raukawa

(Te Whiwhi 1852: 44-45).

The whakapapa continues from Raukawa and follows down seven more ancestors to arrive at Parekohatu, Te Rauparaha's mother. Before Te Rauparaha is mentioned, however, the whakapapa traces a line that begins with Te Rauparaha's elder sister Waitohi. Following Waitohi, Te Rangihaeata and his sister Te Kuini Rangitopeora (referred to as 'Te Rangitopeora' in chapter five of this thesis) appear. It is at this juncture that the writer of the manuscript himself, Henare Matene Te Whiwhi, is entered in the whakapapa underneath his mother, Te Kuini Rangitopeora. One of Te Whiwhi's children, his son Wirihana Te Whiwhi, immediately follows:

Ta Raukawa

Ko Takihiku

Ta Takihiku

Ko Tamatehura

Ta Tamatehura

Ko Huitao

Ta Huitao

Ko Haehaeora

Ta Haehaeora

Ko Ngatokoaru

Ta Ngatokoaru

Ko Huia

Ta Huia

Ko Korouaputa 
Ta Korouaputa

Ko Parekohatu

Ta Parekohatu

Ko Waitohi

Ta Waitohi

Ko Te Rangihaeata

Muri iho i a Te Rangihaeata

Ko Te Kuini Topeora

Ta Te Kuini Topeora

Ko Henare Matene Te Whiwhi

Ta Henare Matene Te Whiwhi

Ko Te Wirihana Te Whiwhi

(Te Whiwhi 1852: 46-47).

The inclusion by the writer of himself cements his position within a RaukawaToarangatira, and more broadly Tainui, framework. Moreover, as Maori scholar Ranginui Walker notes, “The story-teller, by reciting his genealogy to the canoe ancestors and back to the Hawaiki homeland, can ultimately link himself to the legendary heroes and the gods" (1992: 170). Through including himself in the whakapapa Te Whiwhi makes overt his own position in relation to the narratives he writes in his manuscript. Additionally, the inclusion of Wirihana Te Whiwhi shows that Te Whiwhi has issue and therefore suggests that Te Whiwhi's genealogical line will continue into the future. ${ }^{124}$ In a previous project I have argued that "This aspect of continuation is central to whakapapa as a living, mutable, positioning framework concerned with relationships" (Loader 2008: 63). Te Whiwhi's decision to include his son in the whakapapa implies an ever-evolving continuation of RaukawaToarangatira and broader Tainui identities. The inclusion of Te Whiwhi's son in the whakapapa also has important implications in terms of place: whereas Waitohi, Te Rangihaeata and Te Rangitopeora were active participants in the Raukawa-

\footnotetext{
124 Prolific nineteenth-century writer Te Rangikaheke similarly includes himself, his son and his wife in his whakapapa given in his manuscript entitled Tupuna (GNZMMSS 44), George Grey Special Collections, Auckland Public Library.
} 
Toarangatira-Ati Awa migrations from the Waikato and Taranaki areas to the south, Wirihana Te Whiwhi was born in the south after the peoples of Raukawa, Toarangatira and Awa had established themselves in this area of Te Ika a Maui. After including his son in the whakapapa, Te Whiwhi returns to Waitohi and her brother Te Rauparaha, after whom he then names Te Rauparaha's son, Tamihana Te Rauparaha:

\author{
Muri iho i a Waitohi ko Te Rauparaha \\ Ta Te Rauparaha \\ Ko Tamihana Te Rauparaha \\ (Te Whiwhi 1852: 47).
}

Te Whiwhi follows the lines of descent in order from the elder sibling, Waitohi, to the younger and in this case the youngest sibling, Te Rauparaha. Te Whiwhi does not list the other three siblings of Waitohi and Te Rauparaha which is perhaps due to these relations being peripheral to the genealogical lines that Te Whiwhi must have wished to draw attention to here. Alongside the discussion above about Wirihana Te Whiwhi, it is notable that Te Rauparaha's line here ends with Tamihana Te Rauparaha who had no issue. Tamihana and his wife Ruta did adopt several children but none of these children are included in this whakapapa.

Te Whiwhi shows his own line of descent from many of the illustrious ancestors of wider Tainui waka, Waikato iwi and specifically Ngati RaukawaNgati Toarangatira pedigree including his grandmother Waitohi, his uncle Te Rangihaeata, and his mother Te Rangitopeora. Te Whiwhi also illustrates his close relationship to Te Rauparaha and his son, Tamihana Te Rauparaha. Te Whiwhi pauses in his whakapapa recitation here and adds, "Kaore he tangata i penei te toa me te Rauparaha no runga mai i ona kainga i Kawhia i Maungatautari no ona tupuna iho, te whakamutunga o tana mahi e takoto nei" (Te Whiwhi 1852: 47). This pause in the whakapapa reflects upon the importance of Te Rauparaha in terms of the striking chiefly and leadership qualities he exuded, his eminent ancestral lines, and his infamy within his own people who hailed from Kawhia and Maungatautari. 
A further subtextual reason for Te Whiwhi's comments in regards to Te Rauparaha can be drawn from Te Whiwhi's comments in regards to place. Te Whiwhi names Kawhia and Maungatautari, two places in the Waikato area synonymous with Ngati Toarangatira and Ngati Raukawa prior to the migrations south (and still today for the Ngati Raukawa hapu who continue to reside at Maungatautari). The second part of Te Whiwhi's comment, "te whakamutunga o tana mahi e takoto nei" (1852: 47) draws a line between these places and his descendents to Te Whiwhi's contemporary generation and thus to the areas which Te Rauparaha's people occupied

in

Te Whiwhi's era. Te Whiwhi highlights Te Rauparaha as a pivotal ancestor which dually highlights Ngati Toarangatira and Ngati Raukawa's claims to land in the south. Te Whiwhi does not pause anywhere else in this whakapapa to relate any additional information or observations about the tupuna named.

After his brief but revealing pause with Te Rauparaha, Te Whiwhi continues the whakapapa, starting on a different line which traces Ngati Toarangatira descent from Hoturoa through to Toarangatira, the eponymous ancestor of Ngati Toarangatira. Te Whiwhi is explicit about tracing this specifically Ngati Toarangatira line writing, "Ka timata ki taua tupuna ano Ka rere kia Ngati Toa" (Te Whiwhi 1852: 48). The whakapapa begins again with Hoturoa who, as mentioned above, is the primary ancestor of the Tainui canoe from whom all Tainui iwi trace descent. Common Raukawa-Toarangatira descent is then traced from Hoturoa to Hotumatapu, Motai, Ue and Raka at which point the Raukawa and Toarangatira lines diverge:

Ko Hoturoa

Ta Hoturoa

Ko Hotumatapu

Ta Hotumatapu

Ko Motai

Ta Motai

Ko Ue 
Ta Ue

Ko Raka

Ta Raka

Ko Tuhianga

Ta Tuhianga

Ko Poutama

Ta Poutama

Ko Mango

Ta Mango

Ko Kaihamu

Ta Kaihamu

Ko Te Urutira

Ta Te Urutira

Ko Tupahau

Korokino

Ta Tupahau

Ko Toarangatira

(Te Whiwhi 1852: 48-49).

Toarangatira is followed by Marangai, Kimihia and Werawera, the father of Waitohi and Te Rauparaha. Te Whiwhi then writes that Werawera married Parekohatu and that Waitohi was born of this union. Waitohi is followed by Te Rangihaeata. The whakapapa then moves back to Waitohi and indicates that Te Rauparaha was born after her (in their generation). Te Rauparaha is again followed by his son Tamihana Te Rauparaha.

Ta Toarangatira

Ko Marangai

Ta Marangai

Ko Kimihia

Ta Kimihia

Ko Werawera

Ka moe i a Parekohatu, ka puta 
ki waho ko Waitohi

Ta Waitohi

Ko Te Rangihaeata

Muri iho i a Waitohi ko Te Rauparaha

Ta Te Rauparaha

Ko Tamihana Te Rauparaha

(Te Whiwhi 1852: 49).

Although Te Whiwhi does not include his mother nor himself after Te Rangihaeata, it is clear from reading the whakapapa from the beginning that Te Whiwhi and his mother fit into the whakapapa here. The fact that Te Whiwhi does not overtly include himself or his mother does not necessarily exclude them from this line of whakapapa. Reading quite literally between the lines their presence is understood albeit somewhat covertly. Understanding the ways that whakapapa such as the example here work conceptually is key to understanding the often intricate webs of relationships that they illustrate.

At this point in the whakapapa Te Whiwhi begins again with Marangai, a Ngati Toarangatira ancestor who appears in the specifically Ngati Toarangatira section of the whakapapa. The whakapapa lists a line of ancestors from Marangai, through Te Maunu, Te Mahuta, Takamaiterangi, Te Matoe and Rawiri Puaha to finally end with Hori Kerei Rawiri:

Ka hoki ano ki a Marangai

Ko te kawei tenei kia Ngati Toa

Ta Marangai

Ko Te Maunu

Ta Te Maunu

Ko Te Mahuta

Ta Te Mahuta

Ko Takamaiterangi

Ta Takamaiterangi

Ko Te Matoe

Ta Te Matoe 
Ko Rawiri Puaha

Ta Rawiri

Ko Hori Kerei Rawiri

Ka mutu tenei ka noi

(Te Whiwhi 1852: 49-50).

Rawiri Puaha was a close relative of Tamihana Te Rauparaha and Matene Te Whiwhi who was also a prominent contemporary rangatira. Puaha was the son of Hinekoto, a half sister of Te Rauparaha through his father Werawera and Matoe (Mitchell 2004: 106). Rawiri Puaha converted to Christianity and is remembered as one of the "younger" generation of Ngati Toarangatira after Te Rauparaha and his ilk (Mitchell 2004: 351). At the time of Te Rauparaha's unlawful detainment by George Grey, it was Rawiri Puaha, Matene Te Whiwhi and Tamihana Te Rauparaha who signed the deed authorising the sale of Wairau and Kaparatehau to the Government on behalf of Ngati Toarangatira (Mitchell 2004: 351). The sale of this land was a condition of Te Rauparaha's release and was thus conducted while Ngati Toarangatira were held under duress by Governor Grey. ${ }^{125}$

Just as Te Whiwhi's son appears in the whakapapa immediately following Te Whiwhi, Rawiri Puaha's son, Hori Kerei Rawiri, appears in the whakapapa immediately beneath his father. This again underlines the importance of the continuation of genealogical lines and therefore the importance of having issue or children through which genealogies are carried into the future. "Hori" and "Kerei" are the Maori language transliterations of "George" and "Grey" respectively. ${ }^{126}$ It is notable that Rawiri Puaha's son may have been named after governor George Grey who illegally detained Te Rauparaha and forced the "sale" of vast tracts of Ngati Raukawa and Ngati Toarangatira lands.

The whakapapa at the end of Te Whiwhi's manuscript serves multiple functions and illustrates a rich tapestry of intersecting relationships. Te Whiwhi

\footnotetext{
125 See Burns (1980: 284).

126 Rawiri Puaha's son may have taken these names upon Christian baptism or he may have been named after George Grey as a sign of respect and honour. He may equally have been named after George Grey in order to memorialise the profound and often deeply negative effects that Grey's actions meant for Rawiri Puaha's people.
} 
draws three lines of whakapapa that share a common link through Hoturoa and the Tainui canoe and which also follow specifically Raukawa-Toarangatira lines of descent. These whakapapa lines culminate in the relationships between Matene Te Whiwhi, Tamihana Te Rauparaha and Rawiri Puaha.

Through the lives of the tupuna named in the whakapapa the manuscript is located not only in a specific frame of time but also within a geographic space. This space is connected to the tupuna who appear in the whakapapa throughout the generations and references back to places of significance in Raukawa-Toarangatira history. The whakapapa recalls places of significance in Raukawa-Toarangatira history through association of the tupuna named with their deeds and exploits. Hoturoa, for example, is remembered as the commander of the Tainui canoe and thus for his leadership in the journey from Hawaiki to Aotearoa. This long, ocean-going journey led to the eventual settlement of people from the Tainui waka in the Waikato area and particularly around Kawhia harbour where Tainui was ultimately interred at Te Ahurei (Taonui 2009a. Electronic source).

Some seventeen generations after Hoturoa, Te Rauparaha is named in the whakapapa. Te Rauparaha was responsible for instigating and leading the migratory journeys that Ngati Toarangatira and some hapu of Ngati Raukawa and Te Ati Awa made from the Waikato and Taranaki areas in the early nineteenth-century to the southern parts of Te Ika a Maui. Te Rauparaha thus bridges a time between when our Raukawa-Toarangatira ancestors lived in the Waikato area to when they resettled in the Kapiti-Horowhenua and Tau Ihu areas. ${ }^{127}$ This movement in location was a large-scale venture which spanned the course of several years. The settlement of Ngati Toarangatira, Ngati Raukawa and Te Ati Awa in the Kapiti-HorowhenuaTau Ihu area was marked by Te Rauparaha and his allies' decisive wins in battle against the tangata whenua of this area at the time and ultimately resulted in the subjugation of these people by Te Rauparaha and his allies.

\footnotetext{
127 See Mitchell (2004: 101-111) for a comprehensive account of the migrations south. See also Burns (1980: 86-102). Ballara provides perhaps the most detailed account of both the events in Kawhia which led to the migrations and the events as they played out in the south in her two chapters 'Kāwhia' and 'Kapiti' (2003: 278-314; 315-354).
} 
Although Te Rauparaha's life marks a huge changing point in the geographic location of all of Ngati Toarangatira and many Raukawa tupuna, it is the confluence of all the ancestors listed in the whakapapa and all the specific places associated with them that locates the manuscript within the geographic landscape of RaukawaToarangatira traditions. Viewing the places associated with individual ancestors combined together as parts of one greater narrative reveals another space in which Raukawa-Toarangatira histories are located. Hoturoa and Te Rauparaha are examples of two particular tupuna who stand out in regard to the geographic positioning of Raukawa-Toarangatira people at specific junctures in our traditions and histories but they are by no means the only ancestors named in the whakapapa in Te Whiwhi's manuscript who do this.

The whakapapa included at the end of the manuscript thus serves the important function of contextualising the manuscript in both spatial and temporal ways. Rather than marking space and time through the use of calendar dates or the mention of place names except where Te Whiwhi pauses on his first mention of Te Rauparaha, the whakapapa can be read through close examination of the tupuna named. Incorporating wider knowledge about who these tupuna were and what they did enables a reading of the whakapapa which spirals outwards to include many more histories of the tupuna who are named within it. Reading the whakapapa which appears at the end of the manuscript clearly positions the manuscript in a distinctly Raukawa-Toarangatira paradigm. The three strands of whakapapa given link directly to Hoturoa and the Tainui waka and thence to the eponymous ancestors of Ngati Raukawa and Ngati Toarangatira.

\section{Conclusion}

Close reading of the whakapapa lists which Te Whiwhi includes at the beginning and end of his manuscript, the whakapapa lists which appear throughout the manuscript and the whakapapa which appears in a narrative form within the context of the larger narrative of the manuscript reveal whakapapa working on a 
number of levels and serving a number of functions. The whakapapa connect the manuscript, the narratives and the tupuna named to the atua as well as to each other in complex yet specific ways. The whakapapa also tell stories of their own which are often reached only through reading the subtext contained in each whakapapa. Through reading the whakapapa of this manuscript the specificities of people and place are made overt which in turn centre the narratives in tribal space. Through reading the whakapapa and reading for whakapapa connections and relationships which enhance the narratives are articulated. 


\section{POU TUATORU: SECTION THREE}

\section{Chapter Five: Reading tribalscape in two tangi composed by Rakapa Kahoki}

\section{He Korero}

Tupuna tane feature prominently in my whanau history. My great grandfather, Kingi Tahiwi, and one of his brothers, Pirimi Tahiwi, for example, are both profiled in the Dictionary of New Zealand Biography. Potted histories and photographs of these special tupuna are available to me at a click of a button and via other print sources. Locating information and literature about my tupuna wahine is, however, much more challenging. Where can I find out about the mothers, partners and daughters of the tupuna mentioned above? How am I to find out about who these women were, the things that they did and how they lived their lives? The stories of the tupuna wahine in my whanau are often remembered and spoken about as are the stories about our tupuna tane. But the stories of our tupuna wahine do not appear nearly so readily in the written literature.

A small narrative is written in cursive blue ink on the pages of my koro's whakapapa book. The details are specific, concise, sparing. One of my uncles recorded that my koro and his whangai father who worked the family farm at Omaio would return to the farm house for their main meal each day. My koro's mother prepared this meal for them. One day my Koro turned to look at the farm house from the hills above and he noticed that no smoke was coming from the farm house chimney. This is how he knew that his mother was dead.

This small story could be about my koro and the tragic circumstances surrounding his mother's death, but it could equally be about my koro's mother and her life. The story tells us, amongst other things, that Kahurangi Arapeta worked hard to provide food and sustenance for her whanau. It tells us that she alone was responsible for feeding my koro and his papa. Remembering our kuia relies not only on the stories we choose to recall and share but on how we tell and interpret those stories. 


\section{Introduction}

Following on from Tamihana Te Rauparaha and Matene Te Whiwhi, I now turn my attention toward the third and final poupou in the whare whakairo, this thesis, Rakapa Kahoki. Kahoki was a sister to Matene Te Whiwhi through their mother Te Rangitopeora. ${ }^{128}$ Kahoki was also a prolific composer of waiata. A respected leader of her people, George French Angas described Kahoki as, "a woman of strong mind, with a proud and queenly bearing" who "by her powerful talents, combined with her high birth" possessed "an almost unlimited influence amongst her people" (cited in Burns 1980: 183). In order to foreground Kahoki's talents in the area of waiata composition it is pertinent to look to other members of her whanau who are also well-known for their waiata composition. This whakapapa of compositional skills foregrounds the skills and talents, the pumanawa or whanau tradition, of excellence in composition which Kahoki in her time inherited. As Pateriki Te Rei says of Kahoki, her mother Te Rangitopeora and her grandmother Waitohi:

Ko ēnei kuia katoa, he wāhine tū marae, he wāhine whai mana. E kōrerotia tonutia ana ngā kōrero mō ēnei kuia ki runga i ngā marae, i ngā hui o Ngati Raukawa me Ngati Toa tae noa ki ēnei rā (Royal 1994: 66).

All of these women were greatly influential and participated in all major issues that affected their people. They spoke widely on matters that concerned Ngati Raukawa and Ngati Toa, often speaking on marae themselves, and their deeds are well remembered in tribal councils today (Royal 1994: 65-66).

Fleshing out this whakapapa enables me to gesture towards other poupou who belong in the larger whare whakairo of Raukawa-Toarangatira intellectual traditions. It also helps sketch out the broad contours of a much longer view of the intellectual traditions to which the works studied in this thesis belong.

In addition to being a leader of her people and a powerful landowner, Kahoki's mother, Te Rangitopeora, was a prolific composer of waiata

${ }_{128}$ Matene Te Whiwhi's father was Te Rangikapiki of Te Arawa and Kahoki's father was Te Wehi-o-te-Rangi, another rangatira of Te Arawa (Sparks and Oliver 1990a: 546). 
(Mikaere 1994: 129). Te Rangitopeora is well-remembered for the poetic excellence and strength of her composition and she made her mark as a composer as a very young woman prior to the southward migrations in the early nineteenth-century. Sparks and Oliver write:

In the course of the wars between Ngati Toa and other Waikato tribes, Ngati Pou killed a number of Ngati Toa women, including Topeora's sisters. She composed a cursing song, predicting violent and degrading deaths for the chiefs of Ngati Pou. Her uncle, Te Rauparaha, fulfilled the prophecy, killing and eating those named in the curse (1990a: 546).

Te Rangitopeora is remembered in connection with the killing of those named in her curse and for the waiata that she composed on this occasion. ${ }^{129}$ Te Rangitopeora also composed a kaioraora in response to Te Ati Awa's neutral stance after George Grey had Te Rauparaha arrested and held without charge. ${ }^{130}$ Te Rangitopeora was venerated by her people as an ariki tapairu, a queen-like woman (Macdonald et.al 1991: 685). She was said to have been proud, domineering, and beautiful and to have had a number of intimate relationships (Macdonald et.al 1991: 685). 131 Te Rangitopeora was one of thirteen women known to sign the Treaty of Waitangi (Mikaere 1994: 132). ${ }^{132}$ When she was baptised at Otaki on 2 May 1847, she took the name Te Kuini Wikitoria (Queen Victoria) and one of her husbands was given the name Arapeta (Albert) after Queen Victoria's consort (Sparks and Oliver 1990a: 547).

Kahoki's waiata whakapapa is not limited to this direct, vertical connection to her mother. Other female relatives besides her mother were highly renowned for

\footnotetext{
129 This waiata was first published in Grey (1853: 300) and Percy Smith quoted it in his account of the battles of Te Rauparaha. Percy Smith's account was published in The Journal of the Polynesian Society (18(51)). For the full text of this waiata see Ngata and Jones (2006: 502-503). 130 See Grey (1853: 282) for the text of this waiata.

131 See also the famous Lindauer painting of her reproduced in black and white in (Cowan 1930a: 167). 132 Mikaere notes that there may have been many more women who signed the Treaty but because Maori names, like the language, are generally gender-neutral it is difficult to tell how may more women were involved (1994: 132).
} 
their skills in composition. For example, three waiata aroha composed by Topeora, 133 a daughter of Te Rangihaeata (niece of Te Rangitopeora and cousin of Rakapa Kahoki and Matene Te Whiwhi), appear in Ngata's Nga Moteatea. ${ }^{134}$ Topeora II is said to have been a prolific composer whose waiata "have a vogue throughout the land" (Ngata 1972: 155) ("He wahine tau-titotito a Topeora; he maha ana waiata i tito ai, kei ona iwi, a kei te motu e waiatatia ana" (Ngata 1972: 154)). Kahoki's compositional whakapapa thus extends to her cousin, Topeora II. Kahoki's compositional whakapapa also includes such notable male rangatira as Te Rauparaha ${ }^{135}$ and Te Rangihaeata. ${ }^{136}$ Kahoki and her close relatives belonged to the rangatira classes of Raukawa-Toarangatira and excelled at such arts as was expected. Many members of this kawai rangatira showed themselves to be expert composers of waiata in addition to their oratory and other fine arts, warfare, political, social and leadership skills.

Notwithstanding her distinguished whakapapa and prominence amongst her own people and her people's histories and traditions, little about Kahoki appears on the written historical record. ${ }^{137}$ We know that Kahoki was, like her mother and grandmother, an important leader of her people who, took an active role in politics and the welfare of her people often alongside her brother Matene Te Whiwhi. She was also a passionate woman whose love affairs were legendary. Although she had no children of her own, she raised several whangai children. According to evidence

\footnotetext{
133 A note in Ngata and Jones' Nga Moteatea advises that Kahoki's mother, Te Rangitopeora, was known as Topeora 'the great' ('Topeora nui') and that Te Rangihaeata's daughter, Topeora was the second Topeora ('Tērā anō te Tope-ora tuarua, he tamāhine nā Te Rangihaeata') (2006: 500-501). 134 See Ngata (1972: 154-155; 156-157; and 234-235).

135 See 'Tērā ia Ngā Tai o Honipaka' (Royal 1994: 48-51), 'Kīkiki, kākaka' (Royal 1994: 82-85) and ‘He Hokioi' (See Royal 1994: 86-87). Tracing the history of Ngati Toarangatira and Ngati Raukawa through waiata would be a fascinating exercise. Royal gives a condensed version of the broad shape that this work might take in the section on the Raukawa-Toarangatira migrations to the south in his introduction to Käti Au I Konei (1994: 16-27).

136 See for example 'Taku waka whakairo' in Royal (1994: 102-106).

137 One area in which her activities are publically recorded is in the Maori Land Court. Kahoki appears in the court minutes on 31 March 1868, 20 April 1868, 12 February 1869, 28 June 1870 and again on 1 July 1870 as a claimant and counter claimant at hearings in the Otaki area.
} 
given by her brother Matene Te Whiwhi in the Maori Land Court, Rakapa Kahoki died in $1876 .{ }^{138}$

Two waiata texts appear in the front of the manuscript written by Tamihana Te Rauparaha about the life of his father, Te Rauparaha. ${ }^{139}$ These waiata are written on two sides of a single piece of manuscript paper which has been bound with the much larger manuscript. The piece of paper upon which the waiata texts are written is noticeably smaller than the rest of the pages of the manuscript. According to McRae and Jacob, the transcription of waiata in written forms was not uncommon at the time:

I te rautau 19, ka tahuri te Maori he ara hou hei pupuri kōrero, i tua atu i te maumahara noa. Koia tērā ko te tā i ngā waiata ki te pepa. Ka tuhia mā ngā Pakeha ngākaunui mai ki ēnei tū kōrero, pērā i a Grey, ka tuhia anō ki te pukapuka mā rātou ake, ka tuhia ki ngā reta whakawhitiwhiti ki ngā hoa, me ngā reta ki ngā nūpepa Maori. I te takanga o te wā, ka rerekē haere anō ngā kupu o roto i ngā waiata, te hanga, te puoro, me ngā take i titoa ai (McRae and Jacob 2011: 80).

In a new addition to their oral practice of memorising, Maori in the $19^{\text {th }}$ century set about recording their songs on paper. They wrote them down for interested Pakeha such as Grey and in manuscript books of their own, and quoted them in letters to one another and to the Maori-language newspapers. And they gradually made changes to the content, form, music and purpose (McRae and Jacob 2011: 81).

Both the waiata and the larger manuscript are written in Tamihana Te Rauparaha's hand and are catalogued as GNZMMSS 27 in the Sir George Grey Special Collections section of Auckland Public Library. A line introducing the first waiata reads, "Te tangi a Rakapa Kahoki mo Tona Waea mo te Kuini" (Te Rauparaha 18?: unpaginated). A line introducing the second waiata reads, "Tangi Tuarua tenei mo te Kuini Topeora na Tana Kotiro" (Te Rauparaha 18?: unpaginated). For reasons

\footnotetext{
138 Otaki Maori Land Court Minute book, 30 October 1879: 69-70. During this hearing, Kahoki's brother Matene Te Whiwhi applied to the Court to succeed to Kahoki's interests in the land block known as Mangahanene no. 1. In his statement to the court, Matene Te Whiwhi tells the court that Kahoki died 'about three years ago'.

139 This manuscript forms the basis of section one of this thesis.
} 
we can only guess, Tamihana Te Rauparaha wrote the words of two waiata tangi that his cousin Rakapa Kahoki composed for her mother Te Rangitopeora. There is no evidence to suggest that Kahoki herself ever wrote down the words of her waiata. 


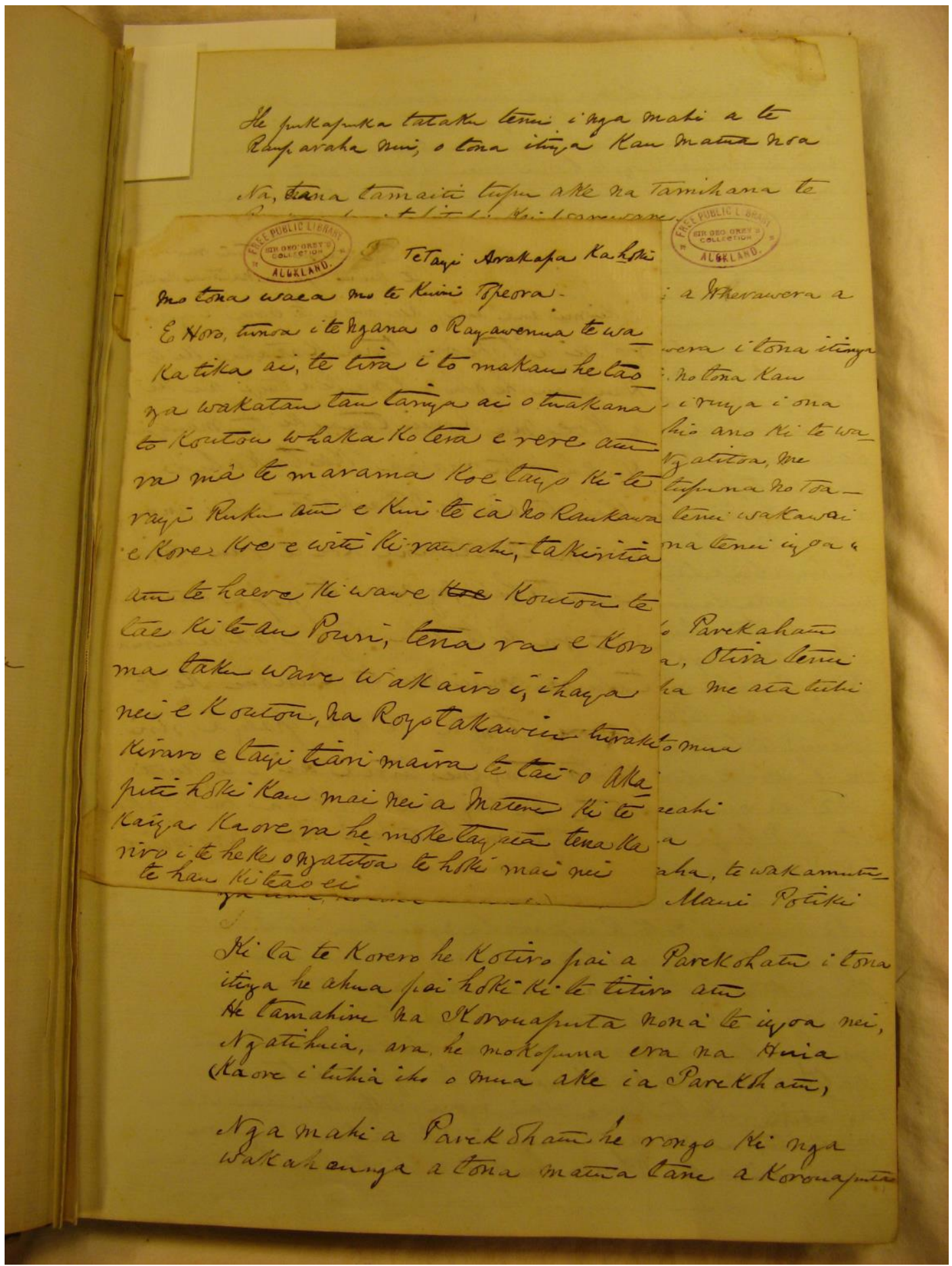

PHOTOGRAPH 2: RAKAPA KAHOKI'S FIRST TANGI FOR TE RANGITOPEORA AS IT APPEARS IN TAMIHANA TE RAUPARAHA'S MANUSCRIPT. 


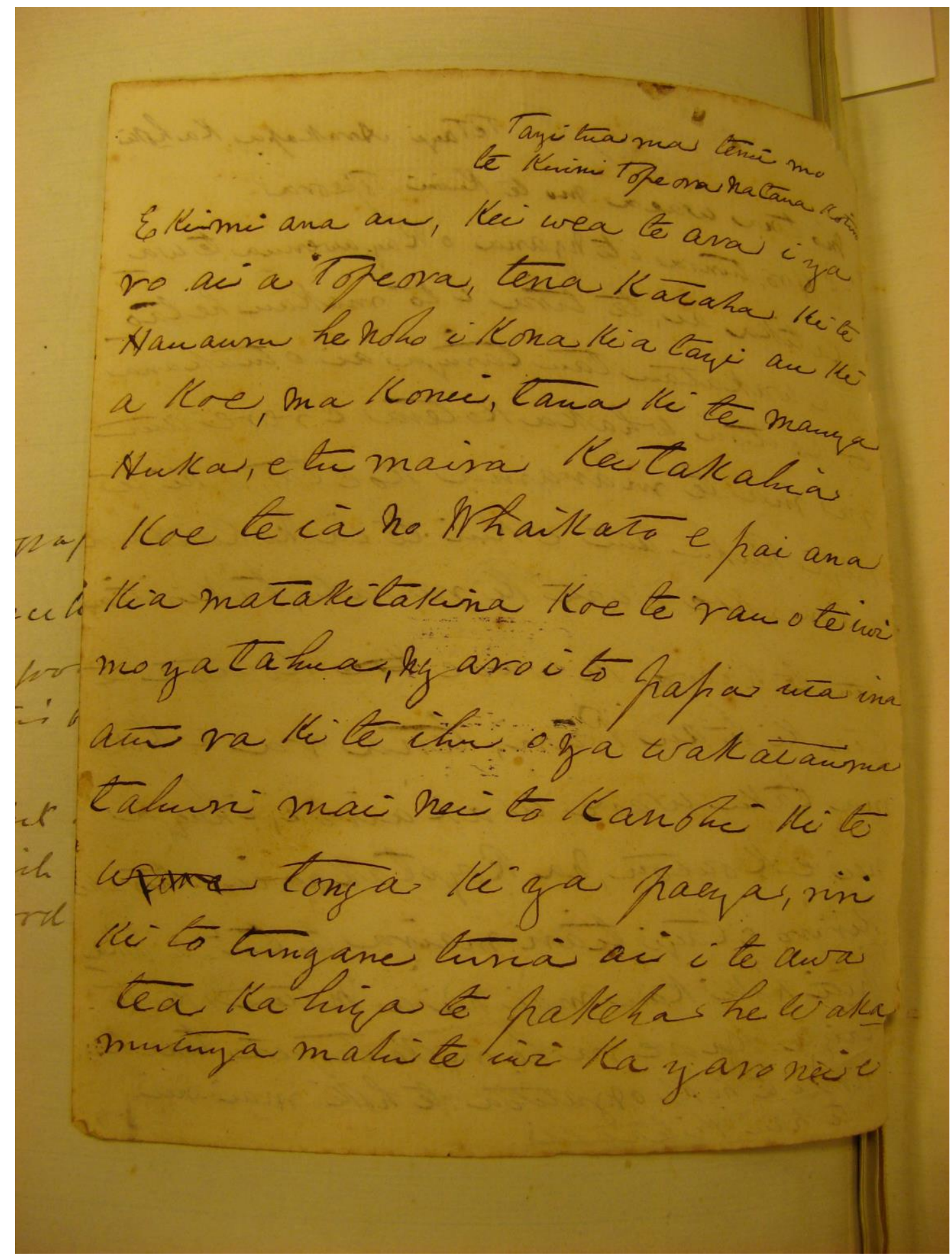

PHOTOGRAPH 3: RAKAPA KAHOKI'S SECOND TANGI FOR TE RANGITOPEORA AS IT APPEARS IN TAMIHANA TE RAUPARAHA'S MANUSCRIPT. 
While Tamihana Te Rauparaha's manuscript about the life of his father has been used by a number of other writers to produce their own works about Te Rauparaha's life and deeds (see chapter one of this thesis), none of them have commented on these waiata texts. While the writers constructed their own histories, variously translating and interpreting Tamihana's narrative or otherwise mining Tamihana's text for information on Te Rauparaha, these tangi, although in plain view, have been ignored.

It is useful at this junction to draw on the discussion of a specific short story in the book The Purloined Poe. Although a full discussion of this theoretical angle lies outside the scope of this thesis, it is, however, worth drawing attention to Lacan's argument: 'a letter always arrives at its destination' (Muller et al 1988:53). Critical discussions in the book argue that letters exist in a tri- rather than bi-configuration in which there is the author, the intended recipient, and some other party who intercepts the letter for their own reasons. This perspective on reading correspondence intended for someone else is pertinent in a consideration of how to read waiata which were composed by Rakapa Kahoki, written down by Tamihana Te Rauparaha and collected by George Grey. To return to Kahoki's waiata, we are reminded that Kahoki composed these two tangi for her mother, Te Rangitopeora, and that Tamihana, for whatever reason, transcribed them for George Grey. Grey, in turn, added the words to his collection of Maori manuscript material and at some point had these words bound with a much larger, 100-plus page, complete manuscript about the life of Te Rauparaha.

Although this Purloined Poe discussion foregrounds how to read correspondence, some clear implications are applicable to reading waiata in the archives. What does it mean when waiata are recorded in writing so far beyond the bounds of their original, oral context? There is no way that Kahoki could have predicted the track her tangi would take once they had been written down: Who would come upon her words in the future? What new audience would they find? How would they be interpreted? In studying her tangi texts, a researcher such as 
myself contributes to a growing chain of interested "third party" members who have intercepted the waiata between the composer and their intended audience.

In order to develop a methodology for reading waiata in the context of this thesis, I have considered key strands of reading practice developed in the work of such scholars as Apirana Ngata (1928; 1961; 1972), Pei Te Hurinui Jones (1961), Hirini Mead (1969), Margaret Orbell (1978; 1991), Charles Te Ahukaramu Royal (1994), Christine Tremewan (2002) and Jane McRae and Heni Jacob (2011). Certainly, these readings are limited in certain ways by their being textual analyses which cannot account for the effect that the tune or air has on the overall composition. ${ }^{140}$ As Charles Royal observes:

Waiata is purpose-built music. It was never sung in isolation, but was written and performed to engender reactions, make connections, revive memories in listeners, composers and performers alike. Waiata reflect the dynamics present between groups of people who are linked by genealogy and historical incident. The personality and meaning of waiata is intimately rooted in the personalities of composer, performer and listener. The totality of the experience gives rise to the music, to the art (Cited in Kerr 1994: 325-326).

The close readings which follow are textual analyses which examine the words of the tangi as text. It is important to acknowledge this at the outset and yet I argue that this need not be understood as a limitation but rather as a particular way of reading the waiata. The close readings which follow concentrate on the poetic features of the tangi and the possible meanings these might have in isolation from the musical form, the oral performance which represents an important part of what Royal refers to as "the totality of the experience" (Cited in Kerr 1994: 326). Tremewan notes that in the nineteenth-century:

Maori continued to compose all the traditional forms of poetry with vocabulary, images and concepts drawn from the past, and they used it in traditional ways, to

\footnotetext{
140 As distinguished Maori scholar Apirana Ngata notes, 'E kore e oti pai te mahi i nga waiata Maori ki te kore nga rangi e hopukia kia mau' (1972: x); 'There can be no proper rendering of Maori songs without capturing the air' (1972: xvii).
} 
celebrate their dead, give voice to their sorrows and grievances and add subtlety and beauty to their speeches. But they also adapted their songs in response to changing conditions: new concepts were expressed in new vocabulary, and songs were used to make forceful statements to the new political rulers. Poetry became a written as well as an oral form (2002: 129).

Tremewan draws attention to the changing conditions which saw waiata being written down for the first time. It was these changing conditions which not only enable me to do the work of conducting close readings on the text, but also preserved the words of many of these early waiata. Tremewan's use of the word "poetry" for "waiata" also highlights the more strictly literary work which I undertake here in my readings of Kahoki's waiata texts and aligns my work with that of other literary theorists, language experts and historians who have conducted similar work on early Maori waiata texts. ${ }^{141}$ The act of writing brings waiata into a new context, different from its original oral context, but equally as meaningful. As Hirini Melbourne so eloquently writes:

It is time to cease being defensive about Māori language and culture, seeking to preserve what remains. The task now is to set about reconstituting the links between the three essential elements of that culture: the context (whare whakairo), the orators or writers, and the audience (my emphasis) (1991: 139).

Melbourne includes both oral and written forms of literature within the wider context of Maori intellectual traditions. The close readings which follow take up the written forms of Kahoki's waiata and aim to reconnect my reading audience with the waiata texts within the context of this thesis.

Secondly, it is important to note that the composition of waiata is a genre in which Maori women figure particularly highly. Ngata observed:

\footnotetext{
${ }^{141}$ Smith notes that, 'Pākehā distinguish songs from poetry. However, Māori make no such distinction. For Māori, waiata were part of their daily lives, the medium for expressing feelings and for the retention and transmission of culture' (2001: 103).
} 
Ahakoa i a Tainui, ahakoa i a Te Arawa, i a Matatua, i a Horouta, i a Takitimu, i a Aotea ka whakaputa he wahine nana i tito nga tangi, nga waiata aroha, nga patere, nga kai-oraora, nga oriori (Ngata 1961: x).

Whether it be of the Tainui, Te Arawa, the Matatua, the Horouta, the Takitimu, or of the Aotea there would emerge an outstanding woman who composed laments, love songs, derisive songs or patere, songs of defiance and curses or kaioraora, and lullabies or oriori (Ngata 1961: xi).

Ngata draws attention to the prevalence of Maori women composers and highlights this as an aspect of Maori composition which extends beyond tribal and even waka descent bounds. ${ }^{142}$ Kahoki's compositional work can be seen to belong to a much broader tradition of Maori women's artistic expression. ${ }^{143}$ This is important because it draws attention to an intellectual and artistic tradition in which Maori women's voices can still be heard. Whereas Maori women's voices are frequently diminished, sidelined or missing from dominant historical narratives of Aotearoa New Zealand, waiata is a genre in which Maori women's voices live on. That women were not afforded the same opportunities in nineteenth-century Aotearoa New Zealand is underlined by the voice of Tamihana Te Rauparaha coming through loud and clear in his substantial manuscript records while the voice of his spouse, Ruta Te Rauparaha, is not only greatly reduced but heavily mediated. ${ }^{144}$ Waiata is one space, genre or area where nineteenth-century Maori women's voices are heard loud and clear. This is not to suggest that Maori women's voices are not mediated, indeed, Kahoki's waiata were themselves written down by her whanaunga

\footnotetext{
${ }^{142}$ In relation to women composers as repositories of iwi history and knowledge Mikaere notes, 'That women played an important role in the maintenance and transmittal of iwi history and knowledge is clear from the numbers of waiata tawhito that have been composed by women. Nga Moteatea is full of such waiata written by women, some of whom were clearly quite prolific composers. It seems entirely logical that those responsible for the physical survival and continuance of the iwi should also play a significant role in the survival of its history and therefore its identity' (1994: 128).

${ }^{143}$ Kerr writes, 'Women have always been well-represented among Maori composers, and in fact composition was one of the few areas where male and female roles overlapped in traditional Maori society. Royal [Charles] asserts that "waiata written by Maori women composers represent an enduring female historical tradition of sung poetry."' (1994: 327) (Kerr does not give a reference for Royal's comments but on the previous page cites a conversation with him in January 1991). 144 While Ruta Te Rauparaha wrote letters to George and Eliza Grey, Sutherland argues that Ruta is unlikely to have actually written them herself and rather used scribes (2007: 149-150).
} 
Tamihana Te Rauparaha, published by George Grey and published again by Apirana Ngata and later still by Margaret Orbell and Charles Royal. But there is something about the words of their waiata living on and living on in certain circumstances through being transmitted orally which sets them apart.

Finally, a note on genre. It is interesting to note that all of Kahoki's published waiata can be classed according to Ngata's groupings as waiata aroha (1961: xxxiv-xxxvii). ${ }^{145}$ In regards to waiata aroha Ngata writes:

Ma te tangata tonu e whakaaro, ko te aroha te kaupapa nui o tenei hanga o te ngakau tangata. $\mathrm{Na}$, he maha nga whakaputanga o te aroha. I roto i nga waiata nei ko te aroha o te wahine ki te tāne te kaupapa whanui, he wahine ranei $\mathrm{i}$ wehea $\mathrm{i}$ te tāne...he wahine ranei i mahue i tana tāne ka rere ki tetahi atu; he wahine ranei i mahue i te kainga, ka rere te tāne ki nga pakanga; he wahine punarua ranei; he puhi ranei i pa ki te hara. Kei tenei momo waiata te reo whakaaroha, ahakoa he reo māmā (Ngata 1961: xxxiv).

One, of course, will realise that love is universal and in the minds of all mankind. Love manifests itself in many ways. In these songs it is the love of a woman for a man which has the widest scope; or it may be that of a woman forcibly parted...or it may be that of a woman deserted by her husband because of his infatuation for another; or a woman left at home by her husband who has gone off to war; or a woman sharing a husband with a co-wife; or a virgin set apart who has transgressed. In these songs are expressions of great pathos, although the language used is simple (Ngata 1961: xxxvii).

Like her mother Te Rangitopeora, Kahoki is remembered for her passionate love affairs. "He Waiata Aroha Mo Taitimu", for example recounts Kahoki's desperate heartache at being separated from her lover Taitimu of Ngati Tuwharetoa:

E kui ma, e katahi hanga kino, e

Haramai ki au whakaiwikore ai (Ngata 1972: 262).

\footnotetext{
${ }^{145}$ McLean and Orbell group what they call the 'sung forms', oriori, waiata aroha and waiata tangi, together as opposed to 'recited forms'. They assert that these 'sung forms', 'explored emotive links between the composer and the person to whom the song was dedicated, while being directed outwards to an audience of family and social connections' (1990: 29).
} 
O mesdames all, this is indeed a grievous thing, $e$

Which has come upon me and made me comfortless and sad (Ngata 1972: 263). ${ }^{146}$

Kahoki's waiata aroha take the form of what Orbell terms "complaints", that is, waiata aroha that do not celebrate the happy and exciting phases of love but rather lament unrequited or lost love (1991a: 2). Part of the beauty of waiata aroha is in their inherent tragedy and bitter-sweet nature and therein lies their power and sense of timelessness. The sentiments conveyed in such waiata are heightened by the composer's use of imagery, metaphor and simile. In Kahoki's same waiata for Taitimu, for example, Kahoki likens herself to a particular rock found at Oruanga, a place at Rotorua:

Ko te toka tapu au ki Oruanga ra, e,

Uhia atu ai e te rehu tai-toko (Ngata 1972: 262).

I am like the sacred rock at Oruanga yonder,

Which oft is submerged beneath the waves (Ngata 1972: 263).

The image is complex and may refer to feelings of despair which are linked to the feeling of drowning beneath the ocean waves and perhaps also of feeling rejected and therefore lost from sight. ${ }^{147}$ Being left to the mercy of the ocean currents also plays into the general theme of distress and dejectedness that Kahoki portrays throughout the waiata. In the explanations which he provided, Te Taite Te Tomo notes that Oruranga is a place at Kawaha, Rotorua (Ngata 1972: 263). "Taitoko" is translated into English simply as “The waves" (Ngata 1972: 263) but these lines can alternatively be translated, "I am at Oruanga, overwhelmed by my thoughts of Taitoko". ${ }^{148}$ This reference to "Taitoko" can be understood as a play on words which combines the imagery of the ocean tides with the name of her lover 'Taitimu".

\footnotetext{
146 'Ko te waiata a Kahoki mo Taitimu' in Grey's Nga Moteatea (1853: 123) and interestingly translated in Ngata's Nga Moteatea as 'A Song of Grief for Taitimu' (my emphasis) (1972: 263).

147 Additionally, Orbell notes that the image of low water (taitimu) is associated in a general way with the loss of life, 'for it was believed that people died when the tide was on the ebb. As well, the low tide was seen as removing the obstacle which lies between this land and Hawaiki. The tide will ebb to Hawaiki, and the poet's enemies will die. Nothing will bar the way' (1985: 16).

148 I am indebted to Rawinia Higgins who pointed this out to me.
} 
Another common poetic image found in Maori literature is "Taitimu, taipari" which refers to the ebbing and flowing ocean tides. Kahoki thus evokes the name of her loved one within the context of the surging image of the ocean tides in her waiata. Continuing on with her ocean imagery, Kahoki imagines herself being thrown into the ocean from the rock:

Hei whiu i au ki waho ki te moana

Kei noho au i konei maniora noa ai, e (Ngata 1972: 262).

On whose crest I might be tossed out to sea,

Rather than that I should rave about here in vain (Ngata 1972: 263).

This image is unmistakably dire and hints at feelings of despair and even suicide which results in the ultimate separation of death. This moment emphasises the fine line between waiata aroha and waiata tangi.

Waiata aroha can indeed be likened to tangi in many ways. Both waiata aroha and tangi lament loss. As Orbell notes, tangi not only mourned the death of a loved one, but other loss such as that of land or crops, or illness (1991a: 2). There is a common theme of loss which resonates across both waiata aroha and tangi forms and this common theme can be seen as the glue which binds both forms inextricably the one to the other. Ngata also noted the similarities between these two forms:

Ko te momo nui tenei o nga waiata Maori katoa ko nga tangi, ahakoa he aha te putake of te tangi. O nga waiata e rua rau i taia ki nga wāhanga e rua o nga pukapuka nei kotahi rau e rua he waiata tangi; a, mehemea i tikina atu etahi o nga waiata aroha, o nga waiata whaiaipo, e tika noa atu ana kia kiia he tangi, tera e maha noa atu (my emphasis) (1961: xvi).

Among the songs of the Maori, laments are by far the most numerous, irrespective of the theme of the laments. In the 200 songs now published in these two volumes 102 are laments; and if to this number were added some of the love songs and songs for an absent lover, which could quite well be called laments, there would be a very large number indeed (my emphasis) (1961: xvii). 
It is possible that waiata aroha and tangi are flip sides of the same coin. As Ngata notes, both could in fact be called tangi (laments) and both are generally inspired by loss (1961: xvi; xvii). In regards to the similarity between waiata aroha and tangi, McRae and Jacob note:

E rua, e rua, he whakapuaki i te kare ā-roto o te tangata kotahi (engari nā roto i te waiata tangi, rori ana hei kare ā-roto nō te tini tāngata), he poto te reo, he hāngai, engari he auaha, he huatau, $\overline{\mathrm{a}}$, e $\overline{\mathrm{u}}$ ana ki te tauira whānui kua takoto mō ēnei tū waiata. Ka mutu, he waiata ēnei i titoa hei whakaea i tētahi pōuri nui, he waiata kia kawea e te tokomaha hei whakaahua, hei whakamauru i te kino, $\mathrm{i}$ te mamae, hei whakaara rānei i ngā kare ā-roto, i te ngākau atawhai o ētahi atu (2011: 53).

They are similar in being personal expressions of feeling (although they are inherently communal too), and in having terse, poetic language and conventional patterns. In addition, because they were composed as a response to unhappy or difficult circumstances, these songs are rhetorical. That is to say, they were sung publically as a way of describing or relieving feelings, and of appealing to the emotions or help of others (2011: 54).

Kahoki's waiata aroha are an appropriate conceptual springboard to move into the core focus of this chapter, her two tangi recorded by Tamihana Te Rauparaha. Kahoki's tangi also fall into a group of waiata which Ngata broadly defines as "tangi" (1961: xvi). Of these types of waiata Ngata writes:

...ko nga waiata tangi, he kaupapa tauriterite ano o ratau, ko te mamae ko te pouri ki whakananawe i te ngakau, ka tokona ake ki waho te koinga, te haku, te tangi, te aue. Ko ona tohu he haehae, he ripiripi, he karanga ki nga atua, he poroporoaki ki te hunga mate; muringa ra he kohukohu ki te tangata, ki te iwi ranei nāna i patu, a, ka karanga ki nga whanaunga toa ma ratau e ngaki te mate (Ngata 1961: xvi).

...with regard to laments, they also have a pattern of their own; the pain of sorrow agitates the mind, and this finds expression in intense longing, complaining words, mournful lamentation and cries of anguish. This is accompanied by the scourging and lacerating of one's flesh, the gods are called upon, and a farewell tribute is paid 
to the dead; following this comes the cursing of the men or people who did the killing, and then the call is made to warrior relatives to go forth and seek revenge (Ngata 1961: xvii). ${ }^{149}$

While Kahoki's unpublished tangi fall under this broad category, they can be further defined under a category which Ngata heads, "He tangi mo nga rangatira i mate tarāwhare" (1961: xxii), or, “Laments for chiefs who die a natural death” (1961: xxiii). As pertains to these types of tangi Ngata writes:

Kaore e oho rawa te mauri, kaore e ketua nga kino o mua, kaore he huarahi mo te kohukohu ki te hoariri. Engari ka titiro māriri ake te tangata tito waiata ki nga ahua maha o te tupapaku. Na reira i noho ai ki enei o nga tangi a te Maori nga kupu whakapaipai o tona rea; ka ata hurihurihia hoki te kupu, ka waniwania kia reka ki te taringa, kia tau, kia hangai ki te take o te apakura (1961: xxiv).

The emotions are not roused, nor are past wrongs given in detail. There is no recourse to cursing of the enemy; instead, the poet describes the character and personality of the dead. For this reason these laments of the Maori contain the finest expressions in his language. Each word is carefully chosen and is of a quality which is pleasing to the ear; the words must also be dignified in character, and in keeping with the themes of the lament (1961: xxv).

As Ngata points out, tangi composed for rangatira who die a natural death need not concern themselves with naming enemies nor inciting retribution. The composer was thus able to lament and farewell their loved one free from the pain and anger caused by other types of death such as death in battle or by murder.

The close readings which follow proceed from the notion that tribal identity is important to Maori people. They explore how Kahoki's texts can be viewed through a tribal lens and what this tribal lens enables. The broader themes of tino rangatiratanga, whenua, history and writing which underpin this thesis come into play and are explored through the following close readings of the tangi texts.

${ }^{149}$ Sam (Timoti) Karetu similarly notes that, 'It is in the acknowledgments to the dead and in laments composed for the dead that some of the most beautiful examples of the language are found' (1975: 43). 
Kahoki's first waiata tangi for her mother Te Rangitopeora employs a form of direct address which echoes a feature of Maori oratory. The waiata draws on imagery from the natural world which, when taken together, form the basis of what I term a "tribalscape" of Ngati Raukawa and Ngati Toarangatira. I follow the lead of Smith who notes that:

Some writers broaden the concept of landscape to include seascapes, waterscapes, sunscapes, ethnoscapes and other types of -scape as collective aspects of the environment. In such contexts the suffix -scape "posits the presence of a unifying principle which enables us to consider part of the countryside or sea as a unit". ${ }^{150} \mathrm{I}$ use 'naturescape' as a term which is all-inclusive of different -scapes of the natural world including those mentioned above as well as the sky-scape. The term 'naturescape' aligns with a Māori world-view which sees all such -scapes being furthermore connected to people (2001: 190).

Extending on Smith's term "naturescape" I use the term "tribalscape" to refer to the geographic and intellectual territories that Maori tribes associate themselves with and often define themselves by. In his short summary of the main features which distinguish tangi for chiefs who die natural death, "He tangi mo nga rangatira i mate tarāwhare" (1961: xxii), Ngata goes on to say "Tera atu kei nga waiata maha nga kupu pena, whakarangatira. Katahi ka whakahuahua ki nga tipuna, ki nga waka o te tupapaku” (1961: xxvi) ("There are several other expressions of high tribute. The ancestors are named and also the canoes (of the migration) of the deceased personage" (1961: xxvii)). ${ }^{151}$ Kahoki's tangi for Te Rangitopeora, like so many other waiata of this particular type of tangi, names several important ancestors, makes connections to living descendents, and makes reference to the landmarks, waterways

\footnotetext{
150 Peters (1948: 2), in Cosgrove (1998: 13).

151 There are always exceptions, additions or variations to such comments as these and it is important to note that Maori styles and forms are in a constant state of flux. In his poroporoaki to Kingi Koroki in 1966, for example, Pei Te Hurinui Jones, 'covers the canoes of most other iwi, as opposed to Tainui only' (Tau 2012: 21). In his poroporoaki Jones mentions Te Arawa, Mataatua, Horouta, Takitimu, Kurahaupo, Aotea, Tokomaru and of course, Tainui. Tau furthermore notes that, 'In a sense, just as the waka of our ancestors beached upon Te-Ika-a-Māui and Te-Waka-a-Māui, we also send our dead back to their ancestors upon canoes' (2012: 21).
} 
and other physical and even metaphysical identifiers which combine to form a specific tribal-scape. ${ }^{152}$

\section{Tangi tuatahi}

In Kahoki's first tangi for Te Rangitopeora both Raukawa and Toarangatira are named within the context of the tangi. In line six Kahoki instructs Te Rangitopeora to dive into the currents of Raukawa:

rangi Ruku atu e Kui te ia no Raukawa

Kahoki here directly addresses Te Rangitopeora with the words "e Kui". Kahoki thus employs a term which respects Te Rangitopeora's status as an older woman and pits herself in a junior position. The image of Te Rangitopeora diving into the currents of Raukawa furthermore orientates Te Rangitopeora around the specific geographic location of Raukawa moana. ${ }^{153}$ This small yet treacherous stretch of water was of huge import to the Raukawa-Toarangatira-Awa peoples who migrated to the Horowhenua-Kapiti-Te Tau Ihu areas in the early decades of the nineteenthcentury. These migrants from the Waikato and Taranaki areas eventually settled and took up strategic positions across the south-west of Te Ika a Maui and the northern parts of Te Waipounamu. These positions were consolidated by Ngati Toarangatira's capture of Kapiti island following the battle of Waiorua in 1824 (Tau 2009. Electronic source). ${ }^{154}$ Ngati Toarangatira and their allies positioned themselves

\footnotetext{
152 Copland notes that the words of poetry were as expressive of the environment as of the poet's own feelings and furthermore that regardless of theme, a song almost always named the places and invoked the physical environment of its subject (1975: 2358). Mitcalfe similarly observed that Maori poetic imagery was not so much classical, or historical, as natural (1961: 12) while Best notes that natural phenomena and landmarks often featured in the opening lines of songs (1924: 143) (Cited in Smith 2001: 103).

153 Also known as Te Moana-o-Raukawa and Rau-kawakawa (McKinnon 1997: Plate 25) and by its English name, Cook Strait or Cook's Strait.

154 Tau notes that this battle which occurred in 1824 at Waiorua on Kapiti Island, was the climax of a series of confrontations between Te Rauparaha and his people and the Muaupoko people (2009. Electronic source). McKinnon furthermore states that, 'a huge combined force of warriors drawn from as far north as Waitōtara and as far south as Arapāoa was defeated by a numerically smaller Ngāti Toa taua. Following Waiōrua, it was widely recognised that Ngāti Toa had conquered the land
} 
strategically around and on either side of Raukawa moana, the strait between Te Ika a Maui and Te Waipounamu, and effectively controlled the area. An important result of this control effectively secured a monopoly on trade between Te Ika a Maui and Te Waipounamu for Ngata Toarangatira and their allies. ${ }^{155}$ Associating Raukawa moana with Te Rangitopeora affirms Te Rangitopeora's mana as a chiefly woman of influence and power.

Raukawa moana was also a tapu waterway. In his manuscript about the life of his father (the subject of section one of this thesis) Tamihana Te Rauparaha relates the procedure that was followed which involved blindfolding the eyes of those who were crossing Raukawa for the first time with karaka leaves:

to Taranui, ko Raukawha te ingoa o taua moana, he moana tapu ki ona tangata, e kore e hoea noatia me kopare nga kanohi o nga tangata tau hou, katahi ano ka whiti i taua moana, me kopare ano te ihu o te whaka, he rau karaka nga kopare tuitui ai ka whakapiri ai ki te rae o nga tangata, kia ngaro rawha nga kanohi ko te kakau anake o te hoe e kitea iho me te whai me te rapa o te hoe, ko nga tau towhito anake e titiro ki nga tangata (Te Rauparaha 18?: 42).

Burns adds that, "After a safe crossing - safe only because none of those blindfolded had tried to see - the newcomers were carried ashore and their blindfolds laid on a tuahu or ceremonial place named Tuhinapo" (1980: 139). Although the distance between Te Ika a Maui and Te Waipounamu via Raukawa moana is not particularly lengthy, Raukawa moana is known to be an extremely treacherous stretch of water. That Kahoki instructs Te Rangitopeora to dive into the waters of Raukawa moana within the context of her tangi asserts the strength and power of Te Rangitopeora.

from Whangaehu in the north to Turaki-rae, a point to the east of Te Whanganui-a-Tara on the southern coast' (1997: Plate 29).

155 This is directly linked in to the first two reasons that Tamihana Te Rauparaha gives for Te Rauparaha's decision to migrate to south; 'Ko te Pakeha, ko te pounamu, ko te hua o te kai' (Te Rauparaha?: 11). 
In addition to this more literal interpretation of Kahoki's reference to Raukawa moana, the way in which the image is phrased suggests the ease with which Te Rangitopeora might now in her state of wairuatanga navigate the waves of Raukawa. Being free from the bounds of te ao kikokiko and her bodily form, Te Rangitopeora is at liberty to plunge into and dive through the rough and treacherous waves of Raukawa moana without restraint. This sense of being able to move freely through the territories of her people is heightened by the reference to a waterway which otherwise required much skill and care to successfully navigate.

The ocean imagery contained in the reference to Raukawa moana picks up on the image of a waka given several lines earlier:

ka tika ai, te tira i to makau he tao

nga whakatau tau taringa ai o tuakana

to koutou whaka ko tera e rere atu

ra ma te marama koe tango ki te

rangi Ruku atu e Kui te ia no Raukawa

This mention of a waka (ie "whaka") recalls a number of ways in which different types of waka are connected to Maori beliefs, customs and protocols around death. Often tupapaku would be transported in hollowed-out logs known as "waka tupapaku" to atamira, whare mate or to the mahau of the main wharenui for the duration of the tangihanga (Higgins and Meredith 2011. Electronic source). After the body had decomposed and the bones been scraped and cleaned, the koiwi were sometimes placed in "waka koiwi" or burial chests which would then be placed in caves or other secret locations in order to prevent them being desecrated by rival tribes. In addition to these physical waka there were also "waka wairua" or spiritual waka. Included amongst these what is referred to in oratory as "Te waka o Aitua" (Aitua being the personification of death) (Higgins and Meredith 2011. Electronic source). This waka is called Karamurauriki and has a bailer known as 
Tatataeore (Higgins and Meredith 2011. Electronic source). ${ }^{156}$ "Te waka o Tamarereti", named Uruao, is said to have distributed the stars in the sky and is also said to sometimes take wairua with it when it rises (Takirirangi Smith, 2012. Personal Communication).

The connection between the sky, waka and the oceans is also alluded to in the section of Kahoki's waiata quoted above where, immediately following her mention of a waka, Kahoki says that it is the moon who will convey Te Rangitopeora to the sky. ${ }^{157}$ This reference to the moon taking a woman from the earth is reminiscent of the narrative of Rona and the moon whereby the moon takes Rona to live with him after she curses him. This reference may allude to the similarities of circumstances that both Rona and Te Rangitopeora leave their earthly forms behind to take to the skies and become one with, or a part of, the firmament. This furthermore aligns with Maori beliefs that rangatira become stars upon their deaths and thus ascend to the skies as in the phrase "Kua wheturangitia".

This interweaving and complex imagery which links waka, the ocean and it's mirror image, the sky, is reiterated again in line nine where "te au pouri" or the dark or saddened tides are mentioned ${ }^{158}$ and again in line twelve where the tides of Kapiti are said to be crying or mourning. These references to the natural world furthermore tie in to the wider context of the Maori "nature-scape" within which Kahoki's tangi can also be situated.

A strong sense of the continuing journey that the wairua of the recently deceased takes before reaching their final resting place is also evident throughout Kahoki's waiata tangi. This is similarly expressed in poroporoaki with the deceased being implored to depart on their journey and to finally rest upon reaching their destination. Karetu gives an example, "Haere ki te kainga i tauiratia mai mo taua, mo te tangata. Haere ki Paerau, ki te huinga o te kahurangi. Ka oti atu ai $\mathrm{e}^{\prime \prime}$

\footnotetext{
156 Higgins and Meredith note that the white albatross feathers fastened to the bow-piece and also used to fashion streamers attached to the stern-piece of certain waka allude to Karamurauriki. Thus an important link between this waka wairua and te ao kikokiko is maintained (2011. Electronic source).

157 A further connection between the sky and sea is apparent in that way that our ancestors used the stars and other natural phenomena to navigate the open ocean (Taonui 2009c. Electronic source). 158 'Te au pouri' might also, as Rawinia Higgins pointed out to me, refer to the north.
} 
(1975: 43). Beliefs that wairua travel within Aotearoa to reach Te Reinga or, as it is also known, Te Rerenga Wairua in Te Tai Tokerau whereupon they are said to descend the roots of a pohutukawa tree and travel through the underworld to Hawaiki (Higgins and Meredith 2011. Electronic source), do not sit disparately from the idea of waka wairua or of celestial beings being integral in this journey. Karetu gives another example of a traditional way of farewelling the deceased, "Haere e hoki i runga i o koutou waka, ki Hawaiki-nui, ki Hawaiki-roa, ki Hawaiki-pamamao. Ki te Hono-i-wairua" (1975: 43). Like many if not all of the other peoples who occupy the numerous islands of Te Moananui-a-Kiwa, our people are travellers: Maori came from Hawaiki to occupy Aotearoa and ultimately return to Hawaiki upon death. ${ }^{159}$ The function of waka is fundamentally to convey people and possessions from one place to another whether this be over land or sea.

In a further addition to the reference to Raukawa being taken to refer quite literally to the stretch of ocean known as Raukawa moana, Kahoki's mention of Raukawa also calls to mind the tribe of Ngati Raukawa. Te Rangitopeora and Kahoki both affiliate to Ngati Raukawa with wider intersecting and interweaving whakapapa connections between concerning them and their whanaunga also coming in to play. In what appears to be a coincidence, the tribe of Raukawa share the same name as the stretch of ocean which came to be of such import to Ngati Raukawa, Ngati Toarangatira and Te Ati Awa following their migrations to the south. In her waiata Kahoki thus invokes both Raukawa moana and Raukawa

\footnotetext{
159 Hawaiki is the traditional and spiritual homeland of Maori people. It is where Maori ancestors came from and it is where Maori spirits return on their departure from this world. It is at once a physical location and a metaphorically spiritual location. This could be because, 'In the Māori view of the world, travels and migrations were seen both as physical movements and as spiritual journeys' (McKinnon 1997: Plate 17). The following is Royal's description of Hawaiki, 'The spiritual and philosophical foundations of Aotearoa based Māori culture were laid in the mysterious and mythical homeland called Hawaiki. Whereas Hawaiki must at one time have been an historical and physical reality, in 1000 years of settlement in Aotearoa, Māori mythologised Hawaiki as both the dwelling place of deities and divinities as well as the homeland to which all spirits return following the death of the body (1998: 102). Taonui furthermore notes that, 'Hawaiki was the most significant name transferred from Polynesia. In mythology it is the place from which all bounty came, including life, food and treasures. Ancestors referred to it as the source of life and destination of the dead - a paradise to which the spirits returned. The concept was so important that the name was given to many islands and places during migrations across the Pacific' (2009b. Electronic source). See also Royal (2012a. Electronic source).
} 
iwi in the one mention of Raukawa. In her one mention of Raukawa in her tangi, Kahoki invokes the geographic location of Raukawa moana and layers of other imagery associated with the moana, the waves and tides and also the people of Ngati Raukawa, Te Rangitopeora's people. ${ }^{160}$ The ocean imagery which is used to such poignant effect is recalled again at lines twelve and thirteen:

ki raro e tangi tiari maira te tai o Aka

piti hoki kau mai nei a Matene ki te

Here the tides of Kapiti are said to be weeping. This reference calls to mind another significant geographic, symbolic and spiritual presence on the tribal landscape. The looming stature of Kapiti island stands as an ever-present reminder of the mana that Ngati Toarangatira fought for and eventually won in this area. There is perhaps no greater sign of mana on the south-west coast of Te Ika a Maui than that which Kapiti represents. It stands sentinel off the coast with its western side buffeted by winds resulting in the sheer cliffs that are still seen today. In contrast, the eastern side rises in a relatively regular manner to Tuteremoana peak which stands very nearly in its middle. ${ }^{161}$ Its form is majestic, its position strategic and its symbolic power as a physical representation of the mana of the people absolute. Kapiti dominates this coast line. From its vantage points one can on a clear day make out nearby Mana island and much farther afield Te Waipounamu to the south and maunga Taranaki to the north. By naming Kapiti in her waiata Kahoki links Te Rangitopeora to one of the most dominant physical representations of the rights of her people within the Horowhenua, Kapiti and Tau Ihu areas. Linking Te Rangitopeora with this powerful

\footnotetext{
160 Mead similarly notes that in her waiata tangi for her son Ketekete Rangitukia, Hera Haawai identifies a prominent landmark by which her composition can be fixed to a definite locality (1969: 387) while Orbell notes that although the imagery employed in what she terms 'Maori poetry' is highly conventional, it is dually endlessly varied in matters of detail (1978: 7).

161 Smith notes, 'The most visible features in the landscape were high places, whether as headlands or promontories...or hills...which sometimes served as a resting place for the dead...More significant were the mountains' (2001: 208-209). Within the context of the southwest coast of Te Ika a Maui, however, Kapiti Island, along with its peak Tuteremoana, is the most visible single feature in the landscape. In comparison the Tararua mountain range stands to the east of Kapiti and is a collection of maunga which run like a spine along a north-south axis.
} 
symbol of tribal mana also clearly displays the mana with which Te Rangitopeora herself was held by her people.

Additionally, the significance of linking Kapiti to Te Rangitopeora is not limited to a symbolic or metaphoric notion. Te Rangitopeora signed the Treaty of Waitangi at Kapiti and she is also said to have allowed a whaler to use a piece of land on Kapiti against the wishes of her uncle Te Rauparaha and her brother Te Rangihaeata. ${ }^{162}$ Te Rangitopeora exercised considerable rights on Kapiti as was befitting of her rangatira status and was closely linked to the island and its management. Te Rangitopeora's death would have been felt throughout the territory of Ngati Raukawa and Ngati Toarangatira and further afield. This fact is supported not only by evidence of what Te Rangitopeora did and achieved in her lifetime but by the fact that, as has been noted by Pei Te Hurinui Jones, Maori would not have been bothered composing waiata for ordinary men and women (1961: 3). ${ }^{163}$ Te Rangitopeora was a woman of remarkable abilities and talents.

An important physical connection also exists between the currents of Raukawa moana and the tides of Kapiti. These areas are literally linked and can be conceptualised as one continuous ocean-way which reaches from the south-west coast of Te Ika a Maui through to Te Tau Ihu. This area broadly encapsulates the territory of Ngati Toarangatira, Ngati Raukawa and Te Ati Awa in the south. It is fitting that this territory should be outlined thus by the dominant landmark of this area, the island of Kapiti, and by the dominant waterway, Raukawa moana. This echoes how Maori to this day introduce themselves using tribal pepeha as defined by the prominent landmarks and other natural phenomena such as waterways which define their tribal territories. These landmarks are central to tribal identity and locate individuals as well as groups within the bounds of tribal territories. ${ }^{164}$

\footnotetext{
162 Sparks and Oliver state that Te Rangitopeora was 'evidently a woman with considerable control over property and land' and that on Kapiti she over-rode the opposition of Te Rauparaha and Te Rangihaeata (her uncle and her brother) and insisted on allowing William Mayhew to use a piece of land (1990a: 546).

163 Jones writes that, 'in Maori society it is considered a high compliment to be the subject of chastisement and castigation, especially in song' (1961:3).

164 According to Tamihana Te Rauparaha, the mainland opposite Kapiti Island had also, by the time of the creation of this composition, come to be known as Kapiti, 'Ko te ingoa nui o tenei pito o te motu
} 
The ocean imagery that is first introduced in line six with the naming of Raukawa is repeated in lines twelve to thirteen with Kahoki's invocation of Kapiti. The "currents of Raukawa moana" and the "crying mournful tides of Kapiti" are thus linked as important vehicles through which the magnificent imagery of the ocean is represented in the waiata. This ocean imagery is further consolidated by the mention of "te au pouri" in line nine. Raukawa moana, Raukawa iwi and Kapiti are connected via the ocean. The awe-inspiring vastness, power and importance of the ocean is also recalled through this imagery and lends a certain poignancy to the mournful aspect of the waiata, to the fact that it is a tangi. In thinking of the ocean we are reminded, for example, of the all-consuming power of nature and the relative weaknesses inherent in human life. Ocean imagery in this way reminds us that as individuals we are highly insignificant in comparison to the power of nature. Through the images presented in this and many other tangi, Maori are connected in death to the specific tribalscapes that they occupied, traversed and storied in their lifetimes. Maori are bound in death as in life to the spaces and places that define them, to the geography of whenua, moana, maunga and awa.

In addition to naming particular geographic features which locate the waiata within the physical and conceptual territory of the tribe, Kahoki names certain people and/or personifications in her waiata. The first of these appears at the very beginning of the waiata and directly addresses "Horo". There are multiple possibilities to whom or what this "Horo" applies. It could be another name for Te Rangitopeora or a shortened version for the place Horowhenua. ${ }^{165}$ Other possibilities include it being the name of a star or other celestial being which has a certain relevance within the context of the waiata. It might also be a combination of some or all of these things.

Further, on line eleven, Kahoki mentions Rongotakawiu which may refer to the famous Whakatau's father, the same tupuna named by Kahoki's brother Matene

nei, ko Whairarapa. No te nohoanga nei te Rauparaha ka riro nei tenei kainga i a ia, katahi, ka whaiho tenei ingoa, hei ingoa nui mo tenei pito o te motu nei Ko Kapiti' (Te Rauparaha 18?: 10).

165 I am grateful to Rawinia Higgins for pointing this out to me. 
Te Whiwhi in his manuscript and discussed in chapter four of this thesis. In line thirteen Kahoki in fact names Matene:

piti hoki kau mai nei a Matene ki te

kainga kaore ra he moke tangata tena ka

Kahoki here names her brother, the person who, besides herself, is perhaps the most personally and profoundly affected by Te Rangitopeora's death. That Matene is said within the context of the tangi to have been brought home by Te Rangitopeora's death underpins this fact.

Although the specific details pertaining to whom these names refer may have been lost over time, it is clear that they would have been known to the composer's audience at the time. Further research into these names may reveal more insights into their relationships with Kahoki and Te Rangitopeora and the wider whanau of Ngati Toarangatira and Ngati Raukawa.

There is no more an effective illustration which supports the arguments for an iwi reading of these tangi than the naming of Ngati Toarangatira at the very end of the tangi:

kainga kaore he moke tangata tena ka riro i te heke o Ngatitoa te hoki mai nei te hau ki te ao ei.

Kahoki here refers specifically to the early nineteenth-century migrations to the south, a major series of events in the history of Ngati Toarangatira, Ngati Raukawa and Te Ati Awa which was to dramatically re-shape their futures and fortunes. ${ }^{166}$ This reference to the migrations of Ngati Toarangatira, coming as it does right at the end of waiata, has the effect of centring Ngati Toarangatira history and traditions within the context of the waiata and thus links Te Rangitopeora inextricably with her

\footnotetext{
${ }^{166} \mathrm{Ka}$ 'ai-Mahuta writes that, 'The retelling of history is intrinsic to waiata, and this can be partly attributed to the emphasis placed on the past by Māori culture' and furthermore notes that 'Barrow suggests that Māori felt a 'nostalgic longing for distant homelands left and never to be seen again. Song and dance retold the legendary stories of the past, and recounted the deeds of famous ancestors, thus transmitting knowledge of the past from generation to generation" (1965: 7) (Cited in Ka'aiMahuta 2010: 116).
} 
tribal centre of Ngati Toarangatira. There is also a temporal and spatial dimension to this reference whereby a sense of time is again connected to a series of events and space is represented by movement from one place to another.

\section{Tangi tuarua}

The second tangi that Rakapa Kahoki composed for her mother Te Rangitopeora shares many similarities with the first tangi particularly in terms of its groundedness in a Raukawa-Toarangatira tribalscape. The tone of each tangi is similar as are their length and certain other features such as the sense of movement which is evident throughout the waiata. Particular imagery is shared in each waiata with subtle differences shaping the individual images employed in each waiata. These subtle differences make for more substantial differences in terms of the larger stories and histories to which they allude. The imagery employed in each tangi interweaves and intersects at crucial points of contact which serve to map out a specific physical, spiritual and conceptual landscape. The close reading that follows traces the broad contours of Rakapa Kahoki's second waiata tangi for her mother Te Rangitopeora from beginning to end with a particular focus on the tribalscape that the words of the waiata invokes.

The more direct tone of this second tangi is evident from the very beginning of the waiata whereby Kahoki positions herself within the immediate context of the waiata:

\footnotetext{
E kimi ana au, kei wea te ara inga

ro ai a Topeora, tena kataha ki te
}

Using a first-person voice Kahoki foregrounds the close relationship that she has with the subject of the waiata, her mother Te Rangitopeora, by conveying the image of herself seeking out where Te Rangitopeora has gone. Kahoki thus portrays herself as being directly and actively involved in searching for Te Rangitopeora. That Te Rangitopeora is also named in this first phrase (where she is referred to as 
"Topeora") makes the subject of the tangi explicit within the context of the waiata. This overt naming of Te Rangitopeora ensures that she is remembered for, as McKinnon notes "In the oral tradition everyone who is to be remembered is named. No name, no memory" (1997: Plate 9).

Within these first two lines Kahoki also alludes to the journey on which Te Rangitopeora has embarked through the use of the word "ara". The use of this word suggests that Te Rangitopeora's journey takes a particular route and furthermore recalls "Te ara tapokopoko o Tāwhaki" ("The billowy path of Tāwhaki", ie the Tasman Sea) (Smith 2001: 193). While Smith notes that, "The tides off the Taranaki coast greeted the spirits of the dead, who travelled westward on the outgoing tide to Hawaiki" (2001: 192), a similar belief whereby the wairua of the deceased travel westward on the outgoing tides to Hawaiki may also have been the case for Waikato peoples. ${ }^{167}$ In her study of waiata tangi from Taranaki, Smith furthermore notes that the theme of bidding the wairua of the deceased take the pathway to death is an old theme which may be depicted in physical terms as in the following examples:

te ara kore weu (the "rootless" path);

ko te papa i Te Apai hei ara mou (the flat land at Te Apai is the path for you);

te papa o Whareone to ara haerenga (go along the flats at Whareone) (2001: 215).

Smith furthermore notes that "these paths could be straight and uncomplicated... Or else they were winding...or dangerous and difficult... and were not without peril to the living...since they ran in one direction only":

te ara ka rere kore ki muri (the path that does not run behind) (2001: 215).

"Te Ara Whanui-a-Tane" ("The Broad Pathway of Tane") is a commonly heard euphemism for death which refers to the way by which the spirits of the deceased

\footnotetext{
167 A pepeha recorded by Taylor (1855: 128) and Williams (1908: 16; 1971: 365) and cited in Mead and Grove (2001: 164) may refer to the pathway to Hawaiki that wairua take upon death, 'Ka kotia te taitapu ki Hawaiki' ('The sacred tide to Hawaiki is cut'). A possible meaning is that the risks taken are tantamount to cutting all ties and possibilities of a peaceful journey to Hawaiki; hence death could be sudden'. This pepeha also suggests that Hawaiki is reached via the sea.
} 
are said to return home to Hawaiki. ${ }^{168}$ "Te Ara Whanui o Rehua" ("The Broad Pathway of Rehua"169) is another formulaic saying which refers to the pathway that the deceased take upon death. All of these references to ara point to a direction or route that the deceased are believed to have taken on their journeys following death.

A sense of being left behind and abandoned is also evident in that Te Rangitopeora is said to have gone while Kahoki, as the voice of the waiata, is left searching for her. This is echoed in the term "whanau pani" which is used to describe the immediate whanau of the deceased. ${ }^{170}$ Here, "pani" translates as "orphan" which echoes the loss felt by a child upon the death of their parent. The immediate whanau is in this way said to be so orphaned by the death of their loved one.

Kahoki's use of the word "ngaro" in this context adds a sense of Te Rangitopeora having moved into a different realm where the living cannot follow. In addition to meaning "lost", Williams gives the translations "passed into" (1971: 230) and "passed off or away, subsided" (1971: 230). Further translations of "ngaro" that Williams gives, for example, "hidden, out of sight, disappeared" (1971: 230), highlight a separation between te ao kikokiko and te ao wairua. The wider implication of Kahoki's use of the word "ngaro" is that Te Rangitopeora is gone from te ao kikokiko where Kahoki herself remains. The word "ngaro" is also

\footnotetext{
168 'Tahekeroa Te Ara whanui a Tane. Names of the way by which spirits of the dead descended to the underworld. The Ara whanui a Tane is the sun path, the sun glade along which spirits pass to Te Hono-i-wairua. This sun path is sometimes called the ara matua, a name that also denotes the ecliptic. Many of these old Polynesian myths are based upon astronomy' (Unknown author. 1926: 239-241). Tane is also the creator of humankind. This is remembered in the pepeha 'Wai o Tāne-pī' ('Water of Tāne-the-source'). The last drink taken by a dying person is called by this phrase. Thus the name of Tane as the creator is given recognition before departure (Mead and Grove 2001: 421).

169 'In summer (raumati) a bright star, called Antares or Rehua, appears. The cicadas that sing in warm weather were called Rehua's birds' (Keane 2009. Electronic source). 'Rehua is one of the gods, and also a constellation' (Burns 1980: 295). See also 'Rehua kai tangata ('Rehua destroyer of people'). Rehua is the summer star Antares, seen when the harvest is finished and men are free to join war parties. Also some losses resulted from the heat of summer, which was especially hard on the older people' (Mead and Grove 2001: 350).

170 The immediate family of the deceased are also referred to as the kiri mate or kura tuohu (Higgins and Moorfield 2004: 87).
} 
often found in expressions such as "te iwi ngaro"171 and "te iwi kua ngaro" 172 which appear in many waiata tangi and refer directly to the deceased. Such expressions refer figuratively to the dead as a collective group and therefore highlight the importance that Maori place on collectives and community as well as the belief that one is never alone in death. ${ }^{173}$

This sense of loss and also grief is further made manifest by Kahoki asking for the pathway or direction in which Te Rangitopeora has gone ("kei wea te ara i ngaro ai a Topeora"). The sense of direction suggested by the word "ara" is followed in the line three by reference to a specific direction:

ro ai a Topeora, tena kataha ki te

Hauauru he noho i kona kia tangi au ki

Kahoki here advises that the pathway which Topeora took tends to the west. This direction has particular relevance for Toarangatira, Raukawa and Ati Awa peoples particularly due to their having migrated from their homes in Waikato and Taranaki on the west coast of Te Ika a Maui to the south-west coast of Te Ika a Maui and further to Te Waipounamu in the early nineteenth-century. ${ }^{174}$ These peoples have for generations now made their homes on this western side of Te Ika a Maui. ${ }^{175}$ Many Maori euphemisms for death include references to night and darkness ("Haere ki te po", "Kua wehe atu ratou ki te po; ki te po uriuri, ki te po tangotango ki te po i oti

\footnotetext{
${ }^{171}$ As in 'Tērā te kakau' a waiata tangi by Te Ria Haukoraki (Ngati Raukawa, Ngati Toarangatira) (in Royal 1994: 60).

172 As in 'Takoto Ana Mai' a waiata tangi by Kaumoana of Pirongia (Waikato) (in Waikato-Tainui 2010: 25).

173 That is, your tupuna and all those who went before you beckon you when you die (Takirirangi Smith, 2012. Personal Communication) and the dead go or travel in groups ('tira', 'hunga') rather than alone (Rawinia Higgins, 2013. Personal Communication).

174 The peoples affiliated with Toarangatira, Raukawa and Ati Awa who migrated to the south settled between Whangaehu and Te Parinui-o-Whiti, and even on the Chattam Islands (McKinnon 1997: Plate 29). 'Their lands stretching from Rangitīkei to Wairau and Whakatū were described in the motto: 'Mai i Miria-te-kakara ki Whitireia, whakawhitia Te Moana-o-Raukawa, ki Wairau, ki Whakatū' (McKinnon 1997: Plate 29).

175 This was confirmed by various tatau pounamu (peace treaties) and other forms of truce between Ngati Toarangatira, Ngati Raukawa, Te Ati Awa and neighbouring tribes. This process was not without its own difficulties, however, with factions of the ART confederation sometimes turning on each other as hapu jostled for 'the better sites' (Burns

1980: 151).
} 
atu") with opposing references to light and day being associated with life. Of additional relevance here is the fact that the sun goes down in the west. The phrase "E to te ra", literally, "The sun has set", is a euphemism which plays on celestial imagery and uses the idea of cyclic movement from one state (of light/day-life) to another (of darkness/night-death). ${ }^{176}$ It follows that the western direction that Te Rangitopeora is said to have taken suggests that she has followed the path of the setting sun and has so crossed to the space of death.

Furthermore, a sense of journeying, movement and mobility is again apparent through the use of waka imagery. The image of the waka imbues a sense of movement and travelling which is suggested by their major function as modes of transport. The sense of Te Rangitopeora's wairua being free to visit places of significance to her, even if only through the imagining of the waiata that Kahoki composed for her, weaves into the Maori belief that after we vacate our physical human forms our wairua travel to Hawaiki. In regards to death, a sense of journeying and movement is shared by Maori all over Aotearoa New Zealand.

Images of waka are popular in both waiata aroha (see Mead 1969) and waiata tangi. In waiata 93 of Ngata's Nga Moteatea for example, the names of six waka:

Kia mate ia nei koe, e hika,

Ko Atamira te waka, ko Hotututaihirangi,

Ko Tai-o-puapua, ko Te Raro-tua-maheni,

Ko Araiteuru, ko Nukutaimemeha;

Ko te waka i hiia ai te whenua nui nei (Ngata 1961: 6-7).

This goes back to Ngata's description (p. xviii) “Ki nga waka o te tupapaku”. McRae and Jacob note that:

Ka tākina he whakapapa poto hei tuku i te rangatira taiohi nei kia haere i tana haere. He waka ngā mea e whakahuatia ake ana, à, ko taua taiohi pea kei te tauihu i a ia e ora ana. I konei ko te tūhono a te kaitito i te waka o te mate me te waka o te ora, e āhua rite ana ki tērā kōrero e tīkina nuitia ana hei whakatepe i te whaikōrero: 'Âpiti

176 Takirirangi Smith, 2012. Personal Communication. 
hono tātai hono, rātou te hunga mate ki a rātou, āpiti hono tātai hono, tātou te hunga ora ki a tātou. Ko te atamira te papa i takoto ai te tūpāpaku, he waka te hanga. Ko Hotutaihirangi te waka o Whiro, te atua o te mate. Ka whakaarahia ake ngā tūpuna i heke mai ai ki Aotearoa, ko Āraiteuru tērā, te waka i ū ki Te Waka-a-Māui, ko Nukutaimemeha anō tērā, i hīia ake ai e Māui a Aotearoa, Te Ika a Māui. Kei konā anō pea te ata o te whakataukī rā, "Toitū te whenua, whatungarongaro te tangata" (2011: $72 \& 74)$

The young chief is sent on his way with a short whakapapa or recitation of names. These are of canoes, intimating that he was at the prow of them in life. Here the composer's linking of canoes associated with death and life is akin to the acknowledgement made in the chanted refrain commonly used by speakers to conclude whaikôrero (formal speeches): 'Joined together now are the genealogical lines, the dead to the dead and the living to the living.' The atamira is the canoe-shaped platform on which the dead were sometimes placed, and Hotutaihirangi, the canoe of Whiro, personification of death. The migrating ancestors are revivified in naming Âraiteuru, which landed in the South Island, and Nukutaimemeha, the canoe from which Māui fished up the North Island - leaving a hint of the proverbial 'People go but the land remains' (2011: $73 \& 75)$.

This mention of the west might also refer to the direction that Te Rangitopeora's wairua takes in order to return home to Hawaiki. ${ }^{177}$ This relates to Maori beliefs pertaining to death whereby a person is said to return to Hawaiki upon their departure from te ao kikokiko ("Hoki atu ki Hawaiki nui, ki Hawaiki roa, ki Hawaiki pamamao"). Hawaiki is said to be the place from which Maori came to ultimately settle in Aotearoa and it is believed that Maori return to Hawaiki after death. Kahoki might here be alluding to the west-ward journey that Topeora has begun as her wairua travels home to Hawaiki. ${ }^{178}$

\footnotetext{
177 The final phrase of the first part of a waiata tangi said to have been sung at Te Rauparaha's tangihanga reads, 'Ka maunu te Taniwha, i te rua/I murua atu i te uru'. This is translated by Bill Parker as 'The denizen (chief) has left his lair/And departed from the west' (cited in Burns 1980: 294-295).

178 This might also be linked to the westward 'Path of Tawhaki' (ie The Tasman Sea). Orbell argues that while Hawaiki is generally located in the east, it being identified with the life-giving force of the
} 
An overall sense of movement and action is evident in these opening lines of the waiata. This is felt through the composers expression of searching for the way which Topeora has travelled. This reinforces the notion of Te Rangitopeora's wairua having embarked on a journey and is mirrored by the waiata itself which leads the listener/reader on a journey of their own. Certain places and features of the naturescape are named in the waiata which mark crucial points of geographic reference. Kahoki effectively takes the listener/reader on a journey through a naturescape which is of special significance to Ngati Toarangatira and Ngati Raukawa. The contours of this naturescape are tribally defined and rooted in the territories of Ngati Toarangatira and Ngati Raukawa. In discussing classes of Maori songs, Ngata writes:

Tera ano tetahi momo waiata e tika ana kia taka ki raro i te rarangi o te patere, e kiia nei he waiata poi; ehara i te mea he waiata hei rangi poi haka nei, engari ko nga kupu i poi haere ki runga ki nga iwi, e whakataki ana i te kawai tangata, i te kawai whenua ranei, i nga parekura, i nga mahi a nga tipuna (1972: xii).

Pei Te Hurinui translates:

There is another group of songs which properly comes under the designation of a patere, it is called a poi...song. It is not necessarily a song for the poi dance or haka...but the words as it were skim over the tribes, in pursuit of genealogical links, or takes a spiritual journey over various territories, or battle grounds or is a recital of the deeds of ancestors (Ngata 1972: xviii).

While Kahoki's waiata can be said to belong to a class of waiata broadly referred to as tangi or laments, it can also be said to share some features with patere and kaioraora. Through the references in her waiata to specific places Kahoki's waiata takes a spiritual journey and picks up on particular genealogical links, various territories and ancestors. All of these furthermore combine in her astute use of metaphor and word-play within the text.

sun' (1985: 18), it was also associated, 'at least by implication, with the sun setting in the west (1985: 19). 
This is befitting of both the whakapapa and lived experience of Te Rangitopeora. It is at this point in the waiata that the first direct expression of grief is made:

Hauauru he noho i kona kia tangi au ki

a koe, ma konei, taua ki te maunga

Within the context of the waiata Kahoki takes a moment here to pause and grieve for Te Rangitopeora. This sense of pausing is conveyed in the phrase "he noho i kona" before "kia tangi au ki a koe". The voice of the waiata correspondingly changes from talking about Topeora ("kei wea te ara i nga/ro ai a Topeora") to directly addressing her ("kia tangi au ki/a koe"). The expression of mental and physical grief which is conveyed in the word "tangi" is connected to the fact that the vehicle through which the composer expresses her grief is a waiata. ${ }^{179}$ The expression of grief is expressed much more directly in this second waiata tangi than it is in the first waiata tangi. Where the word "tangi" appears in the first waiata, for example, it is used in a figurative way which calls on the imagery of ocean and landscape to convey its sense of meaning ("e tangi tiari maira te tai o Aka/piti"). Although the meaning is clear the language is highly poetic. The combination of the way in which the word "tangi" is used and the direct form of address that the voice of the waiata uses make for a more direct approach in this waiata than in the first waiata tangi that Kahoki composed for Te Rangitopeora. The sense of pausing in grief is ultimately fleeting as the notion of journeying and movement is again taken up:

a koe, ma konei, taua ki te maunga

Huka, e tu maira kei takahia

Kahoki here imagines herself and Te Rangitopeora travelling together to Maungahuka, a mountain peak which is located in the Tararua ranges

179 Tamihana Te Rauparaha writes simply 'tangi' rather than 'waiata' or 'waiata tangi'. This could be because it's implicit in the meaning of tangi; 'to sing a dirge' or 'lamentation, mourning, dirge'

(Williams 1971: 379). 
('maunga/Huka'). ${ }^{180}$ That Kahoki has them travelling together to this maunga infuses a sense of freedom within the confines of the waiata. The naming of this maunga dually invokes tribal lands through the naming of such a specific tohu whenua as Maungahuka. ${ }^{181}$ Maunga are important symbols and physical manifestations of tribal mana and identity hence their prominence in tribal sayings (pepeha) and formulaic modes of introducing oneself and of self-identifying. ${ }^{182}$ Kahoki's naming of Maungahuka correspondingly positions both herself and her mother within a particular Raukawa-Toarangatira landscape. The tribalscape which begins with Kahoki's mention of "te Hauauru" and is extended by her naming of "Maungahuka" is consolidated further in her naming of Waikato:

Huka, e tu maira kei takahia

koe te ia no Whaikato e pai ana

Kahoki's naming here of Waikato echoes line six of the first waiata tangi where she mentions the currents or tides of Raukawa ("te ia no Raukawa"). Similarly this mention of Waikato could refer to both the waterway, the Waikato river, and the people of Waikato. In terms of its being a waterway, the Waikato river is the longest river in Aotearoa New Zealand at 425 kilometres:

It begins on the slopes of Mt Ruapehu, draining into Lake Taupō and exiting at the north-east. After...passing through lowlands between Cambridge and Mercer, it turns westward, entering the Tasman Sea at Waikato Heads. The Waipā River, which rises in the King Country, meets the Waikato River at Ngāruawāhia (Swarbrick 2010. Electronic source).

\footnotetext{
180 See http:// www.nztopomaps.com/16437/Otaki-Forks/Wellington. The Maungahuka stream also runs close by. The peak stands at $1130 \mathrm{~m}$ elevation.

${ }^{181}$ Further research might elucidate more connections between this particular mountain or peak and Raukawa-Toarangatira people.

182 Mead notes that: 'In Maori chants, a mountain which is associated with a particular locality and a particular group of people is a symbol of somewhat the same order as a flag. A mountain represents the group and its geographic domain, as in the saying: Ko Waiapu te awa, ko Hikurangi te maunga, ko Ngaati Porou te iwi' (1969: 383). McKinnon notes that: 'In petitioning leaders from throughout the country, the protagonists of the King movement wove a web of unity and relationship in a distinctive Māori way. Subsequent pledges by tribes of their mountains as foundations upon which the King movement might stand symbolised the unifying of independent tribes without compromising their independent rangatiratanga' (1997: Plate 36).
} 
The river provides both physical and spiritual sustenance for Waikato-Tainui peoples living along its banks:

The spirits of ancestors were said to mingle with its waters, which were used in rituals. Orators addressed it as having a life-force of its own. It was a source of food, including eels, mullet, smelt and whitebait, and plants like watercress. It was an important waka (canoe) route, especially from the mid-1800s when Māori began taking their farm produce to distant markets (Swarbrick 2010. Electronic source).

Like Raukawa moana, the Waikato river is a powerful symbol of the mana of those who manage and control its resources and use as a means of transportation.

The importance of the Waikato river to the iwi who live around it is perhaps best exemplified in its being, like Raukawa, a key marker of tribal identity. This is no better exemplified than in the pepeha "Waikato taniwha rau, he piko he taniwha, he piko he taniwha" ("Waikato of a hundred taniwha. At every bend a taniwha can be found") (Royal 2012b. Electronic source). This pepeha pertains directly to the Waikato river and to the people who live around it and claim it as theirs. The taniwha in the pepeha are said to represent chiefs or other persons of great importance. The pepeha thus relates to the many great chiefs, leaders and other influential people who affiliate with the wider Tainui confederation of tribes. ${ }^{183}$ The Tainui confederation includes Ngati Raukawa and Ngati Toarangatira who both trace descent from the Tainui waka. The reference to Waikato in Kahoki's waiata tangi thus recalls the multiple and intersecting relationships which exist between Ngati Raukawa and Ngati Toarangatira and all the other tribes who affiliate to the Tainui waka. Furthermore, the Waikato river enters Te Ara Tapokopoko o Tawhaki, the Tasman Sea, on the west coast of the Te Ika a Maui. The inclusion of Waikato as part of Te Rangitopeora's journey could also be relevant in the journeying of Rangitopeora on her "ara wairua" to Hawaiki.

\footnotetext{
183 '“Mai i Miria Te Kakara ki Whitireia whakawhiti te Moana o Raukawa ki Whakatu ki Wairau." This statement emanated from Te Rauparaha. It is Ngati Toa's pepeha or statement of identity to other Maori tribes. It is saying that from Rangitikei in the Manawatu to Whitireia (the mountain overlooking Mana Island), across Cook Strait to Nelson and the Wairau - that this is Ngati Toa's mana tangata, mana whenua, and mana moana' (Solomon 2003: 8).
} 
In addition to the relationships which are recalled through the phrase "te ia no Waikato" the greater geographic area which is also known as Waikato is invoked. The Kawhia land and seascape in particular is considered to be the first homeland of the Tainui peoples. ${ }^{184}$ It was here in Kawhia that the Tainui waka made its final landing in Aotearoa and it was due to the food-rich waters of Kawhia harbour and of the fertile surrounding lands that Tainui peoples first settled here hence the pepeha "Kawhia moana, Kawhia kai, Kawhia tangata" (Royal 2012b). At the time that Kahoki composed her tangi, the Raukawa-Toarangatira-Awa migrations from Waikato and Taranaki to the south were still very recent history and the strong links of kinship that these iwi and hapu shared with their relations who remained in these tribal homelands were fluid and dynamic. Te Rangitopeora herself was born in Waikato and travelled south as a part of these early nineteenth-century migrations (Sparks and Oliver 1990a: 546). The reference to Waikato within the waiata thus recalls an extensive tradition of shared history and relationships.

The relationships that the peoples of Tainui share are suggested within the waiata in the way that Kahoki's reference to Waikato directly follows her mention of Maungahuka, that is, within the context of the waiata, the listener/reader is taken from Maungahuka to Waikato. This has the effect of making the connection between these two places and the people in them overt. This is reinforced in the language of tohu whenua whereby the connections are figuratively made through the naturescape from maunga to awa. Following the reference to Waikato the waiata contemplates Te Rangitopeora's status within her iwi:

koe te ia no Whaikato e pai ana

kia matakitakina koe te rau o te iwi

Here Te Rangitopeora is praised as "te rau o te iwi", an expression of endearment which has similar meaning or significance as other phrases such as "te rau o te huia" and "te rau o tītapu" (Williams 1971: 328). Here "rau" literally refers to a plume of feathers but it is used as in the above examples only in relation to the feathers of

184 McKinnon rather eloquently refers to Kawhia as 'the enduring centre of the house of Tainui' (1997: Plate 19). 
certain rare and therefore extremely precious birds. The huia, for example, were highly prized for their distinctive black and white plumes. ${ }^{185}$ Huia are now an extinct species and would have already been rare in the nineteenth-century. ${ }^{186}$ Similarly the kotuku (white heron), from which the plumes known as titapu were taken, were and are still rarely seen hence the whakatauki, "He kotuku rerenga tahi i te tau" ("The white heron of a single flight in the season"). ${ }^{187}$ The plumes of both of these birds were highly prized items and were worn by rangatira and others in the upper echelons of Maori society. In her waiata Kahoki draws on a comparison between these highly prized items and Te Rangitopeora. Te Rangitopeora is thus figuratively referred to as "the precious plume of the people". This honorific term is befitting of Te Rangitopeora's mana and the regard with which she was held by her people. ${ }^{188}$ This sentiment is furthermore extended in the lines which follow:

mo ngatahua, ngaro i to papa uta ina

atu ra ki te ihu o nga wakataurua

The image of a waka echoes the mention of a waka in line four of the first waiata tangi. A sense of journeying is again apparent in the use of this image which is emphasised by the mention of "nga tahua", "the provisions" which will see Te Rangitopeora through her impending journey. That these provisions are said by Kahoki to be so numerous that the ground is unable to be seen emphasises Te Rangitopeora's mana in that such provisions would only have been made

\footnotetext{
185 In a photographic portrait of Te Rangitopeora taken by an unknown photographer ca 1840, she appears with Huia feathers in her hair, a kaitaka cloak with its richly patterned taniko border, and large, impressive tiki pendants (1/2-058452-F, E. S. Richards collection, Te Whare Pukapuka o Alexander Turnbull, Alexander Turnbull Library). McRae and Jacob additionally note that these adornments 'katoa ēnei he tohu nō te rangatira, he taonga anō i noho mai ki te reo whakaahua o ngā mōteatea' (2011: 55) ('are marks of her rank, and also the subjects for imagery in the songs' (2011: 55)). See also Lindauer's painting of Te Rangitopeora in (Cowan 1930b: 167).

186 'The last confirmed sighting of a huia in the wild was in 1907, although unconfirmed sightings were reported for twenty to thirty years after that' (http://collections.tepapa.govt.nz/theme.aspx?irn=1339).

${ }^{187}$ Mead and Grove explain that, 'This familiar saying is used for a rare visitor, often one of importance' (2001: 89).

188 The word 'rau' may have additional significance to Raukawa peoples as it appears in the tribal maxim 'Motai tangata rau' ('Motai's hundred progeny'). Motai was a renowned ancestor of the Tainui tribes and is a fourth generation descendant of Hoturoa. Motai is also the tekoteko of the wharenui at Raukawa marae in Otaki. 'Rau' could furthermore be a play on words as a shortened of 'Raukawa'.
} 
available for a high-born and well-regarded rangatira. The notion of taking provisions in these waiata tangi is common and are part of the mourning process: "he ō matenga" were given to the dying but in some instances, particularly in the case of rangatira, kai was placed into the waka tupapaku as provisions for their journey to te po (Best 1905: 162). The wakataurua which are mentioned add to this image due to their being waka which were specifically used to convey provisions. ${ }^{189}$ Nineteenth-century ethnographer Elsdon Best writes that wakataurua were double canoes which were used for more temporary purposes than waka unua which were used to journey over long distances (1976: 32-33). This aligns with the temporary use for which such a waka would be used as in the case of Te Rangitopeora's death: a more permanent waka is not needed due to mourning being a temporary state. The image of Te Rangitopeora journeying in a double hulled canoe also alludes to one hull being used to convey her tupapaku and the other for kai thus separating tapu and noa.

In Maori society the ability of rangatira to provide food for their people was of utmost importance, so much so in fact that prior to sustained European contact, pataka, food storehouses, are said to have been more prominent signs of chiefly mana than whare whakairo. ${ }^{190}$ The importance of food and the ability to obtain and provide food and thereby sustenance was indicative of chiefly mana. This is also seen in Tamihana Te Rauparaha's writing where he notes that the three things which drew Te Rauparaha to the south were kai, Pakeha and pounamu. ${ }^{191}$

It is important to note that waka were not only used as water-going vessels which conveyed people, provisions and other items. Maori anthropologist Te Rangihiroa, also known as Peter Buck wrote, "Sections of a canoe hull containing

\footnotetext{
189 Wakataurua are specifically used for the transportation of food (provisions) (Takirirangi Smith, 2012. Personal Communication). Although in waiata 200 of Ngata's Nga Mōteatea (He tangi mō Te Aokapurangi nā Rangiwawahia; Te Arawa), the English translations of lines 15, 16 and 17 (E tū ana koe,/Ngā waka taurua/I a Tainui, i a Te Arawa) are given as 'For you do stand/Athwart both canoes,/Tainui and Te Arawa' (cited in McRae and Jacob 2011: 154-155).

${ }^{190}$ Hirini Kaa writes that in the early nineteenth-century 'the most commonly decorated structures within a pā were pātaka (storehouses). Repositories of nutritional sustenance for the whānau and hapū residing in the pā, it was perhaps unsurprising that these were also symbolically important structures, and were the major beneficiaries of the decorative arts' (2012: 27).

191 Te Rauparaha (18?: 11).
} 
bones have been found in caves" and "Smaller wooden troughs containing bones and termed waka tupapaku have also been found in caves" (1970: 424). Waka koiwi were carved, wooden bone chests which "are shaped to represent conventional human figures with a large hollow body, a small head, and small limbs" (Buck 1970: 424). Waka huia were smaller, carved wooden "boxes" which held huia feathers and other taonga. The image of the wakataurua also harkens back to Waikato in that it recalls "te ia no Waikato", the watery currents of the Waikato river. This connection between the Waikato river and "nga wakataurua" has the effect of consolidating the sense of Te Rangitopeora's journeying in te ao wairua. The sense of progressive movement from Maungahuka in the south to the Waikato river and area takes an interesting turn in the lines which immediately follow:

$$
\begin{aligned}
& \text { tahuri mai nei to kanohi ki te } \\
& \text { ware tonga ki nga paenga, riri }
\end{aligned}
$$

The progression of Te Rangitopeora's journey from Maungahuka to Waikato is halted while she is instructed by the voice of the waiata to turn her head to the south. The listener/reader is in turn compelled to follow the direction set by the composer and turn their thoughts to the south and to some of the major events that were happening there at the time. Battle and conflict are invoked in the mention of the "paenga riri" or "heaped up corpses of war". ${ }^{192}$ Conflict in the southern areas that Ngati Toarangatira, Ngati Raukawa and Te Ati Awa now occupied was indeed a weighty issue of the day as were conflicts over land all over the country at this time. "Paenga riri" furthermore recall battlefields as well as armies, denoted by lines of soldiers and heaped up corpses which indicates more wider losses than those suffered by Raukawa-Toarangatira peoples in the south. This is emphasised by the following line, "Ka hinga te Pakeha". The tribalscape of the people is here analogus to the land: "Turn and look towards the south, to the land and people who alongside your brother have fought". In such times of conflict, the people turned to their

192 Takirirangi Smith, 2012. Personal Communication. 
rangatira for guidance and leadership. It is a further measure of Te Rangitopeora's mana and influence that the voice of the waiata calls these issues to her attention. It is also of some note that Te Rangitopeora was a woman whose mana in things martial and political was evidently so highly valued. This reference to the conflict that her people were involved in is made in even more explicit in the lines which follow:
ki to tungane turia ai i te awa
tea ka hinga te Pakeha he waka
mutunga mahi te iwi ka ngaro nei e.

Kahoki here makes reference to a close male relative of Te Rangitopeora's ("to tungane"). Although he is not specifically named, Kahoki's mention of the "awa/tea" infers that Kahoki is here referring to Te Rangitopeora's brother, Te Rangihaeata. The word "awatea" means "broad daylight" or "middle of the day" and Te Rangihaeata's name can be interpreted as "The dawn sky". ${ }^{193}$ Te Rangihaeata was a formidable warrior and leader who achieved much success alongside his uncle Te Rauparaha. Burns writes that “Te Rangihaeata was a big, good-looking young warrior of immense strength and great courage, who often acted as his uncle's second-in-command. He was also...an authority on tribal history, waiata and carving" (1980: 154). ${ }^{194}$ Te Rauparaha and Te Rangihaeata indeed made a formidable combination with the talents of each complementing the other.

Within the context of the waiata Te Rangitopeora's tungane is associated with "nga paenga riri". This is made clear in the repetition of the phrasing which begins after "tahuri mai nei to kanohi" and ends with "ki te/tonga ki nga paenga, riri/ki to

\footnotetext{
193 Williams gives three meanings of 'haeata': 'dawn', 'bright arch in the horizon when the sky is overcast' and 'beam of light entering any dark place' (1971: 29). The word 'rangi' refers in this instance to the sky. 'Even though Te Rangihaeata is said to have died in 1855 (Ballara 1990: 491), some ten or more years before Te Rangitopeora's death between 1865 and 1873 (Sparks and Oliver 1990a: 547), the waiata might refer to Te Rangihaeata in a poetic way which recounts some of the actions he took when he was alive. The phrase 'ka hinga te pakeha' supports the notion that the reference is being made to Te Rangihaeata as he was openly opposed to Pakeha encroachment on to Maori lands and resources.

194 Te Rangihaeata composed a waiata aroha, 'Taku Waka Whakairo', for Te Rauparaha which laments Te Rauparaha's capture and arrest by Sir George Grey (Royal 1994: 102-106). Ironically, the text of this waiata was copied from the books of Sir George Grey (Royal 1994: 102).
} 
tungane". The thrice repeated preposition " $\mathrm{ki}$ " emphasises the connectedness between events in the south, "the heaped up corpses of war". These points of focus are furthermore connected to conflict with Pakeha. In this final section of the waiata the composer thus draws attention to wider issues of social and political significance which affect the iwi living in the south. This referencing of wider events which affect the iwi takes the waiata much further beyond a personal statement of grief from the composer, Kahoki, to Te Rangitopeora and expands the perspective of the waiata exponentially.

\section{Conclusion}

Rakapa Kahoki's tangi for her mother Te Rangitopeora are deeply challenging poetic texts which convey a wealth of meaning. In her tangi Kahoki draws upon complex imagery and metaphors which speak both to a wider Maori cultural paradigm as well as a more singularly defined tribal centre. Kahoki constructs a uniquely Raukawa-Toarangatira tribalscape through the words of her tangi which anchors her compositions firmly within the broader intellectual traditions of Ngati Raukawa and Ngati Toarangatira. Kahoki's tangi show that waiata are historical sources which, though expressed with fewer words, are just as rich in meaning as longer narratives such as the manuscripts written by her whanaunga Tamihana Te Rauparaha and Matene Te Whiwhi explored in sections one and two of this thesis. In her tangi Kahoki locates her identity through complex articulation of her whakapapa and tribalscape and highlights the mana of Ngati Raukawa and Ngati Toarangatira. 


\section{CONCLUSION: E noho ana au i te koko o toku whare}

...the whare whakairo must be filled with people if its meaning and function are to be made clear. The living link is vital to the survival of Ngā Kōrero Waihanga a Ngā Tipuna. Without the people at the feet of the ancestral poupou, the cycle of energy and transfer of spirit is incomplete. In Māori belief even the gods wither and die if people forget to worship them (Melbourne 1991: 133).

As I sit inside the house, the whare whakairo that is this thesis, I contemplate the art, the ancestors, the stories, the histories and all the richness that is the whare whakairo. From this position, inside the house, in the realm of Rongo, my voice as a female descendent of the poupou has a platform from whence I can speak and reaffirms my own whakapapa and my relationship to the house.

One of my primary intentions in this thesis is to alert readers to the wealth of Raukawa-Toarangatira written traditions which were created around the time of our first interactions and encounters with tauiwi and the skills of alphabetic reading and writing. Through examination of the "exotic" poupou of this whare, the published work which was created by non-Maori about Maori discussed in chapters one and three, I have shown how our korero has been interpreted by people from other cultures within their own specificities and contexts and with their own accompanying motivations. These chapters peel back some of the dense overgrowth which has formed largely undisturbed around the primary texts of our tupuna and cast some light on how and why this undergrowth has formed. In the early 1990s, Irihapeti Ramsden wrote:

Aotearoa is a complex and ambiguous society in which each individual is the inheritor of the stories of this place. They belong to all of us, and we belong to them, but we need to understand them all very much better if we want to live within this country with ease, and if we wish to create a healthy place for all our mokopuna (Ramsden 1993: 243). 
Chapters one and three of this thesis tie in to Ramsden's assertion in regards to understanding the stories of this place. It is important that we recognise that some of the stories which have been told about us and to us have been filtered through the lens of different cultures and individuals with their own motivations and agendas. These chapters clear some much needed intellectual space whereby readings of the primary writings of our tupuna are drawn free and clear from the overgrowth which has sprung up around them and contextualise the manuscripts within broader movements which were afoot at the time which saw Maori people intellectualised for the first time with pen on paper. Chapters one and three have been influenced by recent developments in the history of the book and a movement, more broadly in New Zealand and Indigenous history, toward retellings of history from Indigenous perspectives.

The core work of this thesis is revealed in chapters two, four and five whereby the magnificent complexity and beauty of the written texts of Tamihana Te Rauparaha and Matene Te Whiwhi and the texts of two tangi composed by Rakapa Kahoki are examined. These chapters explore ways of reading not only the writing of our tupuna but the important ancestral voices who live on in waiata and other forms of oral composition. These chapters assert the birth, or perhaps more accurately, the rebirth of Indigenous readers and build on the work such literary scholars as Penny van Toorn (2006) and Robert Nicole (2001) who challenge us to read Indigenous texts within the unique socio-political contexts in which they were created. The works of other Indigenous scholars from the Anglophone world who work with historic Indigenous texts, particularly those who work on their own tribal literatures such as Lisa Brooks (2008), Craig Womack (1999), Daniel Justice (2006b) and Robert Warrior (1995) have been of great use in this study. Closer to home, scholarship which has emerged from within the great sea of the Pacific Islands has been influential including the voices of such scholars as Albert Wendt (in Hereniko 1999) and Hereniko (1999) through to Maori scholars, writers, practitioners and community workers from the generations of Apirana Ngata $(1928 ; 1940 ; 1950 ; 1961 ; 1972 ; 2006)$ to the karanima and karanipa of my own 
generation such as John Rangihau (1992) and Irihapeti Ramsden (1993), all the way to contemporary scholars such as Alice Te Punga Somerville (2012), and Nepia Mahuika (2009; 2010).

In chapter one I argued that Tamihana Te Rauparaha's manuscript about the life of his father has variously been appropriated, mined for information and edited and re-presented to the public in various forms in both the Maori language and in English language translations. Specifically, I explore the ways that W. T. L. Travers (1872), John White (1890), T. Lindsay Buick (1911), George Graham (1915-1918), Peter Butler (1980), Patricia Burns (1980) and Heni Collins (2010) use Tamihana's manuscript in their published biographies of Te Rauparaha and, in the case of Graham, how Graham interacted with Tamihana's manuscript as an English language translator. The history of the manuscript is also bound up with George Grey, the larger than life British colonial administrator and governor who most likely commissioned its creation, who added it to his own personal library and in whose special collection it remains today. Tamihana Te Rauparaha's manuscript is yet to be presented in a published form in a way which appropriately frames and contextualises its own complex history and in a way which recognises the authorial agency of the writer, his unique subject position as the son of his main subject and the tribal perspective from which it is written.

Chapter two examines two key ways in which Tamihana Te Rauparaha's authorial agency is expressed in his manuscript about the life of his father. The ways that Tamihana writes himself into the narrative are tracked through the manuscript as are Tamihana's observations about the act of writing within the context of the manuscript. Tamihana's writing reveals a complex set of relationships at play due to Tamihana being the son of the subject about whom he writes, due to Tamihana writing about events at which he is sometimes present, sometimes not present and earlier in the manuscript, writing about events which preceded his own birth. Tamihana's observations about the act of writing as noted through several particular examples where writing features as a key causative element in the narrative illustrate the complex interactions which the written word facilitated as well as the 
complex ways in which the written word was being deployed in the early to mid nineteenth-century in Aotearoa New Zealand.

In chapter three I review George Grey's publications Ko nga Mahinga a nga Tupuna Maori and his English language translation of the same known more commonly by its shortened title, Polynesian Mythology, and examine Grey's use of a manuscript written by Matene Te Whiwhi as source material. Grey drew on a number of Maori texts which he collected during his terms as governor in New Zealand but edited the primary texts to fit his own underlying political aspirations and colonial ideology.

In the fourth chapter I return the focus to one of Matene Te Whiwhi's manuscripts which George Grey drew heavily on in his works of Maori mythology, Nga Mahinga and Polynesian Mythology. In this chapter I explore the functions and forms of the whakapapa that Te Whiwhi writes into his manuscript. Te Whiwhi includes whakapapa which frame his wider narrative and dually link the smaller narratives contained within his manuscript but more than acting as merely linking devices, I argue that the whakapapa themselves can be read as narratives or metanarratives. The whakapapa in Te Whiwhi's text illustrate a complex web of relationships which relate the narratives to the atua and to each other and moreover anchor the narratives in a tribal framework. The whakapapa run in all directions horizontally as well as vertically from tuakana to teina as well as in the other direction from teina to tuakana. This chapter explores some of the possible deeper meanings which can be elucidated from whakapapa which were written into manuscripts in the early to mid nineteenth-century.

Chapter five offers close readings of two waiata tangi texts composed by Rakapa Kahoki. This chapter explores the poetic and stylistic features of Kahoki's tangi and pays particular attention to the features which anchor Kahoki's compositions in a specific tribalscape. Kahoki's densely rich use of imagery, metaphor and poetic illusion combine in her relatively short and terse compositions to culminate in works of the highest poetic order. Kahoki's poetic genius is thus laid 
bare in these, her incredibly personal yet also very public declarations of her grief at her mother's death.

In the preface to Pei Te Hurinui Jones and Bruce Bigg's comprehensive bilingual work of tribal history, Nga Iwi O Tainui, Dame Te Atairangikaahu, the Maori queen wrote:

The Bible says that in the beginning was the word. My people say that the world of all meaning pre-existed before words ever came to be. If words are not the beginning in our sense they are certainly a connection. Not the only one, but a certain route from now to then and into the world of understanding of which the present is our first knowing. We look upon these words as the living presence of our tupuna and so they are a living taonga for us all (2004: xiii).

Following Te Atairangikaahu, this thesis recognises the primacy of thought before words but dually that the connections provided by words, the whakapapa which is enabled specifically through the form of the written word, has had and continues to have a huge influence in Maori lives. As Maori view the world differently to the ways that other peoples view the world, it should be of no great surprise that our literature is different to that of other peoples both in form and style as well as content. ${ }^{195}$ Regardless of the fact that our orthographic system was devised by non-Maori and that Maori were taught how to read and write by non-Maori, by the mid nineteenth-century Maori all over the country had taken up the practices of reading and writing and adapted these practices to meet their own needs. It is also clear that Maori experimented with and incorporated particularly Maori forms of expression and communication in their writing. ${ }^{196}$ Copious examples of this kind of exploration and extension of the written word to include what had previously been only oral forms of language are found in the nineteenth century Maori language newspapers, in correspondence, in manuscripts and other examples of early Maori written texts on a huge array of subjects.

\footnotetext{
195 See Ka'ai and Higgins (2004) for a clear and comprehensive exposition on Maori world-view. 196 See McRae (2002) for an insightful exploration of what she calls 'the oral tradition' in nineteenth century newspaper writing, for example.
} 
What is sorely lacking in the scholarship, however, is a literary theory that can account for the Maori cultural perspective inherent in these writings. In explaining her use of the term "Maori oral literature" Jane McRae, herself an experienced scholar of early Maori-language texts, points out that:

The term oral literature seems contradictory but advises distinctiveness. The genres are not typical of literary studies. They are waiata, kôrero, whakapapa, and whakataukī. They may be 'literary' in the sense of being of fine quality, but they cannot be categorised as the fiction or non-fiction of literature, for fact and fiction often interweave (2004: 133).

McRae here attempts to fit examples of early Maori-written versions of traditional Maori histories and stories into a literary studies framework which does not take Maori cultural perspectives into account. Although McRae does not overtly state that the paradigm within which she is working is specifically English literary studies, it is clear that she positions her work according to a specifically English literary centre. McRae furthermore attempts to reconcile the worlds of difference that exist between English literature and Maori literature by using term "oral literature", a term which she herself admits to be rather contradictory: waiata, korero, whakapapa, and whakatauki may not be genres typical of English literary studies, but they certainly could be called typical of Maori literary studies. Similarly, the categories of fiction and non-fiction do not work in a Maori literary framework simply because they are not useful or significant within the realm of a Maori or Maori centred literary framework.

Following Native American literary scholar Craig Womack, I argue that Maori communities have their own intellectual and cultural traditions that are well equipped to analyse Maori literary production and that these traditions should be the eyes through which the texts are viewed (1999). Early Maori written texts themselves offer a wealth of clues and possibilities within them for how we might meaningfully approach, engage with, and study them. Maori people and communities offer another crucial historically and contemporarily underused resource. Further, I locate this thesis within a Raukawa-Toarangatira tribal context 
which recognises Raukawa-Toarangatira voices and the tino rangatiratanga of Raukawa-Toarangatira people. This focus on iwi literary theory is motivated by arguments for Maori history to exist exclusively within the tribal conceptual framework ${ }^{197}$ coupled with the calls of Native American Literary theorists for studies of Indigenous topics to engage deeply with the contexts of iwi and place. ${ }^{198}$

There are many exciting possibilities for more work which follows the lead of Apirana Ngata's Nga Moteatea to be undertaken by Maori scholars. There is much still to be done, for example in the area of women's writing. Jenny Lee's three articles in Tu Tangata magazine which explore letters written by Ruta Te Rauparaha and Pipi Te Whiwhi offer exciting prospects for more work on early Maori women's writing within the genre of correspondence (1985; 1986a; 1986b). Such projects feed more broadly into the work of historian Charlotte Macdonald and publisher Bridget Williams and their work on the lives of early New Zealand women (1991). Work which relates more directly to Ngata's Nga Moteatea may include scholarly analysis of waiata and haka in contemporary kapa haka. Dee Acushla O'Carroll's MA thesis which offers a comparative exploration of the commercialisation of Hawaiian hula and Maori kapa haka breaks new ground in this important area of contemporary Maori and more widely Pacific creative and artistic modes of expression (2009).

Much work remains in the archives where, in the George Grey collection alone, thousands of manuscripts written by tupuna Maori from all over the country lie on the shelves waiting for reconnection with te ao marama and living descendents. Issues of our contemporary times concerning access, intellectual property and preservation abound in addition to the complications of historical context of collection and treatment in other earlier times by earlier researchers, writers and scholars. Much exciting work around the nineteenth century niupepa Maori, the Maori language periodicals has been produced over the past decade which has culminated thus far in Lachy Paterson's book Colonial Discourses: Niupepa Māori 1855-1863 (2006) and Jenifer Curnow, Ngapare Hopa and Jane McRae's

\footnotetext{
197 See Keenan 2008.

198 See Womack (1999); Justice (2006b); Weaver et.al (2006); Womack et.al (2008). Also see (Loader 2008: 21-22).
} 
Rere Atu, Taku Manu!: Discovering History, Language and Politics in the Maori-language Newspapers (2002) and in the great advances brought forward by digital technology which has seen an entire collection of these periodicals made available and searchable on the internet (http://www.nzdl.org). Many of the major archival institutions in this country including the National Library and the Alexander Turnbull Library have been leading the way in digitising important collections of historical manuscript material. The McLean collection is an invaluable source of research with its accompanying images, translations, summaries and other useful tools to researchers.

Many important works not only of English language translation but interpretation, annotation and historical context have been produced including important works by Ngai Tahu scholar Te Maire Tau (2003; 2011a), Ngati Porou scholar Tamati Reedy (1993; 1997), and the work of Pakeha scholar Margaret Orbell (1978; 1991; 2002) and Ngati Maniapoto scholar Bruce Biggs (1952; 1960; 1964). Further recent work by Te Ati Awa scholar Alice Te Punga Somerville examines articulations of Maori as Pacific people and Pacific people in Aotearoa (2012).

Much of this work intercepts and intersects at different points of engagement and spill over into other disciplines and fields. Such work challenges us to rethink and perhaps even rebuild the divisions between what we may understand to be disparate fields of study. Working between the boundaries of the academic disciplines of history, literary studies, Maori studies and linguistics is an appropriate place to position this thesis.

Finally, from the corners of this whare whakairo I look to the poupou who remain firmly in their space intellectually, culturally and spiritually waiting for more of their descendents to come and reconnect with the place and space of the whare. Ka whakairihia enei korero ki nga pakitara o te whare.

Kati. Kua tau. 


\section{Appendices}

\section{Tangi tuatahi na Rakapa Kahoki}

Te Tangi Arakapa Kahoki mo tona waea mo te Kuini Te Rangitopeora

E Horo, tunoa i te ngana o Rangawenua te wa

ka tika ai, te tira i to makau he tao

nga wakatau tau taringa ai o tuakana

to koutou whaka ko tera e rere atu

ra ma te marama koe tango ki te

rangi Ruku atu e Kui te ia no Raukawa

e kore koe e witi ki rawahi, takiritia

atu te haere ki wawe køe koutou te

tae ki te au Pouri, tena ra e koro

ma taku ware wakairo $i$, i hanga

nei e koutou, na Rongotakawiu turaki

ki raro e tangi tiari maira te tai o Aka

piti hoki kau mai nei a Matene ki te

kainga kaore ra he moke tangata tena ka

riro i te heke o Ngatitoa te hoki mai nei

te hau ki te ao ei

(Te Rauparaha 18?: unpaginated). 


\section{Tangi tuarua na Rakapa Kahoki}

Tangi tua rua tenei mo te Kuini Topeora na tana kotiro

E kimi ana au, kei wea te ara i nga

ro ai a Topeora, tena kataha ki te

Hauauru he noho i kona kia tangi au ki

a koe, ma konei, taua ki te maunga

Huka, e tu maira kei takahia

koe te ia no Whaikato e pai ana

kia matakitakina koe te rau o te iwi

mo ngatahua, ngaro i to papa uta ina

atu ra ki te ihu o nga wakataurua

tahuri mai nei to kanohi ki te

ware tonga ki nga paenga, riri

ki to tungane turia ai i te awa

tea ka hinga te Pakeha he waka

mutunga mahi te iwi ka ngaro nei e

(Te Rauparaha 18?: unpaginated). 


\section{References}

\section{Primary texts}

Te Rauparaha, Tamihana, 18?. ‘He Pukapuka Tataku Tenei I Nga Mahi a Te Rauparaha Nui, O Tona Itinga Kaumatua Noa/History of Te Rauparaha: Written by His Son Tamihana Te Rauparaha, at his Father's Dictation' (GNZMMSS 27). George Grey Special Collections, Auckland Public Library.

Te Whiwhi, Henare Matene, 1852. 'Ko te Korero Tenei o Maui/Genealogies and Legends' Written by the Chief Matene Te Whiwhi in 1852 From the Dictation of the Chief Te Rangihaeata or Mokau (GNZMMSS 46). George Grey Special Collections, Auckland Public Library.

\section{$\underline{\text { Secondary texts }}$}

Unpublished sources

Bass, John, 1918. Letter from the Chief Librarian, Auckland Public Library to The Town Clerk. 11 October.

Curnow, Jenifer, 1983. Wiremu Maihi Te Rangikaheke: His Life and Work. Unpublished MA Thesis, University of Auckland.

Gibbons, Peter, 1992. "Going Native": A Case Study of Cultural Appropriation in a Settler Society, with Particular Reference to the Activities of Johannes Andersen in New Zealand During the First Half of the Twentieth Century. 3 vols, Unpublished Dphil Thesis, Waikato University.

Graham, George, 1914a. Letter to The Chief Librarian, Auckland Public Library. 6 November. 
1914b. Letter to The Chief Librarian, Auckland Public Library.

19 November.

1915. Letter to The Chief Librarian, Auckland Public Library. 19 January.

1918. Letter to The Chief Librarian, Auckland Public Library. 18 August.

Grey, George, 14 July 1848. Letter to Gordon Gairdner. GRE/B99/6B/11-12. University of Durham Library.

19 May 1851. Letter to Reverend Lancelot Threlkeld. Threlkeld Papers, 1815-1862. ML A382. ML, SLNSW, Sydney.

Higgins, Rawinia, 2004. He Tānga Ngutu, He Tūhoetanga Te Mana Motuhake o te Tā Moko Wāhine: The Identity Politics of Moko Kauae. Unpublished PhD Thesis, University of Otago.

2013. Personal Communication. 3 August.

Hilliard, Chris, 1997. Island Stories: The Writing of New Zealand History 1920-1940. Unpublished MA Thesis, University of Auckland.

Jenkins, Kuni, 1991. Te Ihi, Te Wehi O Te Tuhi: Print Literacy From 1814-1855: Literacy, Power, and Colonisation. Unpublished MA Thesis, University of Auckland.

Ka'ai-Mahuta, Rachael Te Āwhina, 2010. He Kupu Tuku Iho Mō Tēnei Reanga: A Critical Analysis of Waiata and Haka as Commentaries and Archives of Māori Political History. Unpublished PhD Thesis, Auckland University of Technology.

Kapiti Island Public Reserve Act (1897). New Zealand Government. 
Loader, Arini, 2008. Haere mai me Tuhituhi he Pukapuka: Muri Iho ka Whawhai ai Tātou: Reading Te Rangikāheke. Unpublished MA Thesis, Victoria University of Wellington.

Morgan, Rewa, 2010. Oral History and Biography: The Oral Accounts of Te Rauparaha. Unpublished Honours Dissertation, University of Auckland.

Ngata, Apirana, 1923. Letter to The Chief Librarian, Auckland Public Library.

O'Carroll, Acushla Deanne, 2009. Haka and Hula Representations in Tourism. Unpublished MA Thesis, Victoria University of Wellington.

Otaki Maori Land Court Minute book, 30 October 1879.

Royal, Te Ahukaramū Charles, 1998. Te Whare Tapere: Towards a Model for Māori Performance Art. Unpublished PhD Thesis, Victoria University of Wellington.

Smith, Ailsa Lorraine, 2001. Taranaki Waiata Tangi and Feelings for Place. Unpublished PhD Thesis, Lincoln University.

Smith, Takirirangi, 2007. Whakapapa Korero, Tangata Whenua and Turangawaewae: A Case Study of the Colonisation of Indigenous Knowledge. Unpublished PhD Thesis, University of Auckland. 2012. Personal communication. 13 July.

Sutherland, Yvonne, 2007. Nineteenth Century Māori Letters of Emotion: Orality, Literacy and Context. Unpublished PhD Thesis, The University of Auckland.

Temara, Pou, 1991. Te Ahua o te Kupu Whakaari: The Nature of Prophetic Sayings. Unpublished Master of Arts Thesis, Victoria University of Wellington. 


\section{Published sources}

Adds, Peter, 2012. E kore au e ngaro: ancestral connections to the Pacific. Tangata O Le Moana: New Zealand and the People of the Pacific. Sean Mallon, Kolokesa Māhina-Tuai and Damon Salesa (eds.). Wellington: Te Papa Press, pp. 17-35.

Alpers, Antony, 1964. Maori Myths and Tribal Legends. Auckland: Longman Paul.

Ballara, Angela, 1990. Te Rangihaeata. In The Dictionary of New Zealand Biography, Vol. 1. Wellington: Allen and Unwin and the Department of Internal Affairs, pp. $488-491$.

2003. Taua: 'Musket Wars', 'Land Wars' or Tikanga?: Warfare in Māori Society in the Early Nineteenth Century. Auckland: Penguin.

Bernheimer, Charles (ed.), 1995. Comparative Literature in the Age of Multiculturalism. Baltimore: The Johns Hopkins University Press.

Best, Elsdon, 1905. Maori Eschatology: The Whare Potae (House of Mourning) and its Lore; Being a Description of Many Customs, Beliefs, Superstitions, Rites, \& c., Pertaining to Death and Burial Among the Maori People As Also Some Account of Native Belief in a Spiritual World. Transactions of the New Zealand Institute. 38, pp. 148-239.

1924. The Maori. Volume I. Wellington: Board of Maori Ethnological Research for the Author and on behalf of the Polynesian Society. 1976 reprint. The Maori Canoe: An Account of the Various Types of Vessels Used by the Maori of New Zealand in Former Times, with Some Description of Those of the Isles of the Pacific, and a Brief Account of the Peopling of New Zealand. Wellington: Government Printer.

Biggs, Bruce, 1952. The translation and publishing of Maori material in the Auckland Public Library. The Journal of the Polynesian Society 61: 177-191. 
1960. Maori Marriage: An Essay in Reconstruction. Wellington:

Polynesian Society.

1964. The oral literature of the Polynesians. Te Ao Hou. No 49. pp. $23-15 ; 42-47$.

Binney, Judith, 1987. Maori oral narratives, Pakeha written texts: two forms of telling history. New Zealand Journal of History 21(1): 16-28.

Bishop, Gavin, 2004. Taming the Sun: Four Maori Myths. Auckland: Random House.

Bleek, W. H. I., 1858. The Library of His Excellency Sir George Grey, K. C. B. Philology. London: Trubner and Co.

1867. The Library of His Excellency Sir George Grey Presented by Him to the South African Public Library. Cape Town and Port Elizabeth: J. C. Juta.

Brooks, Lisa, 2008. The Common Pot: The Recovery of Native Space in the Northeast. Minneapolis: University of Minnesota Press.

Buck, Peter, 1950. The Coming of the Maori, 1958 reprint. Wellington: Maori Purposes Fund Board and Whitcombe and Tombs.

Buick, T. Lindsay, 1911. An Old New Zealander, or, Te Rauparaha, the Napoleon of the South. London: Whitcombe and Tombs.

Burns, Patricia, 1980. Te Rauparaha; A New Perspective. Wellington: Reed.

Butler, Peter (ed.), 1980. Life and Times of Te Rauparaha by his Son Tamihana Te Rauparaha. Martinborough: Alister Taylor.

Carkeek, W. W., 2004. The Kapiti Coast: Maori History and Place Names of the Paekakariki-Otaki District. Auckland: Reed. 
Collins, Hēni, 2010. Ka Mate Ka Ora!; The Spirit of Te Rauparaha. Wellington: Steele Roberts.

Copland, R. A., 1975. Early poetry. New Zealand's Nature Heritage 6(85): 2357-2363.

Cosgrove, D. E., 1998. Social Formation and Symbolic Landscape. Wisconsin: University of Wisconsin Press.

Cowan, James, 1930a. The Maori: Yesterday and Today. Christchurch: Whitcombe and Tombs.

1930b. Pictures of Old New Zealand. Auckland: Whitcombe and Tombs.

Curnow, Allen (ed.), 1960. The Penguin Book of New Zealand Verse. Harmondsworth: Penguin.

Curnow, Jenifer, 1985. Wiremu Maihi Te Rangikaheke: his life and work. The Journal of the Polynesian Society 94(2): 97-147.

Davis, Charles Oliver B., 1855. Maori Mementos; Being a Series of Addresses, Presented by the Native People to His Excellency Sir George Grey. K. C. B., F. R. S. Governor and High Commissioner of the Cape of Good Hope and Late Governor of New Zealand; with Introductory Remarks and Explanatory Notes, to Which is Added a Small Collection of Laments, and C. Auckland: printed by Williamson and Wilson.

Deloria, Vine, 2003. God is Red: A Native View of Religion. Golden, Colo.: Fulcrum.

Dewes, Te Kapunga, 1975. The case for oral arts. In Michael King (ed.), Te Ao Hurihuri; The World Moves On: Aspects of Maoritanga. Wellington: Hicks Smith and Sons, pp. 55-85.

Finnegan, Ruth, 1988. Literacy and Orality: Studies in the Technology of Communication. Blackwell: Oxford. 
Garlick, Jennifer, 1998. Maori Language Publishing: Some Issues. Wellington: Huia.

Gibbons, Peter, 1986. A note on writing, identity, and colonisation in Aotearoa. Sites 13 (Spring): 32-8.

, 1998. Non-fiction. In Sturm, Terry (ed.), The Oxford Dictionary of New Zealand Literature in English. Oxford: Oxford University Press, pp. 31-118.

Gossage, Peter, 1975. How Maui-tiki-tiki-a-Taranga Found His Mother. Auckland: Lansdowne Press.

1980. How Maui Found His Father and the Magic Jawbone. Auckland: Lansdowne Press.

1982. How Maui Slowed the Sun: Te Hopu a Maaui i a te Raa. Auckland: Lansdowne Press.

1985. How Maui Defied the Goddess of Death: Te Taki a Maaui i a Hine-nui-te-poo. Auckland: Lansdowne Press.

1990. The Fish of Maui: Te Ika a Maaui. Auckland: Ashton Scholastic. 2005. How Maui Found the Secret of Fire. Auckland: Reed.

Grey, George, 1853. Ko nga Moteatea me nga Hakirara o nga Maori. Wellington: Robert Stokes.

1854. Ko nga Mahinga a nga Tupuna Maori. London: George Willis. 1855. Polynesian Mythology and Ancient Traditional History of the New Zealand Race, as Furnished by Their Priests and Chiefs. London: John Murray. 1857a. Ko nga Waiata Maori. Cape Town: Pike's Machine Printing Office. 
1857b, Ko nga Whakapepeha me nga Whakaahuareka a nga Tipuna o Aotearoa. Cape Town: Saul Solomon and Co., Steam Printing Office.

1885. Polynesian Mythology and Ancient Traditional History of the New Zealand Race, as Furnished by Their Priests and Chiefs. Auckland: H. Brett. $2^{\text {nd }}$ edn.

1928. Nga Mahi a nga Tupuna. New Plymouth: T. Avery. $3^{\text {rd }}$ edn.

Griffith, Penny, Ross Harvey and Keith Maslen (eds.), 1997. Book and Print in New Zealand: A Guide to Print Culture in Aotearoa. Wellington: Victoria University Press.

Griffith, Penny, Peter Hughes and Alan Loney (eds.), 2000. A Book in the Hand: Essays on the History of the Book in New Zealand. Auckland: Auckland University Press.

Haami, Bradford, 2004. Pūtea Whakairo: Maori and the Written Word. Wellington: Huia.

Harlow, R. B. and A. H. F. Thornton, 1986. A Name and Word Index to Nga Moteatea. Dunedin: University of Otago Press.

Hereniko, Vilsoni and David Hanlon, 1999. An interview with Albert Wendt. In Vilsoni Hereniko and Rob Wilson (eds.), Inside Out: Literature, Cultural Politics and Identity in the New Pacific. Lanham: Rowman and Littlefield, pp. 85-103.

Higgins, Rawinia and John C. Moorfield, 2004. Tangihanga - death customs. In Tānia M., John C. Moorfield, Michael P. J. Reilly and Sharon Mosley (eds.), Ki Te Whaiao: An Introduction to Māori Culture and Society. Auckland: Pearson Longman, pp. 85-90.

Hohepa, Pat, 1978. Maori and Pakeha: the one-people myth. In Michael King (ed.), Tihe Mauri Ora; Aspects of Maoritanga. Wellington: Methuen, pp. 98-111. 
Holland, S. G., 1950. Legislators' tributes. The Journal of the Polynesian Society 59(4): 319-334.

Hviding, Edvard, 2003. Between knowledges: Pacific studies and academic disciplines. The Contemporary Pacific 15(1): 43-73.

Hyland, Queenie Rikihana, 2003. Pakiwaitara: Illustrated Maori Myths and Legends. Auckland: Reed.

Jones, Pei Te Hurinui, 1961. Puhiwāhine: Maori Poetess. Christchurch: Pegasus Press.

Justice, Daniel, 2006a. "Not just shoveling smoke: indigenous literary nationalism and the rhetorics of recognition", a paper delivered at the conference Native American Literature: Nationalism and beyond, Institute of Native American Studies, University of Georgia, Athens, April 21.

2006b. Our Fire Survives the Storm: A Cherokee Literary History. Minneapolis: University of Minnesota Press.

Kaa, Hirini, 2012. Sex, sin and salvation: Māori morality through a Christian lens. Te Pouhere Kōrero 6: Māori History, Māori People. Wellington: Te Pouhere Kōrero. pp. 27-34.

Ka'ai, Tānia and Rawinia Higgins, 2004. Te ao Maori; Maori world view. In Ka'ai, Tānia, John C. Moorfield, Michael P. J. Reilly, and Sharon Mosley (eds.), Ki te Whaiao: An Introduction to Maori Culture and Society. Auckland: Pearson Education, pp. 13-25.

Kahukiwa, Robyn and Patricia Grace, 1991. Wahine Toa: Women of Maori Myth. Auckland: Viking Pacific.

Kapiti Hono Tatai Hono. 2007. Documentary produced by Libby Hakaraia and Bryn Evans. Blue Bach Productions/Bravestar. http://www.filmarchive.org.nz/the- 
catalogue/media/kapiti-hono-tatai-hono-my-island-my-home$\underline{\text { f99827?option }=\text { com_events\&task=view_detail\&agid }=2025}$.

Karetu, Sam (Tīmoti), 1975. Language and protocol of the marae. In Michael King (ed.), Te Ao Hurihuri: The World Moves On: Aspects of Maoritanga. Wellington: Hicks Smith and Sons, pp. 35-54.

1993. Haka! The Dance of a Noble People. Auckland: Reed.

Kerr, Donald Jackson, 2006. Amassing Treasures For All Times: Sir George Grey, Colonial Bookman and Collector. Delaware and Dunedin: Oak Knoll Press and Otago University Press.

Kerr, Elizabeth, 1994. Women composers in New Zealand in the $19^{\text {th }}$ and $20^{\text {th }}$ centuries - An ancient culture and a "young country"? Contemporary Music Review 11(1 \& 2): 325-332.

Lee, Jenny, 1985. Nga Mahi a Ringa. Tu Tangata. Issue 22, pp. 24-27. 1986a. More Early Maori Letters. Tu Tangata. Issue 30, pp. 54-55. 1986b. Another Early Letter from Ruta Te Rauparaha to Sir George and Lady Eliza Grey. Tu Tangata. Issue 32, pp. 58-59.

McGregor, John, 1893. Ko nga Waiata Maori: Na te Maori o Waikato e Tuhituhi, Pepuere, 1864. Akarana: Na Hone Henare Piira i ta.

McKinnon, Malcolm (ed.) with Barry Bradley and Russell Kirkpatrick, 1997. New Zealand Historical Atlas: Ko Papatuanuku e Takoto Nei. Auckland: David Bateman in association with Historical Branch, Department of Internal Affairs: Te Tari Taiwhenua.

McLean, Mervyn and Margaret Orbell, 1990. Traditional Songs of the Maori. Auckland: Auckland University Press. 
McRae, Jane, 1997. Transitions. In Penny Griffith, Ross Harvey and Keith Maslen (eds.), Book and Print Culture in New Zealand: A Guide to Print Culture in Aotearoa. Wellington: Victoria University Press, pp. 17-43.

1998. Maori literature: a survey. In Terry Sturm (ed.), The Oxford History of New Zealand Literature in English. Oxford: Oxford University Press, pp. 1-30.

2000. Maori oral tradition meets the book. In Griffith, Penny, Peter Hughes and Alan Loney (eds.), A Book in the Hand: Essays on the History of the Book in New Zealand. Auckland: Auckland University Press, pp. 1-16.

2002. 'E manu, tena koe!' 'O bird, greetings to you': the oral tradition in newspaper writing. In Curnow, Jenifer, Ngapare Hopa and Jane McRae (eds.), Rere Atu, Taku Manu!: Discovering History, Language and Politics in the Maori-language Newspapers. Auckland: Auckland University Press, pp. 42-59. 2004. Ngā tuhituhinga reo Maori: literature in Maori. In Tānia Ka'ai, John C. Moorfield, Michael P. J. Reilly and Sharon Mosley (eds.), Ki Te Whaiao: An Introduction to Maori Culture and Society. Auckland: Pearson Education, pp. 133-138.

McRae, Jane and Hēni Jacob, 2011. Ngā Moteatea: An Introduction: He Kupu Arataki. Auckland: Auckland University Press.

Macdonald, Charlotte, Merimeri Penfold and Bridget Williams, 1991. The Book of New Zealand Women: Ko Kui Ma te Kaupapa. Wellington: Bridget Williams Books.

Maclean, Chris, 1999. Kapiti. Wellington: Whitcombe Press with the assistance of the Historical Branch, Department of Internal Affairs.

Mahuika, Nepia, 2009. Revitalizing Te Ika a Maui: Maori migration and the nation. New Zealand Journal of History 43(2): 133-149. 
2010. Kōrero tuku iho: our gift and our responsibility. Te Pouhere Kōrero 4; Maori History, Maori People. Wellington: Te Pouhere Kōrero. pp. 24-40.

Markham, E., 1963. New Zealand or Recollections of it. Wellington: Government Printer.

Mead, S. M., 1969. Imagery, symbolism and social values in Maori chants. The Journal of the Polynesian Society 78(3): 378-404.

Mead, Hirini Moko and Neil Grove, 2001. Ngā Pèpeha a ngà Tìpuna: The Sayings of the Ancestors. Wellington: Victoria University Press.

van Meijl, Toon, 1996. Historicising Maoritanga: colonial ethnography and the reification of Maori traditions. The Journal of the Polynesian Society 105(3): 311-346.

Melbourne, Hirini, 1991. Whare whakairo: Māori 'literary' traditions. In G. McGregor, and Mark Williams (eds.), Dirty Silence: Aspects of Language and Literature in New Zealand: Essays Arising from the University of Waikato Winter Lecture Series, 1990. Auckland: Oxford University Press, pp. 129-141.

Meredith, Paul and Alice Te Punga Somerville, 2010/11. Kia rongo mai koutou ki taku whakaaro: Maori voices in the Alexander Turnbull Library. Turnbull Library Record. pp. 96-105.

Mikaere, Annie, 1994. Māori women: caught in the contradictions of a colonised reality. Waikato Law Review 2: 125-150.

Mitcalfe, Barry, 1961. Poetry of the Maori: Translations. Hamilton: Paul's Book Arcade.

Mitchell, Hilary and John, 2004. Te Tau Ihu o Te Waka: A History of Maori of Nelson and Marlborough. Volume I: Te Tangata me te Whenua: The People and the Land. Wellington: Huia in association with Wakatu Incorporation. 
2007. Te Tau Ihu o Te Waka: A History of Maori of Nelson and Marlborough. Volume II: Te Ara Hou: The New Society. Wellington: Huia in association with Wakatu Incorporation.

Muller, John P. and William J. Richardson (eds.), 1988. The Purloined Poe: Lacan, Derrida and Psychoanalytic Reading. Baltimore: The Johns Hopkins University Press.

Ngata, A. T., 1928. Nga Moteatea: He Maramara Rere no nga Waka Maha. Hastings: Te Poari Whakapapa (The Board of Maori Ethnological Research). Printed by E. S. Cliff and Co.

1940. The Maori and printed matter. In R. A. Mckay (ed.), A History of Printing in New Zealand, 1830-1940. Wellington: Wellington Club of Printing House Craftsmen, pp. 48-49.

1950. The Io cult: early migration puzzle of the canoes. The Journal of the Polynesian Society 59(4): 335-346.

1961. Nga Moteatea: He Maramara Rere no nga Waka Maha. Part II. Wellington: Reed for The Polynesian Society.

1972. Nga Moteatea: He Maramara Rere no nga Waka Maha. Part I. Wellington: Reed for The Polynesian Society.

Ngata, A. T., and Pei Te Hurinui Jones, 2006. Nga Moteatea: He Maramara Rere No nga Waka Maha. Part III. Auckland: Auckland University Press.

Nicole, Robert, 2001. The Word, the Pen, and the Pistol: Literature and Power in Tahiti. New York: State University of New York Press.

O’Leary, John, 2008. Sir George Edward Grey, 1812 - 1898. Kōtare 2008, Special Issue Essays in New Zealand Literary Biography Series Two: 'Early Male Prose Writers'. Wellington: Victoria University of Wellington. 7(2): 19-26. 
Oliver, Stephen, 1990a. Te Rauparaha. In The Dictionary of New Zealand Biography, Vol. 1. Wellington: Allen and Unwin and the Department of Internal Affairs, pp. 504-507.

1990b. Te Rauparaha, Tamihana. In The Dictionary of New Zealand Biography, Vol. 1. Wellington: Allen and Unwin and the Department of Internal Affairs, pp. 507-508.

Oliver, W. H., 1990. Te Whiwhi, Henare Matene. In The Dictionary of New Zealand Biography, Vol. 1. Wellington: Allen and Unwin and the Department of Internal Affairs, pp. 528-529.

Orbell, Margaret, 1968. Two manuscripts of Te Rangikaheke. Te Ao Hou (62): 8-12. 1978. Maori Poetry: An Introductory Anthology. Auckland: Heinemann Educational Books.

1985. Hawaiki: A New Approach to Maori Tradition. Christchurch: The University of Canterbury. 1991. Waiata: Maori Songs in History. Auckland: Reed. 2002. He Reta Ki Te Maunga: Letters to the Mountain: Māori Letters to the Editor, 1898-1905. Auckland: Reed.

Ortiz, Simon J., 2003. Song, poetry, and language - expression and perception. In MariJo Moore (ed.), Genocide of the Mind; New Native American Writing. New York: Nation Books, pp. 105-118.

Parr, C. J., 1961. A mission library: printed attempts to instruct the Maori. The Journal of the Polynesian Society 70(4): 429-450.

Paterson, Lachy, 2006. Colonial Discourses: Niupepa Māori, 1855-1863. Dunedin: University of Otago Press. 
Peyer, Bernd, 1997. The Tutor'd Mind: Indian Writers in Antebellum America. Amherst: University of Massachusetts Press.

Pohatu, Warren, 2000. Traditional Maori Legends: Nga Tai Korero. Auckland: Reed.

Ramsden, Eric, 1948. Sir Apirana Ngata and Maori Culture. Wellington: Reed.

Ramsden, Irihapeti, 1993. Borders and frontiers. In Alex Calder (ed.), The Writing of New Zealand: Inventions and Identities. Auckland: Reed, pp. 236-244.

Rangihau, John, 1992. Being Maori. In Michael King (ed.), Te Ao Hurihuri; Aspects of Maoritanga. Auckland: Reed, pp. 183-190.

Reed, A. W., 2001. Illustrated Māori Place Names. Auckland: Reed.

Reedy, Anaru, 1993. Ngā Kōrero a Mohi Ruatapu Tohunga Rongonui o Ngāti Porou: The Writings of Mohi Ruatapu: Translated, Edited and Annotated by Anaru Reedy. Christchurch: Canterbury University Press. 1997. Ngā Kōrero a Pita Kāpiti: The Teachings of Pita Kāpiti: Translated, Edited and Annotated by Anaru Reedy. Christchurch: Canterbury University Press.

Reilly, Michael P. J., 1990. White, John. In The Dictionary of New Zealand Biography, Vol. 1. Wellington: Allen and Unwin and the Department of Internal Affairs, pp. 587-589.

Royal, Te Ahukaramū Charles, 1992. Te Haurapa: An Introduction to Researching Tribal Histories and Traditions. Wellington: Bridget Williams Books in association with the Historical Branch, Department of Internal Affairs.

1994. Kāti Au I Konei: He Kohikohinga i ngā Waiata a Ngati Toarangatira, a Ngati Raukawa. Wellington: Huia.

Saussy, Haun (ed.), 2006. Comparative Literature in an Age of Globalization. Baltimore: The Johns Hopkins University Press. 
Shepherd, Winsome, 1990. Travers, William Thomas Locke. In The Dictionary of New Zealand Biography, Vol. 1. Wellington: Allen and Unwin and the Department of Internal Affairs, pp. 547-548.

Shortland, Edward, 1854. Traditions and Superstitions of the New Zealanders: With Illustrations of Their Manners and Customs. London: Longman, Brown, Green, and Longmans.

Simmons, D. R., 1966. The sources of Sir George Grey's Nga Mahi a Nga Tupuna. The Journal of the Polynesian Society 75(2): 177-188.

Slane, Chris and Robert Sullivan, 1996. Maui: Legends of the Outcast: A Graphic Novel. Auckland: Godwit Publishing.

Smith, Linda Tuhiwai, 1999. Decolonizing Methodologies: Research and Indigenous Peoples. Dunedin, London and New York: University of Otago Press and Zed Books.

Sorrenson, M. P. K., 1986. Na To Hoa Aroha: From Your Dear Friend: The Correspondence Between Sir Apirana Ngata and Sir Peter Buck 1925-50. Auckland: Auckland University Press. Volumes I, II and III.

1996. Apirana Turupa Ngata. In The Dictionary of New Zealand Biography, Vol. 3. Auckland: Auckland University Press with Bridget Williams Books, pp. 359-63.

Sparks, Teremoana and W. H. Oliver, 1990a. Topeora, Rangi Kuini Wikitoria. In The Dictionary of New Zealand Biography, Vol. 1. Wellington: Allen and Unwin and the Department of Internal Affairs, pp. 546-547.

1990b. Waitohi. In The Dictionary of New Zealand Biography, Vol. 1. Wellington: Allen and Unwin and the Department of Internal Affairs, pp. 571. 
Stack, J. W., 1893. Kaiapohia: The Story of a Seige. Christchurch: Whitcombe and Tombs.

Stafford, Jane and Mark Williams, 2006. Maoriland: New Zealand Literature 1872-1914. Wellington: Victoria University Press.

2008. Apirana Turupa Ngata, 1874-1950. Kōtare 7(2): 123-131.

Street, Brian, 1993. Cross-Cultural Approaches to Literacy. New York: Cambridge University Press.

Sullivan, Robert, 2002. Weaving Earth and Sky: Myths and Legends of Aotearoa. Auckland: Random House.

Tau, Rawiri Te Maire, 2001a. The death of knowledge: ghosts on the plains. New Zealand Journal of History 35(2): 131-152.

2001b. Matauranga Maori as an epistemology. In Sharp, Andrew and Paul McHugh (eds.), Histories of Power and Loss: Uses of the Past - a New Zealand Commentary. Wellington: Bridget Williams Books, pp. 61-73.

2003. Ngā Pikitūroa o Ngāi Tahu: The Oral Traditions of Ngāi Tahu. Dunedin: University of Otago Press.

2011a. I Whānau Au Ki Kaiapoi: The Story of Natanahira Waruwarutu as Recorded by Thomas Green. Dunedin: Otago University Press.

2011b. Tirohia atu nei ka whetū rangitia, minding the past. Te Pouhere Kōrero 5; Maori History, Maori People. Wellington: Te Pouhere Kōrero.

2012. Kākāriki, pōwhaitere: the beauty of the canoe traditions. In Danny Keenan (ed.), Huia Histories of Māori: Ngā Tāhuhu Kōrero. Wellington: Huia, pp. 12-31. 
Taylor, Richard, 1855. Te Ika a Maui or New Zealand and It's Inhabitants, Illustrating the Origin, Manners, Customs, Mythology, Religion, Rites, Songs, Proverbs, Fables and Language of the Natives Together With the Geology, Natural History, Productions, and Climate of the Country; Its State as Regards Christianity; Sketches of the Principal Chiefs and their Present Position; With a Map and Numerous Illustrations. London: Wertheim and Macintosh.

Te Punga Somerville, Alice, 2009. The historian who lost his memory: A story about stories. Te Pouhere Kōrero 3; Maori History, Maori People. Wellington: Te Pouhere Kōrero.

2012. Once Were Pacific: Māori Connections to Oceania. Minneapolis: University of Minnesota Press.

"The Tahiwis": historic 1930 recordings by Te Whānau Tahiwi. Atoll. Te Puna Mātauranga o Aotearoa/National Library of New Zealand. 1998.

Thornton, Agathe, 1987. Māori Oral Literature as Seen by a Classicist. Dunedin: University of Otago Press.

van Toorn, Penny, 2006. Writing Never Arrives Naked; Early Aboriginal Cultures of Writing in Australia. Canberra: Aboriginal Studies Press.

Travers, W. T. L., 1872a. Some chapters in the life and times of Te Rauparaha, chief of Ngatitoa. Transactions of the New Zealand Institute. Volume 5. 1872b. Some Chapters in the Life and Times of Te Rauparaha, Chief of Ngatitoa. Wellington: James Hughes (Printer).

Travers, W. T. L. and Rev J. W. Stack, 1906. The Stirring Times of Te Rauparaha (Chief of the Ngatitoa), also, The Sacking of Kaiapohia. Christchurch: Whitcombe and Tombs. 
Tremewan, Christine, 2002. Poetry in Te Waka Maori. In Curnow, Jenifer, Ngapare Hopa and Jane McRae (eds.), Rere Atu, Taku Manu!: Discovering History, Language and Politics in the Maori-Language Newspapers. Auckland: Auckland University Press, pp. 115-133.

Turnbull, M. and I. McLaren, 1964. The Land of New Zealand. Aberdeen: University Press of Aberdeen.

Unknown author, 1926. Honorific Terms, Sacerdotal Expressions, Personifications, etc., Met with in Maori Narrative. The Journal of the Polynesian Society 35(139): 239-241.

Wade, W., 1977. A Journey into the Northern Island of New Zealand. Christchurch: Capper Press.

Waikato-Tainui, 2010. He Mea Whakairo I Te Ngaakau: Designs of the Heart: A Compilation of Traditional Waiata. Waikato Institute of Technology, Te Kuratini o Waikato.

Wakefield, Edward Jerringham, 1845. Adventure in New Zealand, From 1839 to 1844: With Some Account of the Beginning of the British Colonization of the Islands. London: John Murray.

Walker, Ranginui, 1990. Ka Whawhai Tonu Matou: Struggle Without End. Auckland: Penguin. 1992. The relevance of Maori myth and tradition. In Michael King (ed.), Te Ao Hurihuri: Aspects of Maoritanga. Auckland: Reed, pp. 170-182. 2001. He Tipua: The Life and Times of Sir Āpirana Ngata. Auckland: Penguin.

Warrior, Robert Allen, 1995. Tribal Secrets: Recovering American Indian Intellectual Traditions. Minneapolis: University of Minnesota Press. 
Weaver, Jace, Craig S. Womack and Robert Warrior, 2006. American Indian Literary Nationalism. Albuequerque: University of New Mexico Press.

White, John, 1890. The Ancient History of the Maori, His Mythology and Traditions: Volume 6: Tainui. Wellington: Government Printer.

Williams, H. W., 1906. Maori matter at the Cape of Good Hope: some notes on the Grey collection in the Capetown Library. The Journal of the Polynesian Society 15(3): 175-180.

1908. He Whakatauki, he Titotito, he Pepeha. Gisborne: Te Rau Kahikatea.

1971. A Dictionary of the Maori Language. Wellington: Government Printer.

1975. A Bibliography of Printed Maori to 1900 and Supplement. Wellington: Government Printer.

Winitana, C., 1994. From Words to Wood. Mana, no. 6, Jul-Sep 1994.

Womack, Craig, 1999. Red on Red: Native American Literary Separatism. Minneapolis: University of Minnesota Press.

Womack, Craig S., Daniel Heath Justice and Christopher B. Teuton (eds.), 2008. Reasoning Together: The Native Critics Collective. Oklahoma: University of Oklahoma Press.

Wright, Harrison M., 1959. New Zealand, 1769-1840, Early Years of Western Contact. Cambridge,: Harvard University Press. 


\section{Electronic sources}

Anderson, Robyn and Keith Pickens, 1996. Rangahaua Whanui District Research Report 12: Wellington District: Port Nicholson, Hutt Valley, Porirua, Rangitikei, and Manawatu. Working Paper: First Release. Waitangi Tribunal Rangahaua Whanui

Series.http://www.waitangitribunal.govt.nz/doclibrary/public/researchwhanui/district/12/District12WellingtonDistrict.pdf.

Barthes, Roland, translated by Richard Howard, 1967. The death of the author. Aspen. (5 and 6). [Retrieved 17 March 2013.] Available from: http://www.ubu.com/aspen/aspen5and6/threeEssays.html\#barthes.

Byrnes, Giselle M., 2010. 'Smith, Stephenson Percy - Biography', from the Dictionary of New Zealand Biography. Te Ara - the Encyclopedia of New Zealand, updated 1-Sep-10 http://www.TeAra.govt.nz/en/biographies/2s33/1.

Graham, Edward Rahiri and Jenifer Curnow, 2010. 'Graham, George Samuel Biography', from the Dictionary of New Zealand Biography. Te Ara - the Encyclopedia of New Zealand, updated 1-Sep-10. http://www.TeAra.govt.nz/en/biographies/4g17/1.

Higgins, Rawinia and Paul Meredith, 2011. 'Tangihanga - death customs Traditional preparations for tangihanga', Te Ara - the Encyclopedia of New Zealand, updated 3-May-11 http://www.TeAra.govt.nz/en/tangihangadeath-customs $/ 3$.

Keane, Basil, 2009. 'Tāwhirimātea - the weather', Te Ara - the Encyclopedia of New Zealand, updated 2-Mar-09 http://www.TeAra.govt.nz/en/tawhirimatea-the-weather. 
McLintock, A. H. (ed.), 2009. 'Foundation', from An Encyclopaedia of New Zealand, originally published in 1966. Te Ara - the Encyclopedia of New Zealand, updated 23-Apr-09 http://www.TeAra.govt.nz/en/1966/royal-society.

Royal, Te Ahukaramū Charles, 2012a. 'Hawaiki', Te Ara - the Encyclopedia of New Zealand, updated 9-Nov-12 http://www.TeAra.govt.nz/en/hawaiki. 2012b. 'Waikato tribes - Waikato landmarks', Te Ara - the Encyclopedia of New Zealand, updated 22-Sep-12 http://www.TeAra.govt.nz/en/waikato-tribes/page-2.

Solomon, Oriwa Dene, 2003. Brief of Evidence in the Waitangi Tribunal. (WAI 785). $9 \quad$ June. $\quad$ http://www.ngatitoa.iwi.nz/wpcontent/uploads/PhotoGallery/2011/10/Oriwa-Solomon.pdf.

Swarbrick, Nancy, 2010. 'Waikato places - Waikato River', Te Ara - the Encyclopedia of New Zealand, updated 26-Nov-10 http://www.TeAra.govt.nz/en/waikatoplaces $/ 1$.

Tau, Te Maire, 2009. 'Ngāi Tahu - Wars with Ngāti Toa', Te Ara - the Encyclopedia of New Zealand, updated 4-Mar-09 http:// www.TeAra.govt.nz/en/ngai-tahu/6.

Taonui, Rawiri, 2009a. 'Canoe traditions - Te Arawa and Tainui', Te Ara - the Encyclopedia of New Zealand, updated 4-Mar-09. http://www.TeAra.govt.nz/en/canoe-traditions/5.

2009b. 'Tapa whenua - naming places - Names from Polynesian mythology', Te Ara - the Encyclopedia of New Zealand, updated 22-Sep-12 http://www.TeAra.govt.nz/en/tapa-whenua-naming-places/page-2.

2009c. 'Canoe navigation - Ocean voyaging', Te Ara - the Encyclopedia of New Zealand, updated 4-Mar-09 http://www.TeAra.govt.nz/en/canoe-navigation/2. 
Tipene, Jillian, 2008. Seeking a research framework through an historical tribal manuscript. MAI Review. http://www.review.mai.ac.nz.

Traue, J. E., 2010. 'Buick, Thomas Lindsay - Biography', from the Dictionary of New Zealand Biography. Te Ara - the Encyclopedia of New Zealand, updated 1-Sep10 (b). http://www.TeAra.govt.nz/en/biographies/3b57/1.

Walker, Piripi, 2010. 'Parker, William Leonard - Biography', from the Dictionary of New Zealand Biography. Te Ara - the Encyclopedia of New Zealand, updated 1-Sep-10. http://www.TeAra.govt.nz/en/biographies/5p11/1.

http://collections.tepapa.govt.nz/theme.aspx?irn=1339.

http://kapitiislandnaturetours.co.nz/about-us/kaitiaki-o-kapiti-trust/.

http://www.nztopomaps.com/16437/Otaki-Forks/Wellington.

http://www.stuff.co.nz/dominion-post/news/local-papers/kapi-mananews/4320993/Descendant-of-Te-Rauparaha-traces-the-history-of-Poriruashaka . 